\title{
22. MELT, CRYSTAL, AND FLUID INCLUSIONS IN OLIVINE AND CLINOPYROXENE PHENOCRYSTS FROM THE SUBMARINE SHIELD STAGE HYALOCLASTITES OF GRAN CANARIA, SITES 953 AND $956^{1}$
}

\author{
Andrey A. Gurenko, ${ }^{2}$ Thor H. Hansteen, ${ }^{2}$ and Hans-Ulrich Schmincke ${ }^{2}$
}

\begin{abstract}
Miocene submarine basaltic hyaloclastites, lapillistones, and breccias drilled at Sites 953 and 956 contain relicts of olivine and fresh clinopyroxene phenocrysts with abundant primary melt, fluid, and crystal inclusions. Primary melt inclusions are represented by glassy (quenched glass \pm gas bubble/s) and multiphase (glass + daughter crystals \pm gas bubble/s) types. Fluid inclusions are composed of gas and liquid phases and are nearly pure $\mathrm{CO}_{2}$ in composition, as shown by low-temperature microthermometric studies. Melt and crystal inclusions and their host minerals were analyzed for major elements by electron microprobe and large ( $>60 \mu \mathrm{m}$ in size) representative melt inclusions by ion microprobe for trace elements and $\mathrm{H}_{2} \mathrm{O}$. Olivine phenocrysts from two basalt fragments are $\mathrm{Fo}_{80-89}$ and correspond to the entire range of olivine compositions known for the Miocene shield basalts on Gran Canaria. Clinopyroxene phenocrysts from basalt fragments and hyaloclastite matrix are characterized by a wide compositional spectrum of $\mathrm{Mg} /\left(\mathrm{Mg}+\mathrm{Fe}_{\text {tot }}\right)=0.74-0.90, \mathrm{Wo}_{37-47}, \mathrm{En}_{41-52}, \mathrm{Fs}_{6-15}$. Crystal inclusions are represented by olivine $\left(\mathrm{Fo}_{80-82}\right)$, clinopyroxene $\left(\mathrm{Mg} /\left(\mathrm{Mg}+\mathrm{Fe}_{\text {tot }}\right)=0.79-0.82, \mathrm{Wo}_{41-45}, \mathrm{En}_{44-48}, \mathrm{Fs}_{11}\right)$, plagioclase $\left(\mathrm{An}_{68-83}\right)$, high-Ti chrome spinel and titanomagnetite $\left(2.5-18.7 \mathrm{wt} \% \mathrm{TiO}_{2}, \mathrm{Mg} /\left(\mathrm{Mg}+\mathrm{Fe}^{2+}\right)=0.21-0.58\right.$, and $\left.\mathrm{Cr} /(\mathrm{Cr}+\mathrm{Al})=0.17-0.74\right)$, and ilmenite. Major element compositions of melt inclusions corrected for post-entrapment crystallization of olivine and clinopyroxene show a broad compositional spectrum ranging from quartz-normative tholeiitic to transitional basalts (46.3-54.4 wt\% $\mathrm{SiO}_{2}, 5.1-10.7 \mathrm{wt} \% \mathrm{MgO}, 1.3-3.5 \mathrm{wt} \% \mathrm{Na}_{2} \mathrm{O}$, and $0.7-1.9 \mathrm{wt} \% \mathrm{~K}_{2} \mathrm{O}$ ) and are enriched in incompatible trace and rare earth elements. We interpret this large compositional range as representing that of parental magmas, rather than being caused by crystallization of a single magma. Melt inclusions are enriched by light rare earth elements $\left[(\mathrm{La} / \mathrm{Sm})_{\mathrm{n}}=1.7-3.0\right]$ and depleted in heavy rare earth $\left[(\mathrm{Sm} / \mathrm{Yb})_{\mathrm{n}}=4.4-10.2\right]$ and high field strength elements $\left[(\mathrm{Zr} / \mathrm{Y})_{\mathrm{n}}=4.1-5.5\right]$. Because shallow level magma crystallization is unlikely to significantly change trace element ratios in the melt, we think that the observed discrepancy in $(\mathrm{La} /$ $\mathrm{Sm})_{\mathrm{n}}$ and $(\mathrm{Sm} / \mathrm{Yb})_{\mathrm{n}}$ ratios, and high $(\mathrm{Zr} / \mathrm{Y})_{\mathrm{n}}$ ratios resulted from the melting of a garnet-bearing mantle source.

Calculated parental magmas equilibrated with $\mathrm{Fo}_{90}$ represent a range from transitional to tholeiitic compositions (46.7-52.0 $\left.\mathrm{wt} \% \mathrm{SiO}_{2}\right)$ and are similar to olivine basalt-picrite $(11.2-18.0 \mathrm{wt} \% \mathrm{MgO})$. They crystallized over the range of temperatures from $1450^{\circ}$ to $1120^{\circ} \mathrm{C}$ and pressures from $<0.5$ to $8 \mathrm{kbar}$. Oxygen fugacity varied from the conditions corresponding to FMQ- 1 or WM-1 buffers during the early crystallization stage of parental magmas, to late-stage conditions of FMQ - NNO+1. Crystallization of magmas occurred in the presence of fluid of essentially $\mathrm{CO}_{2}$ composition.
\end{abstract}

\section{INTRODUCTION}

The volcaniclastic apron around Gran Canaria consists of sediments resulting from submarine volcanic activity during the seamount stage, explosive volcanic activity in shallow water, entry of lava flows, and pyroclastic flows generated on land into the sea, and products of erosion (Schmincke et al., 1995a; Schmincke, Weaver, Firth, et al., 1995b). The compositional evolution, growth, and mass wasting of Gran Canaria is reflected in sediments of the adjacent apron drilled at Sites 953 through 956.

The Miocene basaltic hyaloclastites, lapillistones, and breccias are described in detail by Schmincke and Segschneider (Chap. 12, this volume). All hyaloclastites are strongly altered but contain phenocrysts of clinopyroxene and, more rarely, olivine with abundant primary melt, crystal and fluid inclusions. Because of the strong posteruptive alteration, study of phenocryst-hosted inclusions is a promising approach to reconstruct the geochemical evolution of magmas formed during the Miocene seamount stage. We report here the first results of mineralogical and geochemical studies of glass, crystal, and fluid inclusions in olivine and clinopyroxene phenocrysts from the most primitive Miocene volcaniclastic rocks drilled at Sites 953 and 956. Low-temperature microthermometry of fluid inclusions, and

${ }^{1}$ Weaver, P.P.E., Schmincke, H.-U., Firth, J.V., and Duffield, W. (Eds.), 1998. Proc. ODP, Sci. Results, 157: College Station, TX (Ocean Drilling Program).

${ }^{2}$ GEOMAR Forschungszentrum, Wischhofstraße 1-3, D-24148 Kiel, Federal Republic of Germany. agurenko@geomar.de electron and ion microprobe analyses of melt, crystal inclusions, and their host minerals were used to reconstruct: (1) the composition of magma during the stage of phenocryst crystallization (major and trace elements, and $\mathrm{H}_{2} \mathrm{O}$ concentrations); (2) temperature, pressure, and redox conditions of phenocryst crystallization; and (3) composition of fluid that coexisted with the crystallizing magma. These data provide a quantitative basis for a discussion of the petrogenesis of the magmas parental to the volcaniclastic deposits of the seamount stage of Gran Canaria.

\section{STRATIGRAPHY, LITHOLOGY, AND SAMPLE SELECTION}

Drilling at Sites 953 through 956 concentrated on the volcanic apron north and south of Gran Canaria (Schmincke et al., 1995a, Schmincke, Weaver, Firth, et al., 1995b; Fig. 1). Site 953 is located $68 \mathrm{~km}$ northeast of Gran Canaria, $90 \mathrm{~km}$ west of Fuerteventura, and $98 \mathrm{~km}$ east of Tenerife. Drilling at Site 953 recovered a practically complete Quaternary to mid-Miocene 1159-m-thick section, in which the volcaniclastic rocks correspond closely to the lithostratigraphic subdivision of the volcanics exposed on Gran Canaria. The oldest volcaniclastic sediments of mid-Miocene age (Unit VII, Sections 157-953C-83R-4 through 103R-7, 969-1159 meters below sea floor [mbsf]; Fig. 2A) consist entirely of dark green hyaloclastite tuff, lapillistone, and breccia interbedded with fine-grained biogenic sediment (Shipboard Scientific Party, 1995a; Schmincke and Seg-

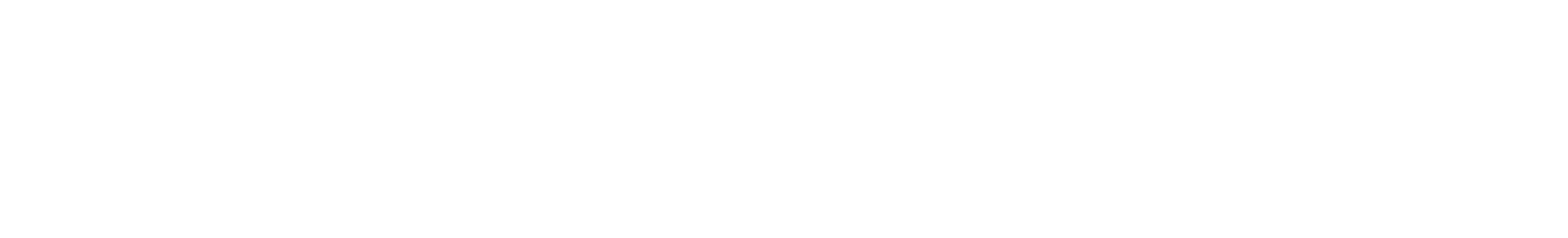


schneider, Chap. 12, this volume). Altered basaltic glass clasts, tachylite, fragments of crystalline basalt, crystals mostly represented by clinopyroxene, opaque minerals, rare plagioclase, and pseudomorphs of altered olivine are the dominant components. Lithic clasts of picrite basalts and basalt lapillistones usually contain phenocrysts of slightly altered olivine (Samples 157-953C-90R-5, 49-55 cm,

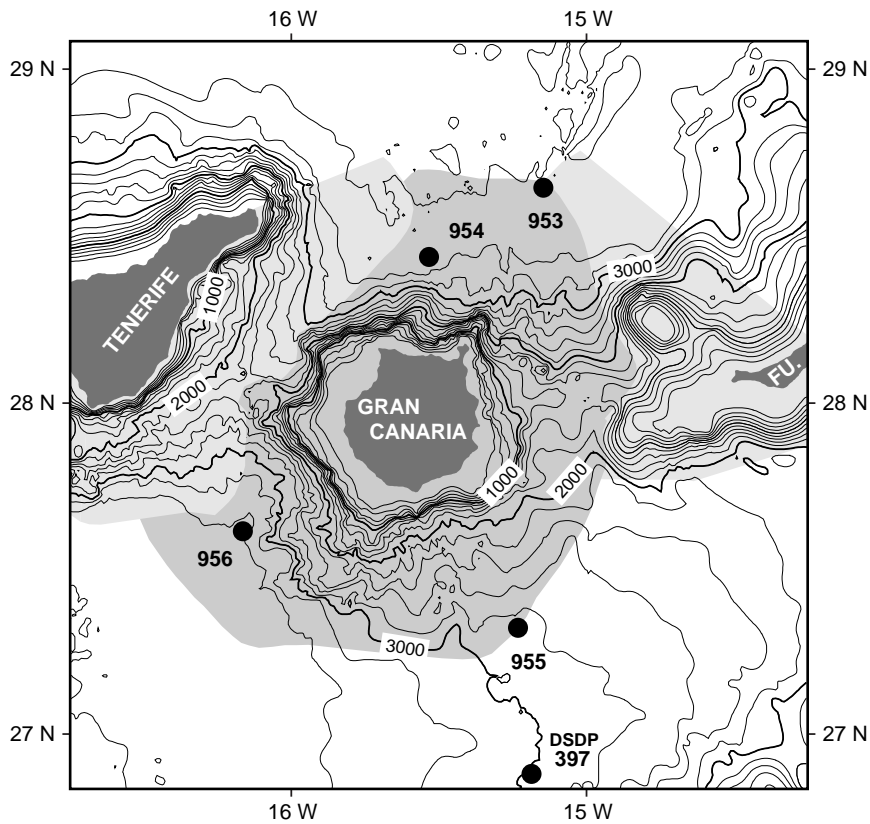

Figure 1. Schematic map showing locations of Site 953 through 956 in relation to the Canary Islands (after Funck, 1996). Shaded fields are seismically defined volcaniclastic aprons of Fuerteventura, Gran Canaria, and Tenerife.
93R-4, 20-22 cm, 93R-5, 13-27 cm, 93R-6, 45-55 cm, and 101R-5, $116-123 \mathrm{~cm}$ ). Unit VI (Sections 157-953C-75R-1 through 157953C-83R-3, 889-969 mbsf) consists mostly of thick to very thick bedded basaltic sandstone, lapillistone, and breccia interbedded with minor calcareous claystone and nannofossil mixed sedimentary rocks (Shipboard Scientific Party, 1995a). Dark green hyaloclastite tuffs occur in Cores 157-953C-77R through 83R and make up beds of several meters thickness (Schmincke and Segschneider, Chap. 12, this volume). They are composed mostly of angular vesicle-free to pumiceous mafic shards completely replaced by smectite.

At Site 956, drilled sedimentary succession ranges from Holocene to mid-Miocene age (Shipboard Scientific Party, 1995b). The oldest volcaniclastic sediments of mid-Miocene age (Unit V, Sections 157956B-43R-3 through 57R-1, 564-704 mbsf) consist mostly of massive to bedded epiclastic basaltic sandstone, lapillistone, breccia, and fine-grained hyaloclastite tuff with minor interbeds of nannofossil claystone with foraminifers (Fig. 2B). Fresh clinopyroxene phenocrysts and olivine pseudomorphs are common throughout the entire succession of volcaniclastic sediments drilled at Unit V. Relicts of fresh olivine are rare (Samples 157-956B-48R-2, 25-42 cm, and 56R-2, 89-103 cm), trace plagioclase phenocrysts were found in Samples 157-956B-44R-4, 110-124 cm, and 56R-3, 69-77 cm (Schmincke and Segschneider, Chap. 12, this volume).

We studied 10 samples of hyaloclastite tuffs containing basalt fragments lapillistones from Site 953 (Unit VI and VII) and three samples of hyaloclastite tuff with basaltic fragments from Site 956 (upper part of Unit V; Fig. 2A, B; Table 1). The main criterion for sample selection was the presence of olivine and clinopyroxene phenocrysts containing abundant primary melt, crystal, and fluid inclusions. Although clinopyroxene is present throughout all studied samples, fresh olivine was found only in Samples 157-953C-93R-5, 13$27 \mathrm{~cm}$, and 93R-6, 45-55 cm. Trace plagioclase phenocrysts are documented in Samples 157-956B-45R-3, 120-132 cm, and 45R-CC, 7$17 \mathrm{~cm}$.
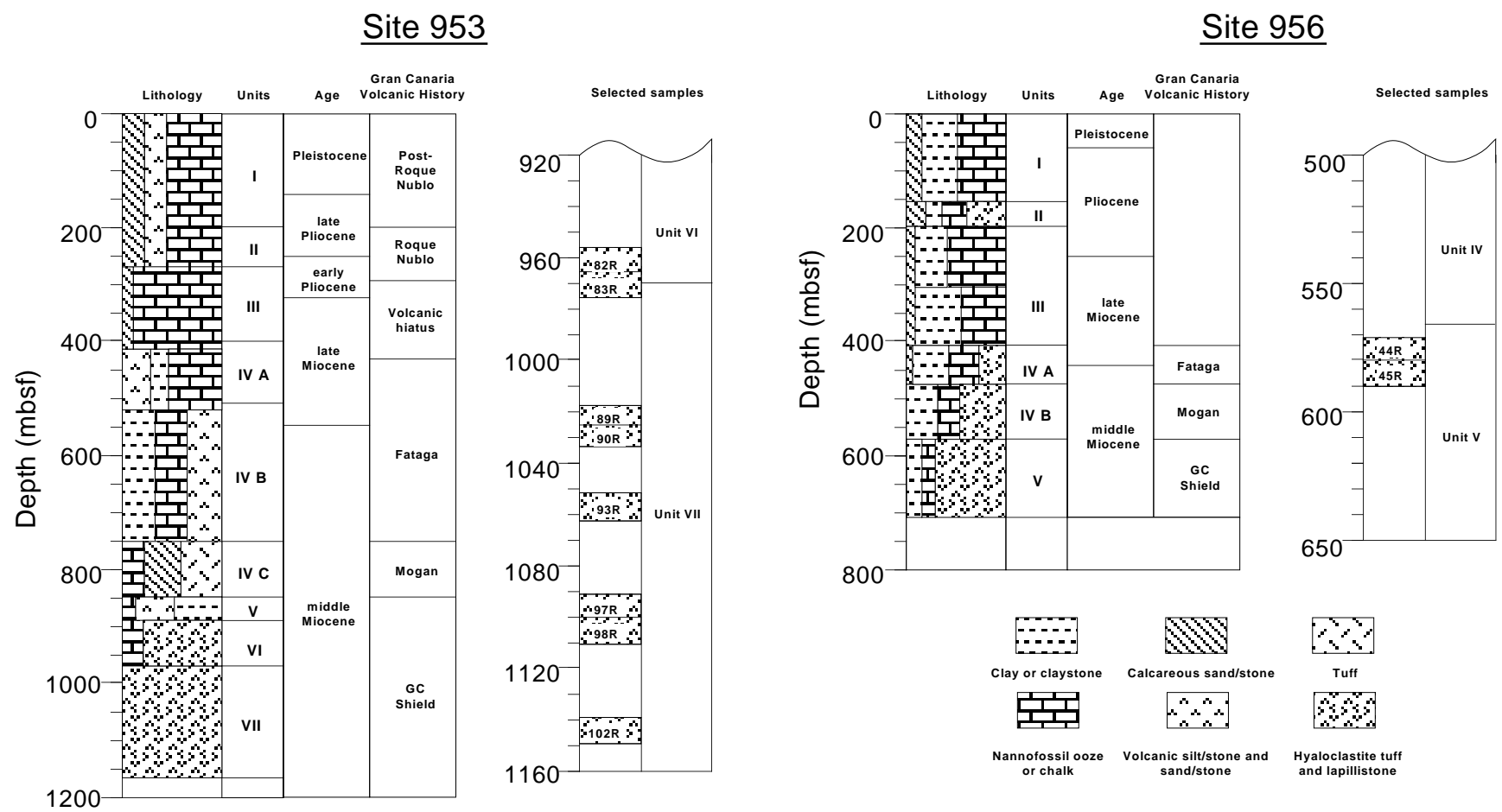

Figure 2. Summary diagrams for Sites 953 and 956, showing lithology, units, age, relationship to Gran Canaria volcanic history, and position of the selected samples. 


\section{ANALYTICAL METHODS \\ Electron Microprobe}

Major element analyses of minerals and glasses were carried out using a Cameca SX-50 electron probe at the GEOMAR Research Center (Kiel, Germany). Analytical conditions were accelerating voltage of $15 \mathrm{kV}$, beam current $10-20 \mathrm{nA}$, and peak counting time 10 $\mathrm{s}$. Analysis of minerals was performed with a beam size of $1-2 \mu \mathrm{m}$, and in scanning mode with a raster of $10 \mu \mathrm{m} \times 12 \mu \mathrm{m}$ for glasses. Cameca synthetic oxides ( $\mathrm{NiO}, \mathrm{Cr}_{2} \mathrm{O}_{3}$ ), basalt glass USNM 111240/ 52, clinopyroxene USNM 122142, plagioclase USNM 115900, apatite USNM 104021, microcline USNM 143966 (Jarosewich et al., 1980), olivine Ch-1, and spinel Yb-126 (Lavrentev et al., 1974) were used as standards for calibration.

\section{Ion Microprobe}

Primary melt inclusions in olivine and clinopyroxene phenocrysts were analyzed for trace elements and $\mathrm{H}_{2} \mathrm{O}$ with a Cameca IMS $3 \mathrm{f}$ ion microprobe at the CRPG-CNRS (Nancy, France). A set of 15 synthetic and natural basaltic, andesitic, and rhyolitic glasses was used as standards for calibration (Table 2).

Table 1. Selected samples.

\begin{tabular}{lrrl}
\hline \multirow{2}{*}{$\begin{array}{c}\text { Core, section, } \\
\text { interval (cm) }\end{array}$} & \multicolumn{2}{c}{ Depth (mbsf) } & \\
\cline { 2 - 3 } & \multicolumn{1}{c}{ Bottom } & \\
\hline 157-953C- & & & \multicolumn{1}{c}{ Rock type } \\
82R-1, 52-62 & 956.92 & 957.02 & Hyaloclastite tuff \\
82R-1,94-103 & 957.34 & 957.43 & Hyaloclastite tuff \\
83R-7, 0-12 & 973.64 & 973.76 & Hyaloclastite tuff \\
89R-1, 0-13 & 1017.20 & 1017.33 & Hyaloclastite tuff \\
90R-1, 82-101 & 1024.52 & 1024.71 & Hyaloclastite tuff with basalt fragmants \\
93R-5, 13-27 & 1058.29 & 1058.43 & Ol-Cpx basalt fragmant \\
93R-6, 45-55 & 1060.08 & 1060.18 & Ol-Cpx basalt fragment \\
97R-2, 0-16 & 1092.47 & 1092.59 & Hyaloclastite tuff \\
98R-1, 0-12 & 1100.90 & 1101.02 & Hyaloclastite tuff \\
102R-1, 8-28 & 1139.48 & 1139.68 & Hyaloclastite tuff with basalt fragmants \\
157-956B- & & & \\
44R-3, 57-71 & 574.27 & 574.41 & Hyaloclastite tuff with basalt fragments \\
45R-3, 120-132 & 584.09 & 584.21 & Hyaloclastite tuff \\
45R-CC, 7-17 & 585.15 & 585.25 & Hyaloclastite tuff \\
\hline
\end{tabular}

Note: $\mathrm{Ol}=$ olivine, and $\mathrm{Cpx}=$ clinopyroxene.

\section{Trace Elements}

The technique used for trace element analyses was similar to that described by Gurenko and Chaussidon (1995). Analytical conditions were $10 \mathrm{kV}$ accelerating voltage of $\mathrm{O}^{-}$ions, and $15-30 \mathrm{nA}$ of primary beam current. Positive secondary ions were analyzed at a mass resolution of $\approx 500$ with energy filtering of $-80 \pm 10 \mathrm{~V}$. Remaining oxide interferences were eliminated by deconvolution techniques by the measurement of 31 atomic masses in the range from 138 to 180 following Fahey et al. (1987). Secondary ion yields, defined for each element as a ratio of element total ionic intensity relative to ${ }^{30} \mathrm{Si}^{+}$over the element atomic concentration relative to $\mathrm{Si}$, were determined for $\mathrm{Ti}, \mathrm{V}, \mathrm{Sr}, \mathrm{Y}, \mathrm{Zr}, \mathrm{Nb}, \mathrm{Ba}, \mathrm{La}, \mathrm{Ce}, \mathrm{Nd}, \mathrm{Sm}, \mathrm{Eu}, \mathrm{Dy}, \mathrm{Er}$, and $\mathrm{Yb}$ on the basis of 12 standard glasses (20-1, 29-3, 30-2, 40-2, 519-4-1, 529-4, TRD-65, TRDS-56, TRDS-27, TRDS-15, 316, and 350; Table 2). Trace element concentrations in melt inclusions were calculated from the determined ion yields and $\mathrm{SiO}_{2}$ contents measured by electron microprobe. The precision is better than $\pm 10 \%$ relative for Ti, V, Sr, Y, $\mathrm{Zr}, \mathrm{Ba}, \mathrm{La}, \mathrm{Ce}, \mathrm{Nd}, \mathrm{Sm}, \mathrm{Eu}, \mathrm{Yb}$, and varies between \pm 10 and $\pm 17 \%$ relative for $\mathrm{Nb}, \mathrm{Dy}$, and $\mathrm{Er}$ (see $1 \sigma$ of ion yields in Table 2).

\section{$\mathrm{H}_{2} \mathrm{O}$ Concentrations}

$\mathrm{H}_{2} \mathrm{O}$ concentrations in melt inclusions were measured at $10 \mathrm{kV}$ of accelerating voltage and 15-30 nA of primary beam current with the beam size of $10 \mu \mathrm{m}$, using a technique described by Sobolev and Chaussidon (1996). Positive secondary ${ }^{1} \mathrm{H}^{+}$and ${ }^{30} \mathrm{Si}^{+}$ions were analyzed at a mass resolution of $\approx 1200$ with an energy filtering of -100 $\pm 10 \mathrm{~V}$. To minimize the $\mathrm{H}_{2} \mathrm{O}$ background, the ion probe was repeatedly baked at $120^{\circ} \mathrm{C}$ overnight. We then started measurements when the ${ }^{1} \mathrm{H}^{+} / 30 \mathrm{Si}^{+}$ratio measured on the host olivine was lower than the value corresponding to the $\mathrm{H}_{2} \mathrm{O}$ content of $0.03 \mathrm{wt} \%$ (Sobolev and Chaussidon, 1996), and carried the analyses out using a liquid nitrogen cold trap in the source (Deloule et al., 1991). A calibration curve between wt $\% \mathrm{H}_{2} \mathrm{O}$ relative to $\mathrm{wt} \% \mathrm{SiO}_{2}$ and measured ${ }^{1} \mathrm{H}^{+} /{ }^{30} \mathrm{Si}^{+}$ratios was established on the basis of nine glass standards (JV1, 40-2, 30-2, 20-1, 29-3, TRDS-27, TRDS-15, and two GRPG glass standards; Table 2) as a linear regression:

$$
\mathrm{H}_{2} \mathrm{O} / \mathrm{SiO}_{2}=0.04447 \times{ }^{1} \mathrm{H}^{+} / 30 \mathrm{Si}^{+}+0.00044, \mathrm{r}=0.99
$$

The slope of the calibration curve (coefficient at ${ }^{1} \mathrm{H}^{+} /{ }^{30} \mathrm{Si}^{+}$) determined during this work is very close to this previously reported by

Table 2. Intervals of concentrations in standard glasses used for calibration, and determined ion yields of elements analyzed.

\begin{tabular}{lccccc}
\hline \multirow{2}{*}{$\begin{array}{c}\text { Element } \\
\end{array}$} & \multirow{2}{*}{$\begin{array}{c}\text { Mass of isotopes } \\
\text { analyzed }\end{array}$} & Interval of & \multicolumn{2}{c}{ Ion yields normalized to Si } \\
\cline { 3 - 5 } & & concentrations & This study & Literature & Ref. \\
\hline $\mathrm{H}$ & 1 & $0.11-2.96$ & $0.0115 \pm 0.0009$ & 0.0169 & 1 \\
$\mathrm{Ti}$ & 47 & $1242-9984$ & $2.25 \pm 0.17$ & $1.64-2.56$ & 2,3 \\
$\mathrm{~V}$ & 51 & $213-299$ & $1.57 \pm 0.11$ & $1.70-1.71$ & 2,3 \\
$\mathrm{Sr}$ & 88 & $31.0-255.3$ & $2.09 \pm 0.07$ & $2.54-2.90$ & 2,3 \\
$\mathrm{Y}$ & 89 & $5.7-39.3$ & $2.78 \pm 0.26$ & $3.47-3.56$ & 2,3 \\
$\mathrm{Zr}$ & 90 & $7.6-111.6$ & $2.13 \pm 0.10$ & $2.23-2.49$ & 2,3 \\
$\mathrm{Nb}$ & 93 & $0.48-19.20$ & $1.15 \pm 0.12$ & $1.22-1.39$ & 2,3 \\
$\mathrm{Ba}$ & 138 & $1.3-179.4$ & $1.22 \pm 0.12$ & $1.67-2.04$ & 2,3 \\
$\mathrm{La}$ & 139 & $0.62-11.51$ & $1.76 \pm 0.14$ & $2.27-2.48$ & 2,3 \\
$\mathrm{Ce}$ & 140,142 & $1.09-25.12$ & $1.70 \pm 0.14$ & $2.21-2.35$ & 2,3 \\
$\mathrm{Nd}$ & $142,143,145,146$ & $0.46-14.34$ & $1.83 \pm 0.17$ & $2.59-2.82$ & 2,3 \\
$\mathrm{Sm}$ & $147,148,152,154$ & $0.28-4.22$ & $2.03 \pm 0.16$ & $2.59-2.78$ & 2,3 \\
$\mathrm{Eu}$ & 151,153 & $0.17-1.47$ & $2.41 \pm 0.12$ & $2.80-2.92$ & 2,3 \\
$\mathrm{Dy}$ & $161,162,163$ & $0.82-7.04$ & $1.91 \pm 0.21$ & $2.50-3.07$ & 2,3 \\
$\mathrm{Er}$ & $166,167,168$ & $0.59-4.93$ & $1.95 \pm 0.32$ & $2.45-3.09$ & 2,3 \\
$\mathrm{Yb}$ & $168,171,172,173,174$ & $0.83-4.48$ & $1.91 \pm 0.14$ & $2.47-2.95$ & 2,3 \\
& & & & & \\
\hline
\end{tabular}

Notes: Concentrations of $\mathrm{H}\left(\mathrm{wt} \% \mathrm{H}_{2} \mathrm{O}\right)$ and trace elements $(\mathrm{ppm})$ in standard glasses. Standards used for calibration are synthetic and fresh natural glasses, including JV1 obsidian glass from Macusani, southeast Peru (Pichavant et al., 1987), MORB glasses dredged from the Mid-Atlantic Ridge, from the Siqueriros Transform Fault (20-1), East Pacific Rise (29-3, 30-2, 40-2; A.V. Sobolev, pers. comm., 1993), FAMOUS area (519-4-1, 529-4; Langmuir et al., 1977) glasses from the Troodos Upper Pillow Lavas, Cyprus (TRD-65, TRDS-56, TRDS-27, and TRDS-15; Rautenschlein et al., 1985), and two CRPG standard glasses with 1.82 and $2.96 \mathrm{wt} \% \mathrm{H}_{2} \mathrm{O}$, and 70.65 and $70.42 \mathrm{wt} \% \mathrm{SiO} \mathrm{O}_{2}$, respectively (M. Chaussidon, pers. comm., 1994) Ion yields are given at $\pm 1 \sigma$. Ref. = references: $1=$ Sobolev and Chaussidon $(1996), 2=$ Hinton $(1990)$, and $3=$ Gurenko and Chaussidon $(1995)$. 
Sobolev and Chaussidon (1996) for $\mathrm{H}_{2} \mathrm{O}$ concentrations $<1 \mathrm{wt} \%$ and obtained at similar analytical conditions (i.e., 0.03327). Up to three spots were measured within melt inclusions characterized by the lowest $\mathrm{H}_{2} \mathrm{O}$ concentrations. The precision estimated on the basis of $\mathrm{H}$ ion yield (Table 2 ) is always better than $\pm 10 \%$ relative, and the detection limit is believed to be $\approx 0.03 \mathrm{wt} \% \mathrm{H}_{2} \mathrm{O}$, as measured on host olivine.

\section{Microthermometry of Fluid Inclusions}

Microthermometric study of fluid inclusions was performed at GEOMAR Research Center (Kiel, Germany) using a FLUIDINC gas-flow stage. The thermocouple was calibrated in the temperature interval $-56.6^{\circ}$ to $+573^{\circ} \mathrm{C}$ using SYNFLINC synthetic fluid inclusions in quartz and at $-196^{\circ} \mathrm{C}$ (temperature of liquid $\mathrm{N}_{2}$ ). Accuracy and precision of $\mathrm{CO}_{2}$ triple point measurements were estimated at better than $\pm 0.2^{\circ} \mathrm{C}$; homogenization temperatures are reproducible to better than $\pm 0.5^{\circ} \mathrm{C}$.

\section{MINERAL CHEMISTRY \\ Olivine}

Olivine phenocrysts range from $\mathrm{Fo}_{80}$ to $\mathrm{Fo}_{89}$ corresponding to the entire range of olivine compositions known for Miocene subaerial shield basalts of Gran Canaria (Gurenko et al., 1996) are similar to those analyzed from other samples drilled at Site 953 (Schmincke and Segschneider, Chap. 12, this volume). $\mathrm{CaO}$ contents (0.21-0.33 $\mathrm{wt} \%$ ) are lower than those in olivine phenocrysts from Miocene subaerial shield basalts on Gran Canaria (Fig. 3A, B; Table 3; Appendix Tables 1-3), but higher than in olivines from mantle xenoliths of the Cr-diopside series xenoliths on Hierro and the spinel-harzburgite suite xenoliths on Lanzarote (Canary Islands; Neumann, 1991; Neumann et al., 1995), as well as in olivines from mantle xenoliths in general (<0.15 wt\% CaO; Hervig et al., 1986; Fig. 3B). Sample 157953C-93R-5, 13-27 cm, contains phenocrysts of high magnesian olivine ( $>86 \mathrm{~mol} \% \mathrm{Fo}$ ), which are thought to have crystallized from
$157-953 C-93 R-5,13-27 \mathrm{~cm}$

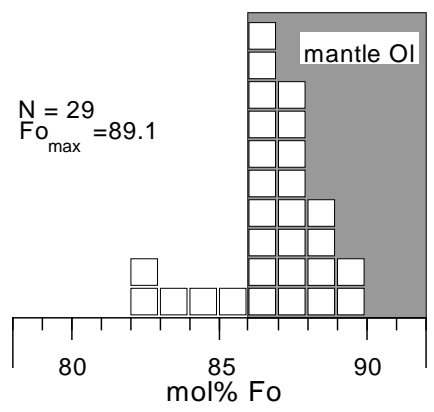

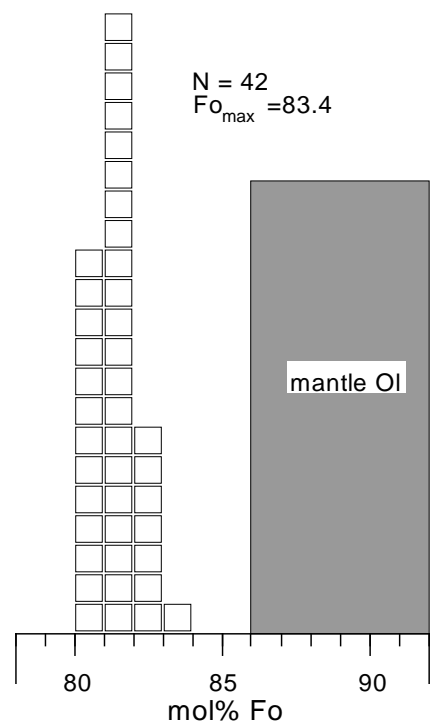

Figure 3. Olivine composition. A. Histograms demonstrating the Fo contents in olivine phenocrysts from basalt fragments (Samples 157-953C-93R-5, 13-27 cm, and 93R-6, 45-55 cm). $\mathrm{N}=$ number of analyzed olivine crystals, and $\mathrm{Fo}_{\max }=$ composition of the most magnesian olivine found. B. $\mathrm{CaO}$ contents vs. Fo in olivine phenocrysts and clinopyroxene-hosted inclusions of olivine. All olivine phenocrysts are $\mathrm{CaO}$-rich compared to olivine from mantle xenoliths (e.g., Hervig et al., 1986) implying that the most magnesian olivines $\mathrm{Fo}_{>86}$ from Sample 157-953C-93R-5, 13-27 cm, are phenocrysts of mantle-derived magmas rather than xenocrysts produced by disintegration of mantle peridotite. Compositions of olivine phenocrysts from Miocene shield basalts on Gran Canaria are taken from Gurenko et al. (1996) and Gurenko (unpubl. data), compositions of olivine from Site 953 are from Schmincke and Segscheider (Chap. 12, this volume), and olivine from Hierro and Lanzarote xenoliths are after Neumann (1991) and Neumann et al. (1995).

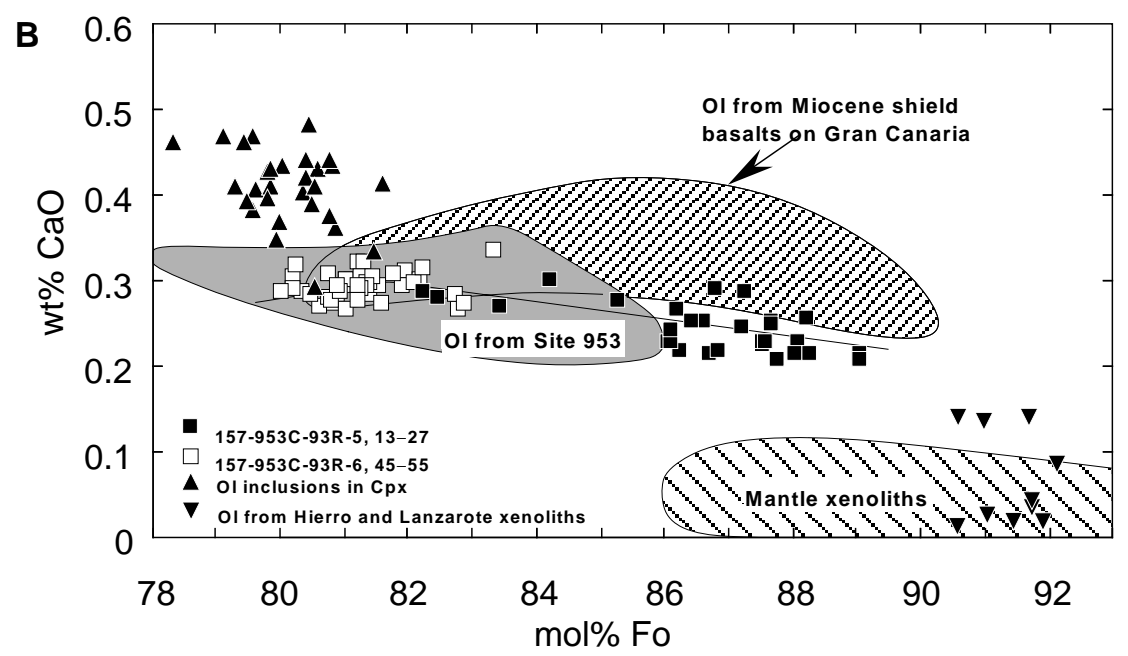


Table 3. Summary of mineral chemistry.

\begin{tabular}{|c|c|c|c|c|c|c|c|c|c|c|c|c|}
\hline \multirow{2}{*}{$\begin{array}{l}\text { Core, section, } \\
\text { interval }(\mathrm{cm})\end{array}$} & \multicolumn{2}{|c|}{ Olivine } & \multicolumn{4}{|c|}{ Spinel } & \multicolumn{4}{|c|}{ Clinopyroxene } & \multicolumn{2}{|c|}{ Plagioclase } \\
\hline & No. & Fo & No. & $\mathrm{Mg}_{\mathrm{sp}}$ & $\mathrm{Cr} \#$ & No. & $\mathrm{Mg}_{\mathrm{cpx}}$ & Wo & En & Fs & No. & An \\
\hline \multicolumn{13}{|l|}{ 157-953C- } \\
\hline $82 \mathrm{R}-1,52-62$ & $1^{*}$ & 79.5 & $1^{*}$ & 0.268 & 0.254 & 20 & $0.774-0.879$ & $44.4-46.7$ & $41.4-47.9$ & $6.6-12.1$ & 0 & - \\
\hline 82R-1, 94-103 & $1^{*}$ & 78.3 & 0 & - & - & 4 & $0.797-0.842$ & $45.3-46.0$ & 43.1-45.6 & $8.6-11.0$ & 0 & - \\
\hline $83 \mathrm{R}-7,0-12$ & $5^{*}$ & $79.1-81.2$ & $1^{*}$ & 0.436 & 0.666 & 7 & $0.805-0.842$ & $40.8-43.7$ & $45.4-49.8$ & $9.3-11.1$ & 0 & - \\
\hline $89 \mathrm{R}-1,0-13$ & $5 *$ & $79.9-80.8$ & $4 *$ & $0.320-0.402$ & $0.541-0.615$ & 13 & $0.787-0.882$ & $41.3-45.8$ & $42.8-50.9$ & $6.8-11.7$ & 0 & - \\
\hline 90R-1, 82-101 & $7^{*}$ & $79.6-81.6$ & $2^{*}$ & $0.393-0.394$ & $0.605-0.613$ & 10 & $0.805-0.831$ & $41.3-43.8$ & $45.6-48.8$ & $9.5-11.2$ & 0 & - \\
\hline $93 \mathrm{R}-5,13-27$ & $1 * *$ & 79.3 & $24 * *$ & $0.350-0.575$ & $0.651-0.731$ & 17 & $0.792-0.841$ & $37.4-42.6$ & $46.1-50.6$ & $9.4-12.1$ & 0 & - \\
\hline $93 R-6.45-55$ & $\begin{array}{l}29 \\
42\end{array}$ & $\begin{array}{l}82.3-89.1 \\
80.1-83.4\end{array}$ & ${ }_{2}^{0} *$ & $0.400-0.406$ & $0.630-0.632$ & $\begin{array}{l}0 \\
21\end{array}$ & $0.750-0.851$ & $39 \overline{1-447}$ & $439-502$ & $8.4-14.7$ & $\begin{array}{l}0 \\
0\end{array}$ & 二 \\
\hline & 0 & - & $14 * *$ & $0.399-0.443$ & $0.634-0.705$ & $2^{* * *}$ & $0.794-0.818$ & $41.4-44.7$ & $43.9-48.1$ & $10.7-11.4$ & 0 & - \\
\hline $97 \mathrm{R}-2,0-16$ & $4^{*}$ & $80.4-81.5$ & $3^{*}$ & $0.263-0.411$ & $0.520-0.609$ & 19 & $0.776-0.849$ & $38.3-44.2$ & $45.1-50.9$ & $8.7-13.2$ & 0 & - \\
\hline $98 \mathrm{R}-1,0-12$ & $1^{*}$ & 80.5 & $3^{*}$ & $0.398-0.409$ & $0.576-0.681$ & 25 & $0.768-0.833$ & $37.9-44.5$ & 43.3-51.7 & $9.6-13.1$ & 0 & - \\
\hline $102 \mathrm{R}-1,8-28$ & $4^{*}$ & 79.6-80.9 & $7 *$ & $0.305-0.426$ & $0.560-0.663$ & 36 & $0.770-0.839$ & $38.4-46.0$ & $41.8-51.3$ & $9.5-12.8$ & 0 & - \\
\hline \multicolumn{13}{|l|}{ 157-956B- } \\
\hline 44R-3, 57-71 & 0 & - & $2^{*}$ & $0.211-0.232$ & $0.172-0.179$ & 15 & $0.744-0.867$ & $41.5-44.9$ & $43.3-48.1$ & $7.4-15.0$ & 0 & - \\
\hline $45 \mathrm{R}-3,120-132$ & 0 & - & $7 *$ & $0.256-0.372$ & $0.281-0.601$ & 17 & $0.793-0.895$ & $43.0-45.7$ & $43.7-49.5$ & $5.8-11.5$ & $1 *$ & 68.4 \\
\hline 45R-CC, $7-17$ & 0 & - & $4 *$ & $0.219-0.431$ & $0.194-0.744$ & 11 & $0.750-0.858$ & $43.2-46.2$ & $41.2-47.9$ & $7.9-13.8$ & $2 *$ & $75.7-82.7$ \\
\hline
\end{tabular}

Notes: Individual analyses are given in Appendix Tables 1 through 3. No. $=$ number of microprobe analyses, $\mathrm{Fo}=\mathrm{mol} \%$ forsterite, $\mathrm{Mg} \#_{\mathrm{sp}}=\mathrm{Mg} /\left(\mathrm{Mg}+\mathrm{Fe}{ }_{2}^{+}\right)$atomic ratio, $\mathrm{Cr} \#=\mathrm{Cr} /$ $(\mathrm{Cr}+\mathrm{Al})$ atomic ratio, $\mathrm{Mg} \#_{\mathrm{cpx}}=\mathrm{Mg} /\left(\mathrm{Mg}+\mathrm{Fe}_{\mathrm{tot}}\right)$ atomic ratio, where $\mathrm{Fe}_{\mathrm{tot}}$ is an $\mathrm{Fe}$ concentration measured with electron microprobe, Wo $=$ wollastonite $\left[\mathrm{Ca} /\left(\mathrm{Ca}+\mathrm{Mg}+\mathrm{Fe} \mathrm{tot}_{\mathrm{tot}}\right)\right.$ atomic ratio $], \mathrm{En}=$ enstatite $\left[\mathrm{Mg} /\left(\mathrm{Ca}+\mathrm{Mg}+\mathrm{Fe}_{\mathrm{tot}}\right)\right.$ atomic ratio $] ; \mathrm{Fs}=$ ferrosilite $\left[\mathrm{Fe}_{\mathrm{tol}} /\left(\mathrm{Ca}+\mathrm{Mg}+\mathrm{Fe}_{\mathrm{tot}}\right)\right.$ atomic ratio $] ;$ An $=$ mol\% anorthite. $*=$ inclusion in clinopyroxene, $* *=$ inclusion in olivine, and $-=$ phase is not present.

mantle-derived magmas rather than being derived from the disintegration of mantle peridotites. Concentrations of $\mathrm{Ni}$ and $\mathrm{Cr}$ ranging from 0.25 to $0.51 \mathrm{wt} \% \mathrm{NiO}$ and from 0.02 to $0.12 \mathrm{wt} \% \mathrm{Cr}_{2} \mathrm{O}_{3}$ also indicate that olivine phenocrysts crystallized from mantle-derived magmas.

\section{Clinopyroxene}

Clinopyroxene phenocrysts are optically and chemically heterogeneous and show a broad range of compositions: $\mathrm{Mg}_{\mathrm{cpx}}[\mathrm{Mg} /$ $\left.\left(\mathrm{Mg}+\mathrm{Fe}_{\mathrm{tot}}\right)\right]=0.75-0.88$ and $\mathrm{Wo}_{37-47}, \mathrm{En}_{44-52}, \mathrm{Fs}_{7-15}$ found in the samples from Site 953, and $\mathrm{Mg} \#_{\text {cpx }}=0.74-0.90$ and $\mathrm{Wo}_{42-46}, \mathrm{En}_{41-50}$, $\mathrm{Fs}_{6-15}$ from Site 956 (Fig. 4A; Table 3; Appendix Tables 1-3). Within the each sample, the compositional variations are more restricted (Table 3). The widest range is shown by Samples 157-953C-82R-1, $52-62 \mathrm{~cm}\left(\mathrm{Mg} \#_{\mathrm{cpx}}=0.77-0.88\right), 89 \mathrm{R}-1,0-13 \mathrm{~cm}\left(\mathrm{Mg} \#_{\mathrm{cpx}}=0.79-\right.$ $0.88)$, and $157-956 \mathrm{~B}-45 \mathrm{R}-3,120-132 \mathrm{~cm}\left(\mathrm{Mg} \#_{\mathrm{cpx}}=0.79-0.90\right)$. Sample 157-953C-93R-5, 13-27 cm, which is characterized by the widest range of olivine compositions $\left(\mathrm{Fo}_{82-89}\right)$, contains clinopyroxene of a relatively narrow compositional range $\left(\mathrm{Mg} \#_{\text {cpx }}=0.79-\right.$ 0.84). Ti and $\mathrm{Al}$ concentrations correlate negatively with $\mathrm{Mg \#}_{\mathrm{cpx}}$ and range from 0.88 to $2.74 \mathrm{wt} \% \mathrm{TiO}_{2}$ and from 1.67 to $5.72 \mathrm{wt} \% \mathrm{Al}_{2} \mathrm{O}_{3}$ in clinopyroxene phenocrysts from Site 953 , and from 0.65 to 2.58 wt $\% \mathrm{TiO}_{2}$ and 1.55 to $5.28 \mathrm{wt} \% \mathrm{Al}_{2} \mathrm{O}_{3}$ from Site 956 (Fig. 4B; Appendix Tables 1-3).

Clinopyroxene phenocrysts are strongly zoned, as shown by variations of $\mathrm{Ti}, \mathrm{Al}$, and $\mathrm{Mg} \#_{\mathrm{cpx}}$ within single crystals and are characterized by concentric zoning, either normal or inverse. Three zoned clinopyroxenes overlap nearly the whole compositional range with respect to $\mathrm{Mg \#} \#_{\text {cpx }}$ values, $\mathrm{TiO}_{2}$, and $\mathrm{Al}_{2} \mathrm{O}_{3}$ contents that were determined on the basis of 200 clinopyroxene analyses (see insets in Fig. 4B, C).

\section{INCLUSIONS IN OLIVINE AND CLINOPYROXENE}

Olivine and clinopyroxene phenocrysts contain: (1) inclusions of crystals (inclusions of olivine and plagioclase in clinopyroxene, inclusions of clinopyroxene in olivine, and inclusions of Fe-Ti oxides in both olivine and clinopyroxene); (2) melt inclusions (multiphase inclusions of partially crystallized melt, and quenched glass inclusions); and (3) gas-liquid fluid inclusions. Following the classification of Roedder (1984), we subdivide melt, crystal, and fluid inclu- sions into primary, pseudosecondary, and secondary types. Primary inclusions occur as single, isolated inclusions, or as randomly oriented groups, and commonly mark zones of host crystal growth. Pseudosecondary inclusions occur along short, healed fractures that do not extend to the grain surfaces. Secondary inclusions are usually controlled by sealed cracks. We studied only primary inclusions because they contain direct information on the conditions of magma evolution. Pseudosecondary and secondary inclusions were excluded from further considerations. All types of inclusions commonly occur in combination with one another, indicating heterogeneous "crystalsilicate melt-fluid" entrapment. One spherical sulfide inclusion of $\sim 10 \mu \mathrm{m}$ in size was found in clinopyroxene of $\mathrm{Mg} \#=0.79$ in Sample 157-956B-44R-3, 57-71 cm.

\section{Inclusions of Crystals}

Dark brown and black inclusions of Fe-Ti oxides (from a few to $20-30 \mu \mathrm{m}$ in size) in olivine and clinopyroxene phenocrysts is the main type of crystalline inclusions. Clinopyroxene inclusions in olivine, and olivine and plagioclase inclusions in clinopyroxene (usually 5-20 $\mu \mathrm{m}$ in size) are minor.

Compositions of olivine, clinopyroxene, and plagioclase inclusions are listed in Table 3 and Appendix Table 2. Inclusions of olivine in clinopyroxene phenocrysts occur in all samples studied. Olivine inclusions analyzed in samples from Site 953 have a compositions range from 78 to $82 \mathrm{~mol} \%$ Fo and are similar to olivine phenocrysts from Sample 157-953C-93R-6, 45-55 cm (Fig. 3B). Concentrations of $\mathrm{Ca}$ in olivine inclusions are slightly higher $(0.30-$ $0.48 \mathrm{wt} \% \mathrm{CaO}$ ) compared to those of phenocrysts that may be due to the redistribution of $\mathrm{Ca}$ between included olivine and host clinopyroxene at temperatures and pressures lower than those of inclusion entrapment. Alternatively, these elevated $\mathrm{CaO}$ contents may also be due to the effects of secondary X-ray fluorescence of $\mathrm{Ca}$ from the adjoining Ca-rich host clinopyroxene because of the small size of olivine inclusions, as suggested by Dalton and Lane (1996).

Two inclusions of clinopyroxene in olivine phenocrysts of $\mathrm{Fo}_{80.8}$ and of $\mathrm{Fo}_{81.2}$ from Sample 157-953C-93R-6, 45-55 cm, are characterized by $\mathrm{Mg} \#_{\mathrm{cpx}}=0.79-0.82, \mathrm{Wo}_{41-45}, \mathrm{En}_{44-48}, \mathrm{Fs}_{11}, 1.39-1.80 \mathrm{wt} \%$ $\mathrm{TiO}_{2}$, and 3.35-3.70 wt $\% \mathrm{Al}_{2} \mathrm{O}_{3}$, and fall within the broad compositional range defined for clinopyroxene phenocrysts (Table 3; Appendix Table 2).

Plagioclase inclusions $\left(\mathrm{An}_{68-83}\right)$ were found in clinopyroxene phenocrysts only in Samples 157-956B-45R-3, 120-132 cm, and 45-CC, 
Figure 4. Composition of clinopyroxene phenocrysts from hyaloclastites and basalt fragments. A. Wo-En-Fs triangular diagrams. $\mathrm{N}=$ number of analyzed clinopyroxene crystals B. $\mathrm{TiO}_{2}$ vs. $\mathrm{Mg} /(\mathrm{Mg}+\mathrm{Fe})$. C. $\mathrm{Al}_{2} \mathrm{O}_{3}$ vs. $\mathrm{Mg} /$ $(\mathrm{Mg}+\mathrm{Fe})$. The insets in $\mathrm{B}$ and $\mathrm{C}$ represent the zonation of three clinopyroxene phenocryts and are plotted in the same coordinates. $\mathrm{Mg} /(\mathrm{Mg}+\mathrm{Fe})$ is given as atomic ratio.
A

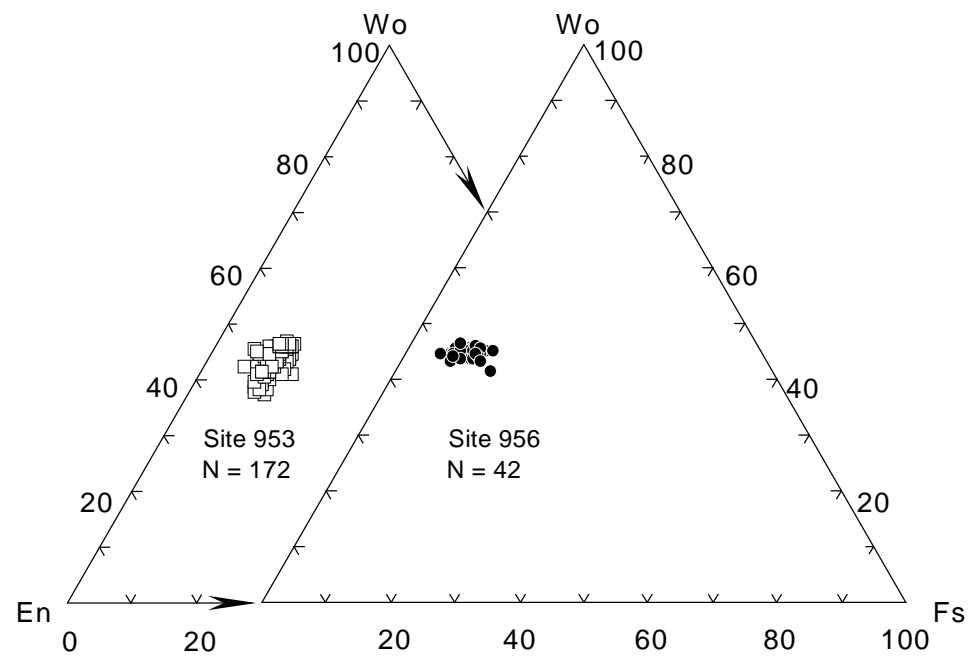

B

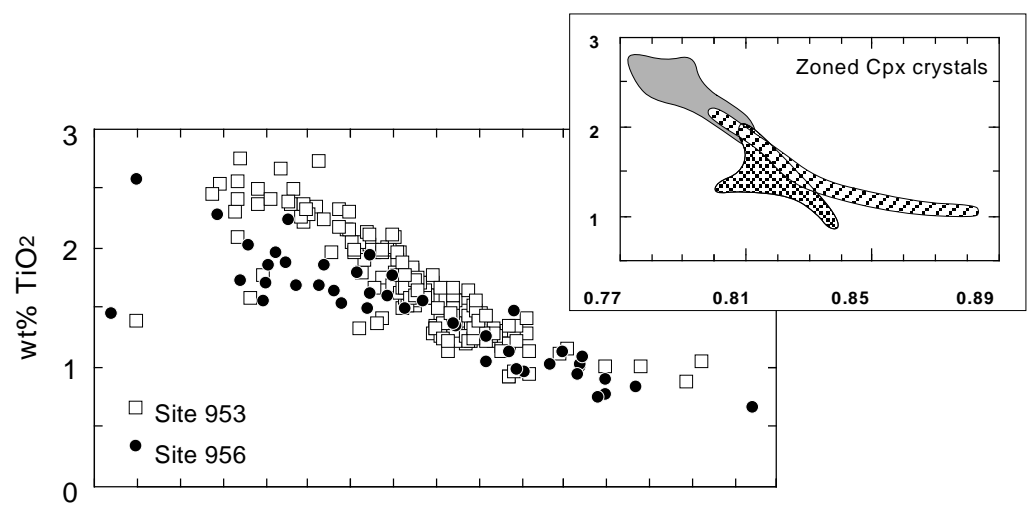

C

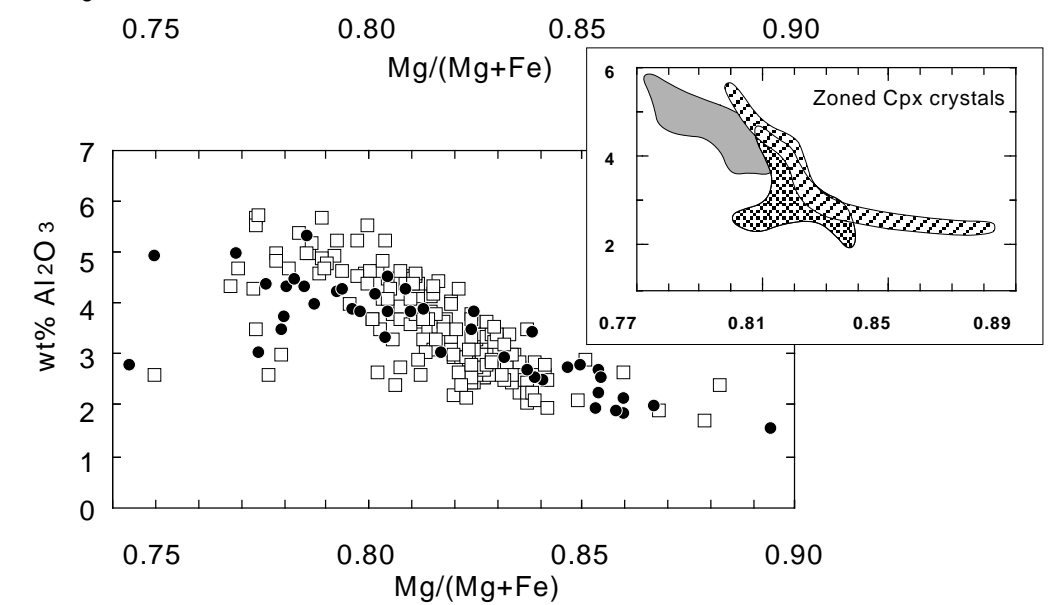

7-17 cm (Table 3; Appendix Table 2). Presence of plagioclase inclusions in low-magnesium clinopyroxene (both in clinopyroxene of $\mathrm{Mg} \#_{\mathrm{cpx}}=0.79$ ) and only trace amounts of plagioclase phenocrysts observed in these samples suggests that olivine-clinopyroxene-plagioclase cotectic crystallization only began during the late stage of magma crystallization.

Inclusions of spinel-group minerals (here called "spinel") and titanomagnetite were found throughout the whole compositional range of olivine and clinopyroxene phenocrysts. They represent a solid solution of $(\mathrm{Mg}, \mathrm{Fe}) \mathrm{Al}_{2} \mathrm{O}_{4}-(\mathrm{Mg}, \mathrm{Fe}) \mathrm{Cr}_{2} \mathrm{O}_{4}-(\mathrm{Mg}, \mathrm{Fe}) \mathrm{Fe}_{2} \mathrm{O}_{4}-\mathrm{Fe}_{2} \mathrm{TiO}_{4}$, and are characterized by a wide range of $\mathrm{TiO}_{2}(2.48-18.69 \mathrm{wt} \%), \mathrm{Mg \#}$ sp $\left[\mathrm{Mg} /\left(\mathrm{Mg}+\mathrm{Fe}^{2+}\right)\right]=0.21-0.58$, and $\mathrm{Cr} \#[\mathrm{Cr} /(\mathrm{Cr}+\mathrm{Al})]=0.17-0.74$ (Fig. 5; Table 3; Appendix Table 1). With respect to $\mathrm{Mg \#}$ and $\mathrm{Cr} \#$, the spinel inclusions are very close to the spinels included in olivine from the subaerial Miocene shield basalts on Gran Canaria (Gurenko et al., 1996), to the spinel inclusions in olivine from Mauna Loa subaerial shield tholeiitic picrite and oceanite, as well as to the spinel phenocrysts from Kilauea's Puna Ridge and Mauna Loa submarine lavas, Hawaii (Sobolev and Nikogosian, 1994; Clague et al., 1995; Garcia et al., 1995), but extend to low $\mathrm{Cr} \#$ and more Ti-rich compositions (Fig. 5A, B).

The Cr\# of spinel inclusions in olivine and clinopyroxene correlate positively with the composition of their host minerals (Fig. 6A, C). Spinels trapped in clinopyroxene phenocrysts show two different evolutionary trends defined for Sites 953 and 956 (Fig. 6C). The Cr\# of spinels from Site 953 ranges between 0.52 and 0.68 (except for one 
A

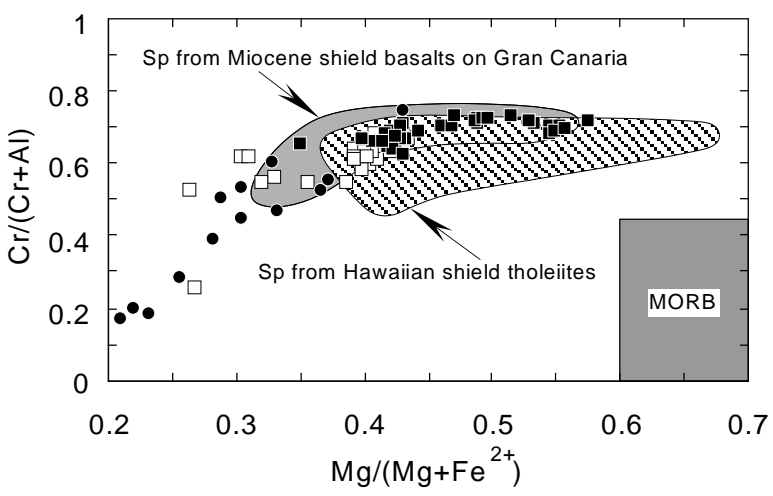

B

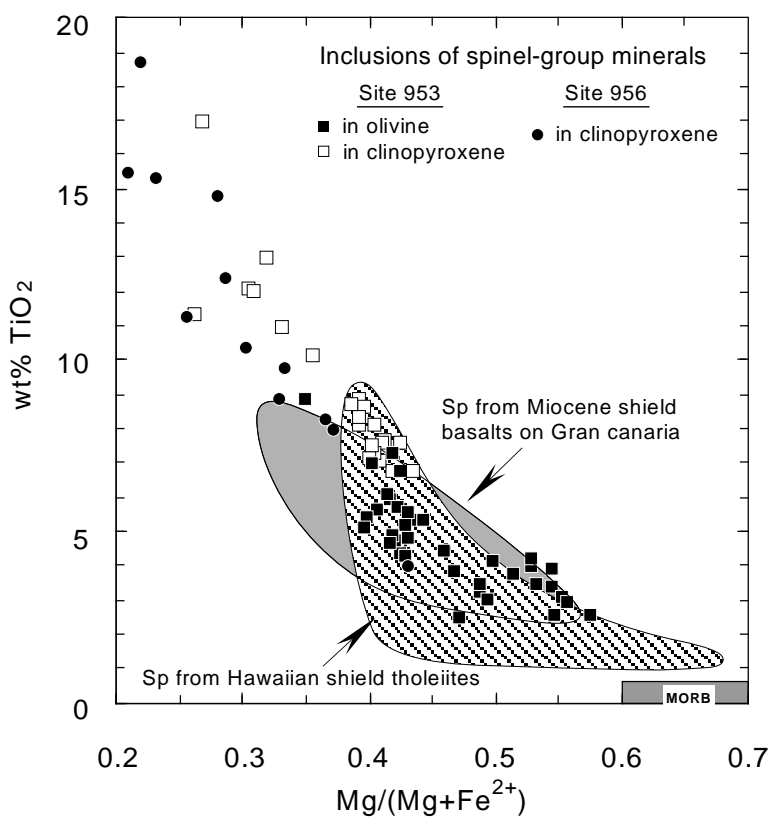

Figure 5. Spinel inclusions in olivine and clinopyroxene phenocrysts from hyaloclastites and basalt fragments. $\mathbf{A}$. $\mathrm{Cr} /(\mathrm{Cr}+\mathrm{Al})$ vs. $\mathrm{Mg} /\left(\mathrm{Mg}+\mathrm{Fe}^{2+}\right)$. B. $\mathrm{TiO}_{2}$ vs. $\mathrm{Mg} /\left(\mathrm{Mg}+\mathrm{Fe}^{2+}\right)$. In this figure and Figure $6, \mathrm{Cr} /(\mathrm{Cr}+\mathrm{Al})$ and $\mathrm{Mg} /$ $\left(\mathrm{Mg}+\mathrm{Fe}^{2+}\right)$ are given as atomic ratio. Spinel inclusions from submarine hyaloclastites are more $\mathrm{TiO}_{2}$-rich compared to spinel inclusions in olivine from Miocene shield basalts of Gran Canaria (Gurenko et al., 1996, and unpubl. data) and spinel phenocrysts and inclusions in olivine from Hawaiian submarine and subaerial shield tholeiites (taken from Sobolev and Nikogosian, 1994; Clague et al., 1995; Garcia et al., 1995). Box of MORB spinels is after Dick and Bullen (1984).

spinel inclusion with $\mathrm{Cr} \#=0.25$ ), whereas the $\mathrm{Cr} \#$ of spinels from the Site 956 is more variable (from 0.21 to 0.74 ).

$\mathrm{Fe}^{2+} / \mathrm{Fe}^{3+}$ ratios of olivine- and clinopyroxene-hosted spinel inclusions calculated on the basis of spinel stoichiometry range from 0.9 to 2.7 and positively correlate with the composition of host minerals (Fig. 6B, D). Olivine-hosted spinel inclusions have slightly higher $\mathrm{Fe}^{2+} / \mathrm{Fe}^{3+}$ ratios than those from Miocene shield basalts (Gurenko et al., 1996). Because the $\mathrm{Fe}^{2+} / \mathrm{Fe}^{3+}$ ratio of spinels is very sensitive to the $\mathrm{Fe}^{2+} / \mathrm{Fe}^{3+}$ ratio of the melt, compositions of spinel inclusions can be used to constrain the redox conditions of magma crystallization (see below). Low magnesium clinopyroxene phenocrysts $\left(\mathrm{Mg} \#_{\mathrm{cpx}}=\right.$ 0.77-0.80) also contain inclusions of long hair-like needle crystals which correspond in composition to ilmenite (Appendix Table 1).

\section{Fluid Inclusions}

We studied primary fluid inclusions in olivine phenocrysts from basalt fragments (Samples 157-953C-93R-5, 13-27 cm, and 93R-6, $45-55 \mathrm{~cm})$. Inclusions are spherical $(5-40 \mu \mathrm{m}$ in diameter) and consist of liquid and gas phases at room temperature. All inclusions were frozen to crystal aggregates in the temperature range between $-70^{\circ}$ and $-90^{\circ} \mathrm{C}$ and were then cooled further to $-190^{\circ} \mathrm{C}$ to check for the possible presence of $\mathrm{N}_{2}$ or $\mathrm{CH}_{4}$. Upon heating, no phase changes were observed between these temperatures and the $\mathrm{CO}_{2}$ triple point temperature at $-56.6 \pm 0.2^{\circ} \mathrm{C}(\mathrm{n}=12)$. This implies that the inclusions contain essentially pure $\mathrm{CO}_{2}$ and other components such as $\mathrm{CO}, \mathrm{N}_{2}$, $\mathrm{CH}_{4}, \mathrm{H}_{2} \mathrm{~S}$, and $\mathrm{SO}_{2}$ can only be present in trace quantities, if at all. Inclusions homogenize in the vapor in the temperature range from $+27.7^{\circ}$ to $+29.7^{\circ} \mathrm{C}(\mathrm{n}=14)$ and in the liquid from $+29.6^{\circ}$ to $+30.4^{\circ} \mathrm{C}$ $(\mathrm{n}=14)$, yielding carbon dioxide densities of $0.283-0.611 \mathrm{~g} / \mathrm{cm}^{3}$ (Angus et al., 1976).

\section{Melt Inclusions}

Primary melt inclusions are represented by glass (quenched glass \pm gas bubble/s) and multiphase (glass + daughter crystals \pm gas bubble/s) types ranging in size from 5 to $250 \mu \mathrm{m}$. Many of the inclusions in olivine and clinopyroxene are altered to clay minerals likely to have resulted from seawater infiltrating through cracks within the host minerals. Fresh inclusions are unlikely to have been affected by either syn-eruptive degassing or post-emplacement compositional modification, and, therefore, can be considered as representing the composition of melt during phenocryst crystallization.

Glass inclusions represent melt quenched to glass during eruption below sea level. This type of inclusion is abundant in clinopyroxene phenocrysts, but only a few small inclusions $(<15 \mu \mathrm{m})$ were found in olivine. Inclusions are subspherical to ellipsoidal and commonly have "negative crystal" shapes. Although they were subjected to effective quenching by seawater, crystallization of the host mineral occurred on the inclusion walls.

Multiphase inclusions are composed of glass and daughter crystals that are present, ranging from a few small discrete crystals up to 90-95 vol\% of crystalline phase, and of one or a few shrinkage bubbles. Most daughter crystals are clinopyroxene, and, more rare, are clinopyroxene and titanomagnetite. We do not exclude the possibility that olivine might have crystallized in clinopyroxene-hosted melt inclusions but, because of very small size of the crystals, it was difficult to define properly.

Within single crystals, one group of presumably syngenetic inclusions may be represented by all these diversities, from glassy through slightly crystallized ( $<5-10 \mathrm{vol} \%$ of daughter crystals) to strongly crystallized inclusions without correlation between size of inclusions and degree of melt crystallization. Most inclusions in olivine, whose fresh phenocrysts were found only in two samples of basalt fragments, are represented by multiphase types with up to $10 \mathrm{vol} \%$ of daughter crystals in Sample 157-953C-93R-6, 45-55 cm, and by strongly crystallized inclusions in $157-953 \mathrm{C}-93 \mathrm{R}-5,13-27 \mathrm{~cm}$.

We analyzed major elements in 86 glass and multiphase melt inclusions trapped by olivine and clinopyroxene phenocrysts in hyaloclastite tuffs and basalt fragments from Site 953, and 25 inclusions from Site 956 (Appendix Table 3). We restricted our measurements to inclusions that are dominated by glass $(>90 \%)$ compared to daughter crystals and do not contain spinel or titanomagnetite daughter crystals. The largest $(60-250 \mu \mathrm{m})$ and most representative inclusions $(n=22)$ were analyzed for trace elements and nine inclusions for $\mathrm{H}_{2} \mathrm{O}$ concentrations (Table 4). Because crystallization of the host mineral on the inclusion walls (olivine and clinopyroxene), together with daughter crystals (clinopyroxene), variably affects the inclusion compositions, all inclusions should be corrected for the effects of this post-entrapment crystallization. 


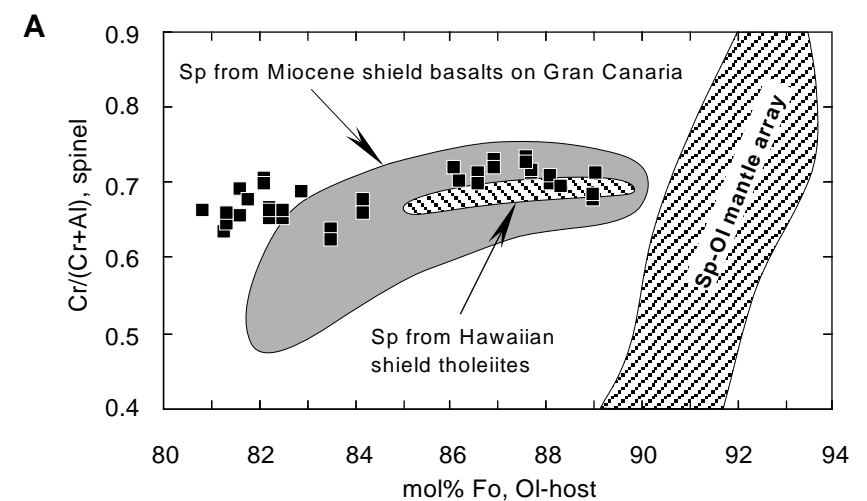

B

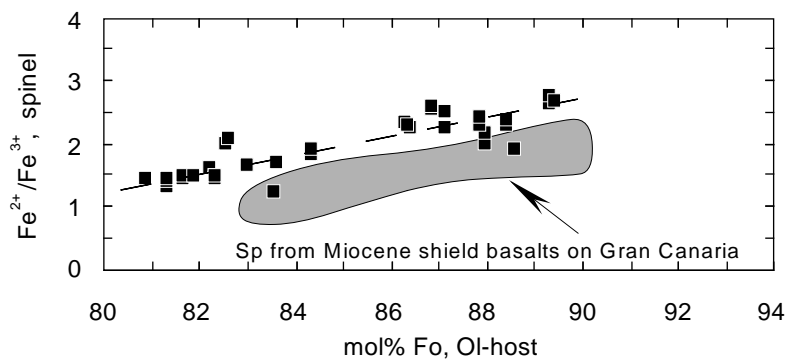

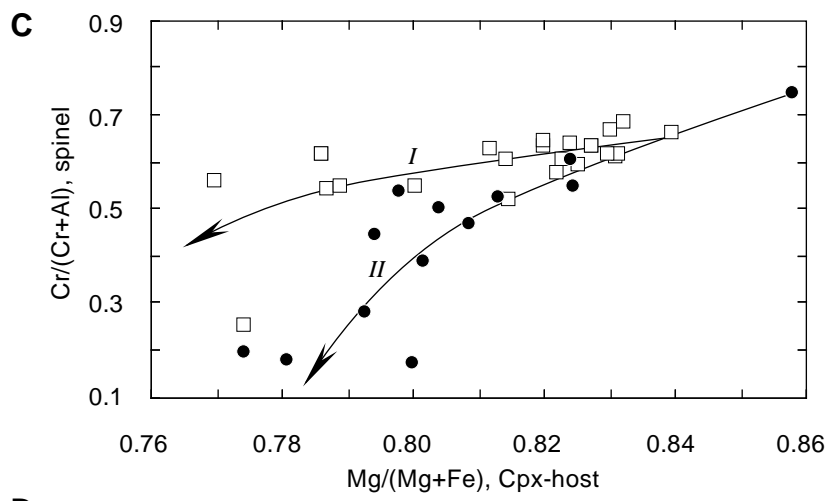

D

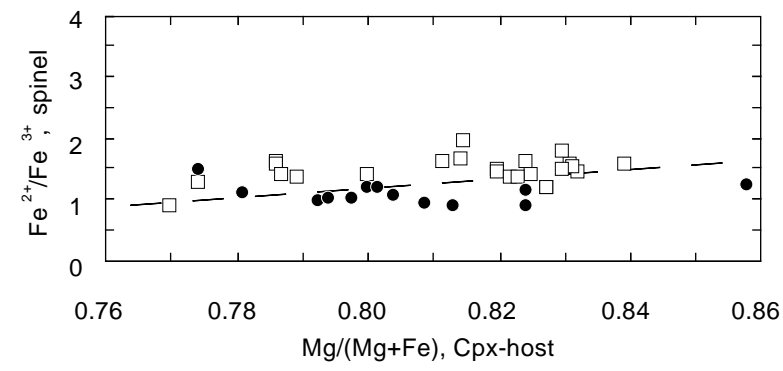

Figure 6. Inclusions of spinel-group minerals ( $\mathrm{Sp}$ ) and their host olivines $(\mathrm{Ol})$ and clinopyroxenes $(\mathrm{Cpx})$. $\mathbf{A}$. and $\mathbf{C}$. $\mathrm{Cr} /(\mathrm{Cr}+\mathrm{Al})$ of $\mathrm{Sp}$ vs. Fo contents of host $\mathrm{Ol}$ and $\mathrm{Mg} /(\mathrm{Mg}+\mathrm{Fe})$ of the host $\mathrm{Cpx}$. Compositions of the most magnesian spinels and their host olivines are close to spinel-olivine pairs from mantle peridotites (Sp-Ol mantle array; Arai, 1987) and to spinel inclusions from Hawaiian shield tholeiites after Sobolev and Nikogosian (1994). Compositional field of spinel inclusions in olivine from Miocene shield basalts on Gran Canaria is after Gurenko et al. (1996; unpubl. data). Spinels trapped by clinopyroxene phenocrysts show two different evolution trends defined for Sites 953 and 956. B. and D. Positive correlations of $\mathrm{Fe}^{2+} / \mathrm{Fe}^{3+}$ ratio (on an atomic basis) in Sp inclusions vs. composition of their host $\mathrm{Ol}$ and Cpx. For legend see Figure 5.

\section{COMPOSITION OF MELT INCLUSIONS}

\section{Correction for the Effects of Post-Entrapment Crystallization}

Post-entrapment crystallization affects the inclusion compositions that can be inferred, for instance, from the calculation of Fe-Mg distribution coefficients $\left(\mathrm{K}_{\mathrm{D}}\right)$ between trapped melt (i.e., glass inclusion compositions) and compositions of the host olivine. These $\mathrm{K}_{\mathrm{D}}$ values range from 0.10 to 0.16 and are systematically lower than the expected equilibrium value of $0.30 \pm 0.03$ (e.g., Roeder and Emslie, 1970), indicating that at the moment of quenching, the entrapped melt was equilibrated with olivine less magnesian than the host olivine. The same conclusion holds with respect to clinopyroxene-hosted inclusions by calculating the composition of clinopyroxene, which should be in equilibrium with the melt at the moment of trapping using the models of clinopyroxene-melt equilibria (e.g., Nielsen and Drake, 1979; Ariskin et al., 1987).

The correction was carried using the program PETROLOG (L.V. Danyushevsky and A.V. Sobolev, pers. comm., 1991). Olivine- and clinopyroxene-hosted inclusions without visible daughter crystals, and inclusions in clinopyroxene with clinopyroxene daughter crystals were corrected, modeling the melting of olivine for olivine-hosted inclusions, and of clinopyroxene for clinopyroxene-hosted inclusions. The calculation procedure represents cycles of two consequent subroutines. The first step includes calculation of the composition of olivine (or clinopyroxene) that should be in equilibrium with the melt (i.e., with a glass at the beginning and a currently changing melt composition in the consequent cycles) and the temperature of this equilibrium. The second step is a balance-mass addition of $0.1 \mathrm{wt} \%$ increments of calculated equilibrium olivine (or clinopyroxene). This incremental addition causes the continuous increase of the $\mathrm{Mg}$ / $(\mathrm{Mg}+\mathrm{Fe})$ value of the melt, and, consequently, increase of $\mathrm{Mg}$ / $(\mathrm{Mg}+\mathrm{Fe})$ of the olivine/clinopyroxene calculated to be in equilibrium with the newly obtained melt composition. As soon as the composition of the calculated equilibrium olivine (or clinopyroxene) became identical to the composition of the host mineral, the calculation routine was stopped. By this manner, we obtained: (1) the composition of melt equilibrated with the host mineral, which could be ascribed to the composition of the trapped melt, and (2) the temperature of the olivine/clinopyroxene-melt equilibria, which is thought to correspond to the temperature of melt inclusion trapping.

Inclusions in olivine containing clinopyroxene daughter crystals require correction for both olivine and clinopyroxene crystallization. In fact, our task was to model the melting of olivine and clinopyroxene along the cotectic line, whose compositions and melting proportions should be constrained only on the basis of melt (i.e., glass) composition and the existing experimental models of olivine-melt and clinopyroxene-melt equilibria. A simple and effective solution for a similar problem in an attempt to simulate magma crystallization trends was suggested by Nathan and Van Kirk (1978) and further developed by Ariskin (1985) and Ariskin et al. (1993 and references therein). In particular, they showed that, theoretically, any mineral of the basaltic association, either olivine, orthopyroxene, clinopyroxene, pigonite, or plagioclase, may be in equilibrium with any basaltic melt but only at one discrete "pseudoliquidus" temperature, which depends mostly on the melt composition and may be different for each particular solid phase. These temperatures can by obtained by calculations using existing models of solid-melt equilibria. Mineral phases having the highest and most similar "pseudoliquidus" temperatures (the difference should be less than $\pm 10^{\circ}-30^{\circ} \mathrm{C}$, depending on the selected model) can be ascribed to equilibrium with such a melt composition. Balance-mass addition into the melt of the phase that is characterized by the lowest "pseudoliquidus" temperature will cause an increase of its "pseudoliquidus" temperature recalculated for the new melt composition. As soon as this temperature becomes higher compared to the temperatures calculated for the other minerals among the association considered for modeling, the next phase char- 
Table 4. $\mathrm{H}_{2} \mathrm{O}$ (wt\%) and trace element (ppm) concentrations in olivine- and clinopyroxene-hosted glass inclusions (uncorrected values).

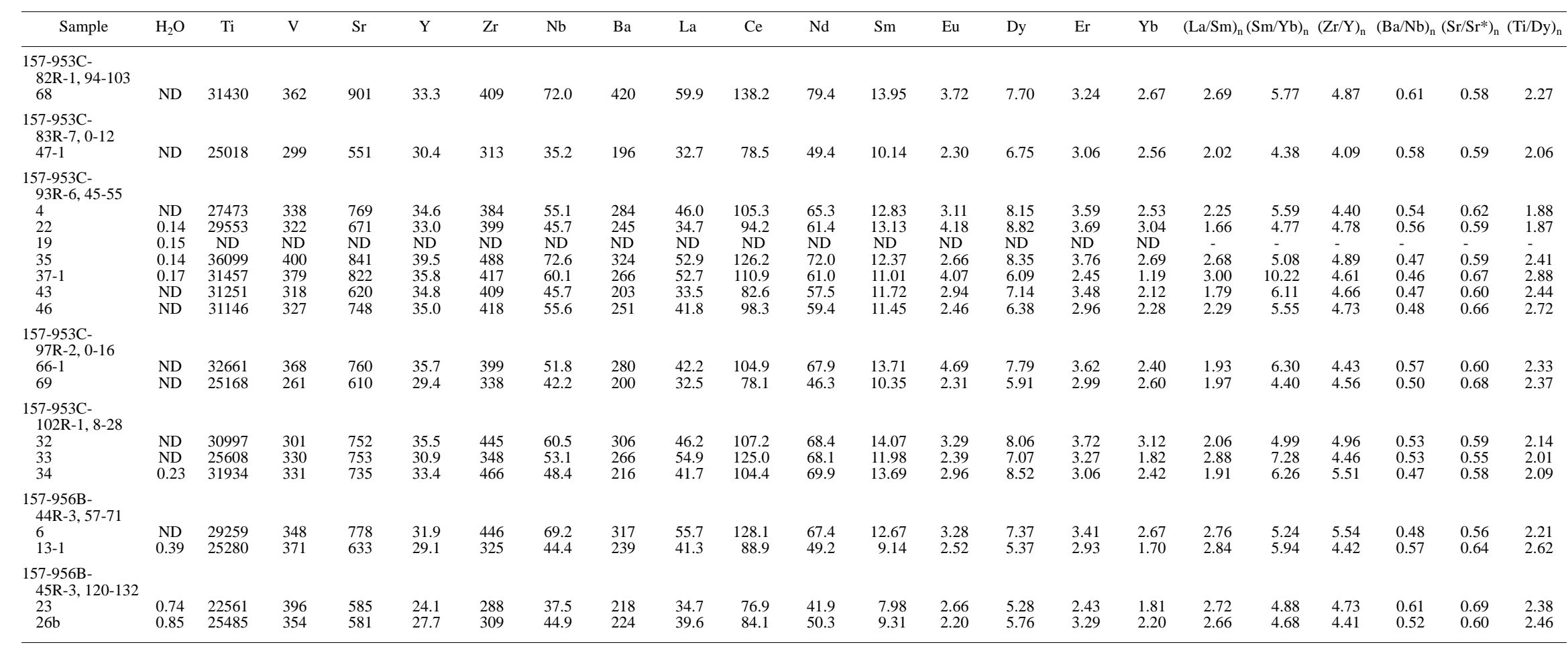

Notes: Sample $=$ sample studied (core, section, interval $[\mathrm{cm}]$, and analyzed grain). ND $=$ not determined, and $-=$ not calculated. $(\mathrm{La} / \mathrm{Sm})_{\mathrm{n}},(\mathrm{Sm} / \mathrm{Yb})_{\mathrm{n}},(\mathrm{Zr} / \mathrm{Y})_{\mathrm{n}},(\mathrm{Ba} / \mathrm{Nb})_{\mathrm{n}},(\mathrm{Sr} / \mathrm{Sr})_{\mathrm{n}}$, and $(\mathrm{Ti} / \mathrm{Dy})_{\mathrm{n}}$ are normalized to CI chondrites $(\mathrm{after}$ Anders and Grevesse, 1989). $\mathrm{Sr} / \mathrm{Sr}^{*}=$ magnitude of the $\mathrm{Sr}$ anomaly on the $\mathrm{REE}$ profile defined as $\mathrm{Sr} /(\mathrm{Ce} \times \mathrm{Nd})^{0.5}$. 
acterized by the lowest temperature begins to be added into the melt. This principle is used, in particular, to model the cotectic melting of olivine and clinopyroxene, being realized in the program PETROLOG for a pressure range from 0.001 to $10 \mathrm{kbar}$.

In our calculations, we used equations of Ford et al. (1983) for olivine-melt equilibria, and of Ariskin et al. (1987) for clinopyroxenemelt equilibria. The $\mathrm{Fe}^{2+} / \mathrm{Fe}^{3+}$ ratio in the calculated melt was deduced from the $\mathrm{Fe}^{2+} / \mathrm{Fe}^{3+}$ ratios of the coexisting spinel inclusions using the experimental data on spinel-silicate melt equilibrium after Maurel and Maurel (1982) with the equation

$$
\log _{10}\left(\mathrm{Fe}^{2+} / \mathrm{Fe}^{3+}\right)_{\mathrm{sp}}=0.764 \times \log _{10}\left(\mathrm{Fe}^{2+} / \mathrm{Fe}^{3+}\right)_{\text {melt }}-0.343, \mathrm{r}=0.96 .
$$

Correction of olivine-hosted inclusions was carried out assuming a lithostatic pressure of $3 \mathrm{kbar}$ inferred from the densities of $\mathrm{CO}_{2}$ fluid inclusions in olivine. Inclusions in clinopyroxene were corrected at the varying pressures $(<0.5-8 \mathrm{kbar})$ inferred for each particular melt inclusion. To estimate the pressure, we used the experimentally defined difference in the slopes of olivine and clinopyroxene liquidus lines obtained for the wide range of temperature and pressure. Indeed, the appearance of olivine and clinopyroxene on the magma liquidus is strongly controlled by a pressure. If, for olivine, the slope of the liquidus line in P-T coordinates was defined to be between $3^{\circ}$ and $5^{\circ} \mathrm{C} /$ kbar, clinopyroxene has a slope of $\sim 10^{\circ} \mathrm{C} / \mathrm{kbar}$ (e.g., Bender et al., 1978; Nisbet, 1982; Ford et al., 1983; Takahashi and Kushiro, 1983; Ariskin et al., 1987). Because all clinopyroxene phenocrysts crystallized on the cotectic with olivine, as follows from the petrographic observations and the presence of olivine inclusions in clinopyroxene, we used this discrepancy $\left(5^{\circ} \mathrm{C} / \mathrm{kbar}\right.$ for olivine and $10^{\circ} \mathrm{C} / \mathrm{kbar}$ for clinopyroxene) to estimate the pressure of their crystallization. We tried to find such a pressure, so that the difference between calculated temperatures of olivine-melt and clinopyroxene-melt equilibria obtained for the same melt composition would be $<5^{\circ} \mathrm{C}$.

The correction procedure could significantly affect concentrations of major elements compatible with olivine and clinopyroxene as, for instance, $\mathrm{Si}, \mathrm{Al}, \mathrm{Fe}, \mathrm{Mg}$, and $\mathrm{Ca}$. Because the selected models of olivine- and clinopyroxene-melt equilibria are not free from uncertainties, concentrations of these elements in the corrected melts should be regarded as preliminary. Further high-temperature microthermometric studies of melt inclusions should be performed to assess whether or not the calculated melt compositions are truly representative for the Miocene picritic and basaltic magmas. On the other hand, the correction procedure for elements highly incompatible with olivine and clinopyroxene (e.g., Ti, Na, K, P, trace elements, and $\mathrm{H}_{2} \mathrm{O}$ ) is nearly a dilution of their measured concentrations by the amounts of olivine and/or clinopyroxene crystallized within the inclusions. In most cases, the amounts of added crystal phase are close to the precision of ion microprobe measurements (10\%-20\% relative). In any case, we always use the corrected concentrations, although the same conclusions could be obtained from the uncorrected minor and trace element values.

\section{Major Elements}

The corrected major element compositions of melt inclusions together with calculated temperatures of their entrapment are listed in Appendix Table 3. Corrected compositions of olivine- and clinopyroxene-hosted melt inclusions were obtained to be similar to each other at the same Mg\# of melt (Fig. 7). This suggests that the models for the applied correction of the post-entrapment crystallization were selected correctly, otherwise one would expect discrepancies in the concentrations of $\mathrm{CaO}$ and $\mathrm{Al}_{2} \mathrm{O}_{3}$, which are compatible with the clinopyroxene structure but are present only as traces in olivine. Corrected compositions of melt inclusions are therefore believed to be representative for the melt composition during phenocryst crystallization. Concentrations of major elements, for example $\mathrm{SiO}_{2}, \mathrm{Al}_{2} \mathrm{O}_{3}$, $\mathrm{FeO}, \mathrm{Na}_{2} \mathrm{O}$, and $\mathrm{K}_{2} \mathrm{O}$, are more variable compared to the Miocene shield basalts on Gran Canaria (Fig. 7). Corrected melt inclusions represent melts whose compositions range from tholeiitic to transitional basalts, whereas melt inclusions in olivine and clinopyroxene from subaerial shield basalts range from transitional to alkaline compositions and are more magnesian (Fig. 8). The bulk compositions of
Figure 7. $\mathrm{MgO}$ variation diagrams for the corrected compositions of melt inclusions in olivine and clinopyroxene. Fields of Miocene shield basalts of Gran Canaria are after Hoernle and Schmincke (1993a; unpubl. data), melt inclusions in olivine are taken from Gurenko et al. (1996). For legend see Figure 5.
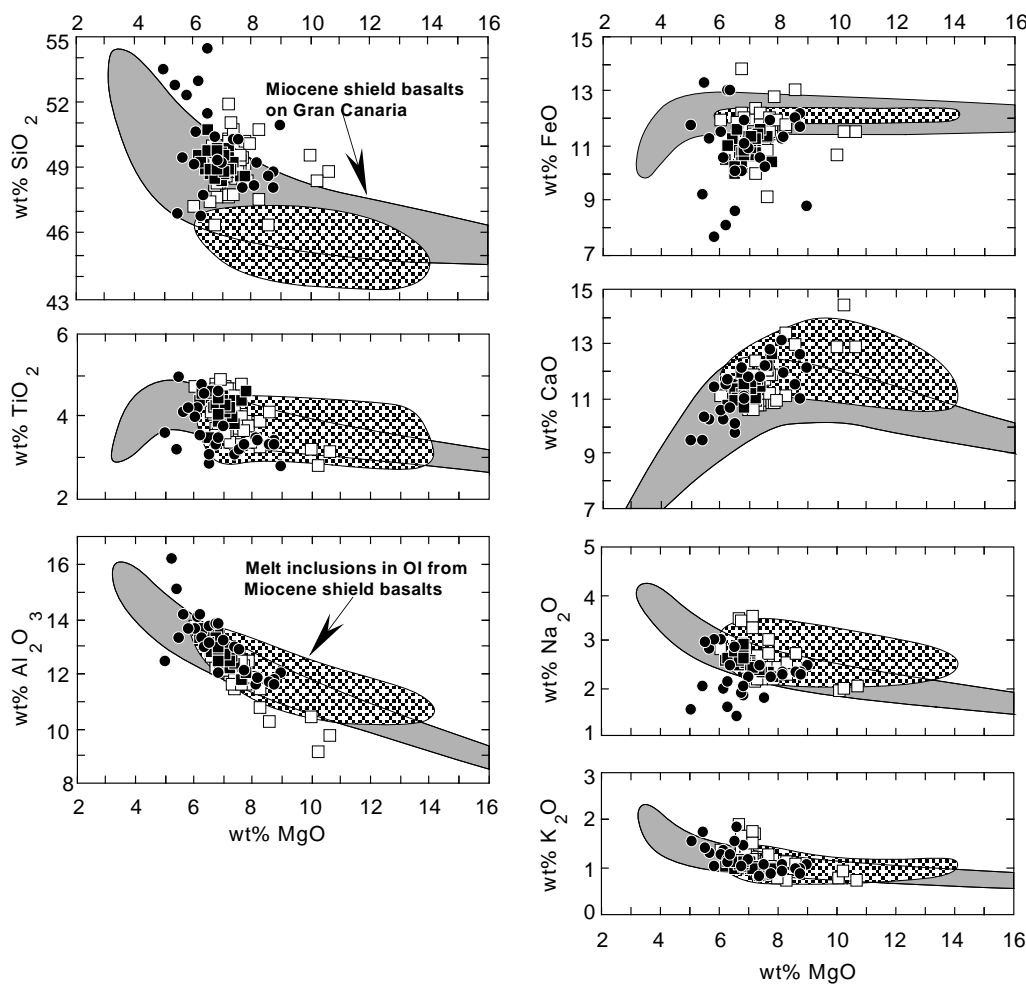
the submarine hyaloclastites are characterized by lower contents of $\mathrm{SiO}_{2}$, probably, because of the alteration (Fig. 8).

$\mathrm{K}_{2} \mathrm{O} / \mathrm{TiO}_{2}$ and $\mathrm{P}_{2} \mathrm{O}_{5} / \mathrm{TiO}_{2}$ ratios of the corrected melt inclusion compositions vary significantly throughout the broad range of $\mathrm{MgO}$ and $\mathrm{SiO}_{2}$ contents $(0.28-0.64$ and $0.09-0.26$, respectively; Fig. 9, Appendix Table 3). The most extreme variations were found in Samples 157-953C-98R-1, 0-12 cm, 82R-1, 52-82 cm, 157-956B-44R$3,57-71 \mathrm{~cm}, 45 \mathrm{R}-3,120-132 \mathrm{~cm}$, and $45 \mathrm{R}-\mathrm{CC}, 7-17 \mathrm{~cm}$. It is unlikely that crystallization of Ti-rich spinel, titanomagnetite, or ilmenite could significantly decrease concentrations of $\mathrm{Ti}$ in the melt resulting in the observed variations of the $\mathrm{K}_{2} \mathrm{O} / \mathrm{TiO}_{2}$ and $\mathrm{P}_{2} \mathrm{O}_{5} / \mathrm{TiO}_{2}$ ratios because (1) titanomagnetite and ilmenite are found as inclusions in low-magnesian clinopyroxene only at $\mathrm{Mg \#}_{\mathrm{cpx}}<0.8$, and (2) inclusions characterized by elevated $\mathrm{K}_{2} \mathrm{O} / \mathrm{TiO}_{2}$ and $\mathrm{P}_{2} \mathrm{O}_{5} / \mathrm{TiO}_{2}$ ratios were found in clinopyroxene with $\mathrm{Mg} \#_{\mathrm{cpx}}$ ranging from 0.80 to 0.85 . We therefore think that the observed compositional spectrum reflects that of the parental magmas.

\section{Trace Elements}

Concentrations of trace elements in clinopyroxene-hosted glass inclusions from Sites 953 and 956 are listed in Table 4, and the values corrected for the effects of post-entrapment crystallization are shown in Figure 10. All inclusions are enriched in light rare earth elements (LREE), have $(\mathrm{La} / \mathrm{Sm})_{\mathrm{n}}$ ratios ranging from 1.7 to 3.0, and are similar to subaerially exposed Miocene shield basalts (Schmincke, 1982; Hoernle and Schmincke, 1993a; Fig. 10). Depletion in heavy rare earth elements (HREE) is more significant $\left((\mathrm{Sm} / \mathrm{Yb})_{\mathrm{n}}=4.4-10.2\right)$ compared to LREE. This discrepancy between $(\mathrm{La} / \mathrm{Sm})_{\mathrm{n}}$ and $(\mathrm{Sm} /$ $\mathrm{Yb})_{\mathrm{n}}$, and high $(\mathrm{Zr} / \mathrm{Y})_{\mathrm{n}}$ ratio ranging from 4.1 to 5.5 indicate strong fractionation of LREE vs. HREE. Taking into account the significant difference in solid-liquid distribution coefficients between LREEs and HREEs assumed for garnet (e.g., Green at al., 1989; Kelemen et al., 1993; Jenner et al., 1994), this discrepancy indicates the presence

A
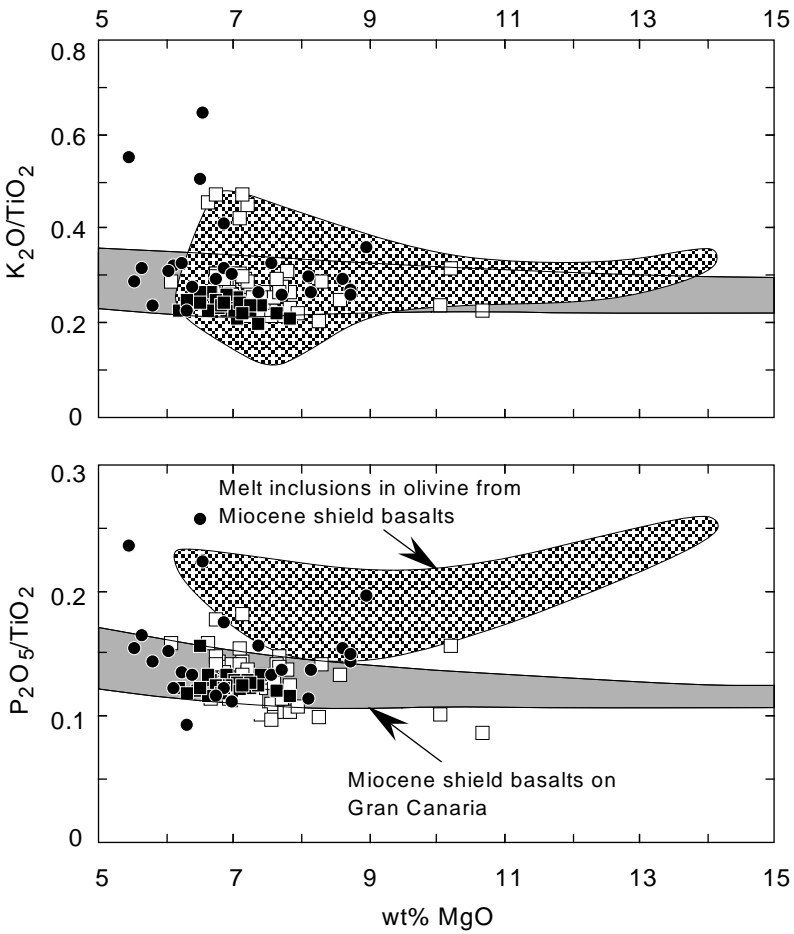

of garnet in the mantle source of Miocene shield basalts, as suggested by Schmincke (1982) and Hoernle and Schmincke (1993a, 1993b) for the Miocene subaerial shield basalts based on major and trace elements in the whole rocks.

Another feature of the trace element compositions of melt inclusions is strong negative $\mathrm{Ba}$ and $\mathrm{Sr}$ anomalies and a positive $\mathrm{Ti}$ anomaly, which are also present in the trace element spectra of the subaerial shield basalts (Fig. 10). Their magnitudes vary very little, as shown by $(\mathrm{Ba} / \mathrm{Nb})_{\mathrm{n}}(0.5-0.6),\left(\mathrm{Sr} / \mathrm{Sr}^{*}\right)_{\mathrm{n}}(0.6-0.7)$, and $(\mathrm{Ti} / \mathrm{Dy})_{\mathrm{n}}(1.9-$ 2.9) ratios (Table 4 ), and correlate neither with the melt enrichment

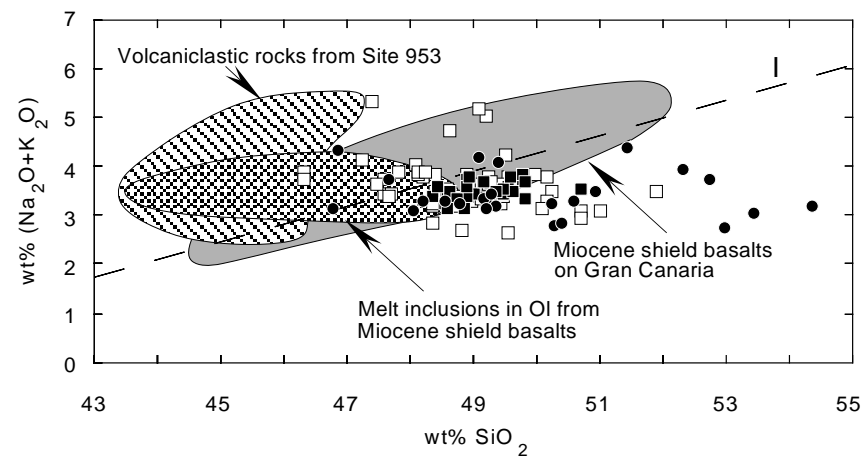

Figure 8. $\left(\mathrm{Na}_{2} \mathrm{O}+\mathrm{K}_{2} \mathrm{O}\right)$ vs. $\mathrm{SiO}_{2}$ in olivine- and clinopyroxene-hosted melt inclusions corrected for post-entrapment crystallization (see text). Field of the Miocene shield basalts on Gran Canaria is after Hoernle and Schmincke (1993a), field of submarine volcaniclastic rocks from Site 953 is after Schmincke, Weaver, Firth, et al. (1995b). Melt inclusions show a compositional range from quartz-normative tholeiitic to transitional basalts. Hyaloclastites at Site 953 are characterized by lower contents of $\mathrm{SiO}_{2}$ resulting from the post-eruptive rock alteration. Dividing line $(I)$ is after Macdonald and Katsura (1964). For legend see Figure 5.
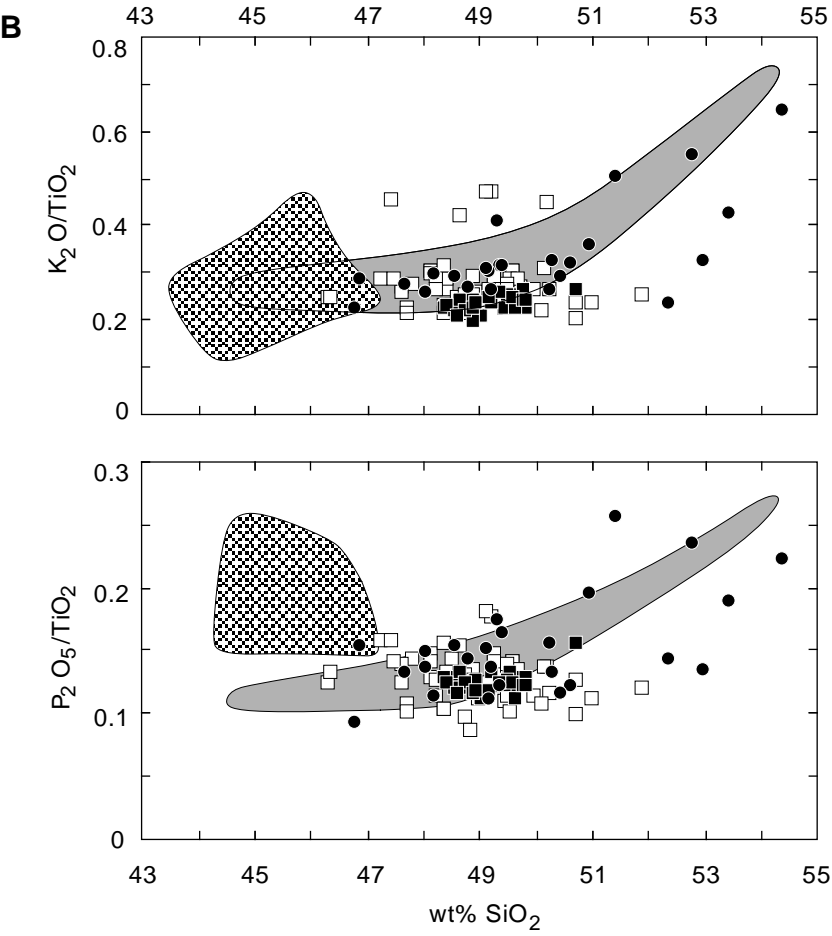

Figure 9. Variations of $\mathrm{K}_{2} \mathrm{O} / \mathrm{TiO}_{2}$ and $\mathrm{P}_{2} \mathrm{O}_{5} / \mathrm{TiO}_{2}$ ratios in melt inclusions. A. $\mathrm{K}_{2} \mathrm{O} / \mathrm{TiO}_{2}$ and $\mathrm{P}_{2} \mathrm{O}_{5} / \mathrm{TiO}_{2}$ vs. $\mathrm{MgO}, \mathbf{B} . \mathrm{K}_{2} \mathrm{O} / \mathrm{TiO} \mathrm{O}_{2}$ and $\mathrm{P}_{2} \mathrm{O}_{5} / \mathrm{TiO} \mathrm{O}_{2}$ vs. SiO . Because the variations of $\mathrm{K}_{2} \mathrm{O} / \mathrm{TiO}_{2}$ and $\mathrm{P}_{2} \mathrm{O}_{5} / \mathrm{TiO}_{2}$ ratios cannot be explained by crystallization, the observed compositional spectrum reflects that of the parental magmas. For legend see Figure 5. 
A

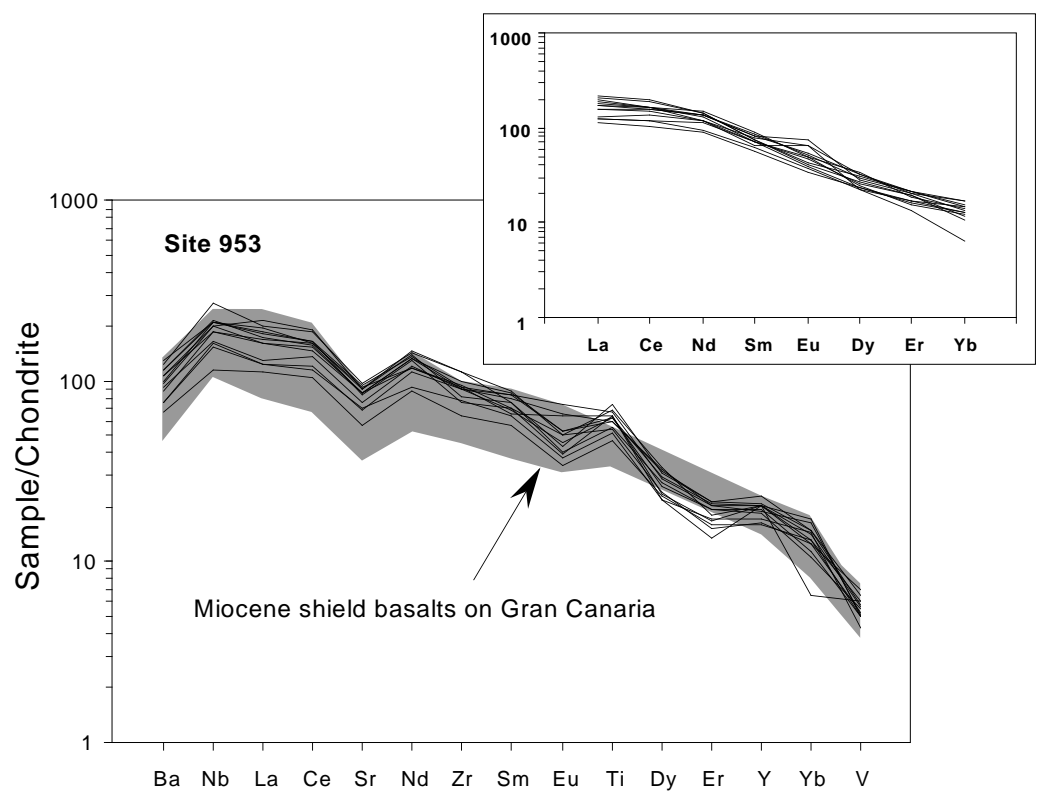

B

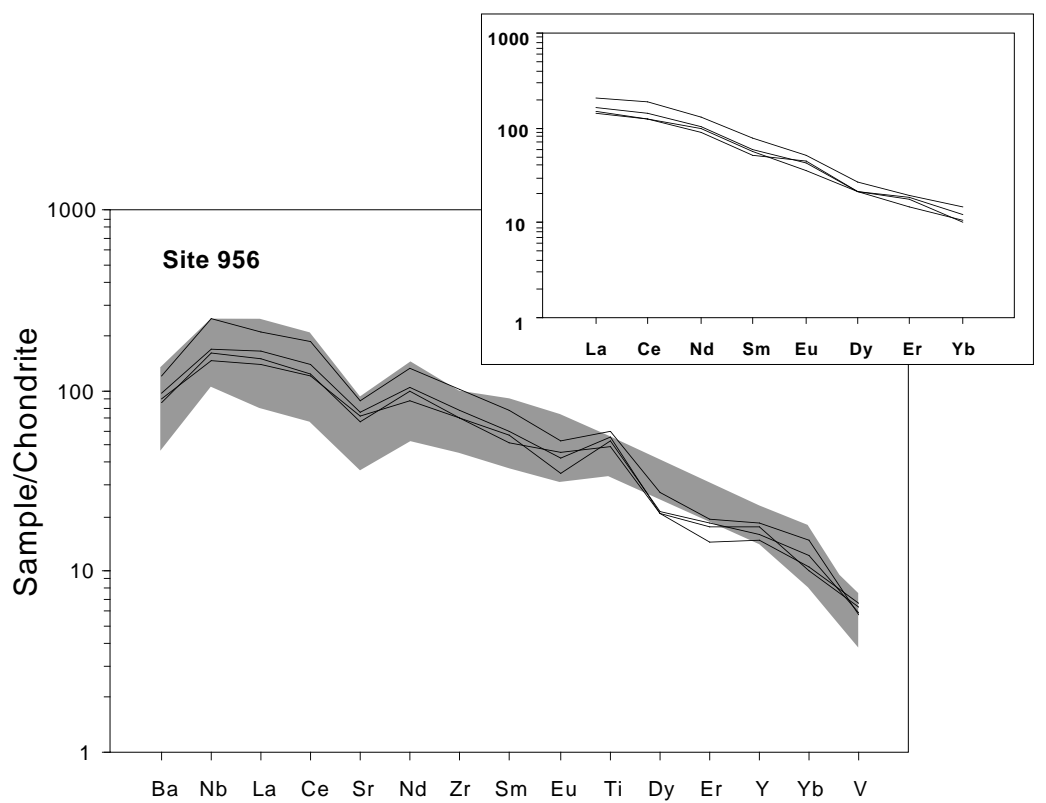

Figure 10. Trace element patterns of olivine- and clinopyroxene-hosted melt inclusions corrected for the effects of post-entrapment crystallization and normalized to chondrites after Anders and Grevesse (1989). A. Site 953. B. Site 956. The insets represent concentrations of rare earth elements. Field of Gran Canaria Miocene shield lavas are from Schmincke (1982) and Hoernle and Schmincke (1993a). Melt inclusions exhibit the concentrations of trace elements similar to those of subaerially exposed shield basalts. Strong negative Ba and $\mathrm{Sr}$ anomalies and a positive Ti anomaly are thought to reflect the composition of the Miocene mantle source beneath Gran Canaria.

factor (e.g., $[\mathrm{La} / \mathrm{Sm}]_{\mathrm{n}}$ ) nor between each other. Absence of either a positive or negative Eu anomaly in the rare earth element (REE) patterns (only two melt inclusions from Site 953 and one inclusion from Site 956 exhibit slightly positive Eu anomaly), and the presence of the $\mathrm{Ba}$ and $\mathrm{Sr}$ anomalies argues against substantial plagioclase fractionation or accumulation, as also concluded by Hoernle and Schmincke (1993a). Schmincke and Flower (1974) and Hoernle and Schmincke (1993b) also argue that phlogopite and ilmenite might be residual to high degrees of melting in the Miocene source. The observed $\mathrm{Ba}, \mathrm{Sr}$, and $\mathrm{Ti}$ anomalies could therefore be ascribed to the composition of the mantle source that produced the Miocene magmas of the submarine to emergent stage of Gran Canaria.

\section{$\mathrm{H}_{2} \mathrm{O}$ Concentrations}

Measured $\mathrm{H}_{2} \mathrm{O}$ concentrations in olivine- and clinopyroxenehosted melt inclusions are listed in Table 4, and their corrected values are presented in Figure 11. All individual inclusion-bearing crystals were carefully examined to avoid inclusions transected by cracks, which may have resulted in loss of the dissolved in the melt volatiles during syn- or post-eruptive cracking of the host mineral. Inclusions in phenocrysts from hyaloclastites (Samples 157-953C-102R-1, 8$28 \mathrm{~cm}$, and 98R-1, 0-12 cm) and basalt fragments (Sample 157953C-93R-6, 45-55 cm) of Site 953 have systematically lower $\mathrm{H}_{2} \mathrm{O}$ concentrations (0.14-0.23 wt\%) compared to inclusions in clinopy- 
roxene in hyaloclastites from Site $956(0.39-0.85 \mathrm{wt} \%$; Samples $157-$ 956B-44R-3, 57-71 cm, and 45R-3, 120-132 cm). These low $\mathrm{H}_{2} \mathrm{O}$ concentrations correspond to or are even lower compared to the concentrations of $\mathrm{H}_{2} \mathrm{O}$ defined for mid-ocean ridge basalts (MORB) and oceanic island basalt magmas (e.g., Moore 1970; Byers et al., 1985; Garcia et al. 1989; Jambon and Zimmermann, 1990; Muenow et al., 1990; Michael, 1995; Sobolev and Chaussidon, 1996), and are very close to the $\mathrm{H}_{2} \mathrm{O}$ concentrations for melt inclusions in olivine from subaerial shield basalts of Gran Canaria reported by Gurenko et al. (1996; Fig. 11).

Magmas parental to the submarine hyaloclastites thought to have erupted below sea level are unlikely to have been subjected to the high degrees of degassing, as expected for the subaerially exposed basalts. Although leakage of water through the surrounding olivine or clinopyroxene may occur, the $\mathrm{H}_{2} \mathrm{O}$ concentrations in melt inclusions from submarine hyaloclastites are expected to be better estimates of primary $\mathrm{H}_{2} \mathrm{O}$ concentrations than those of subaerally erupted lavas and quenched glasses as shown by Sobolev and Chaussidon (1996). The hyaloclastites from Site 956 represent more evolved compositions and are stratigraphically correlated to the late more evolved Hogarzales basalts on Gran Canaria (Schmincke and Segschneider, Chap. 12, this volume), thus suggesting that $\mathrm{H}_{2} \mathrm{O}$ concentrations increased significantly during evolution of the basaltic magmas. Alternatively, the observed $\mathrm{H}_{2} \mathrm{O}$ scatter can be ascribed to either deepseated degassing or heterogeneity of the mantle source beneath the Canary Islands.

\section{PARENTAL MAGMAS}

\section{Composition of Parental Magmas}

The observed compositional variations in melt inclusions corrected for the post-entrapment crystallization are likely to be similar to

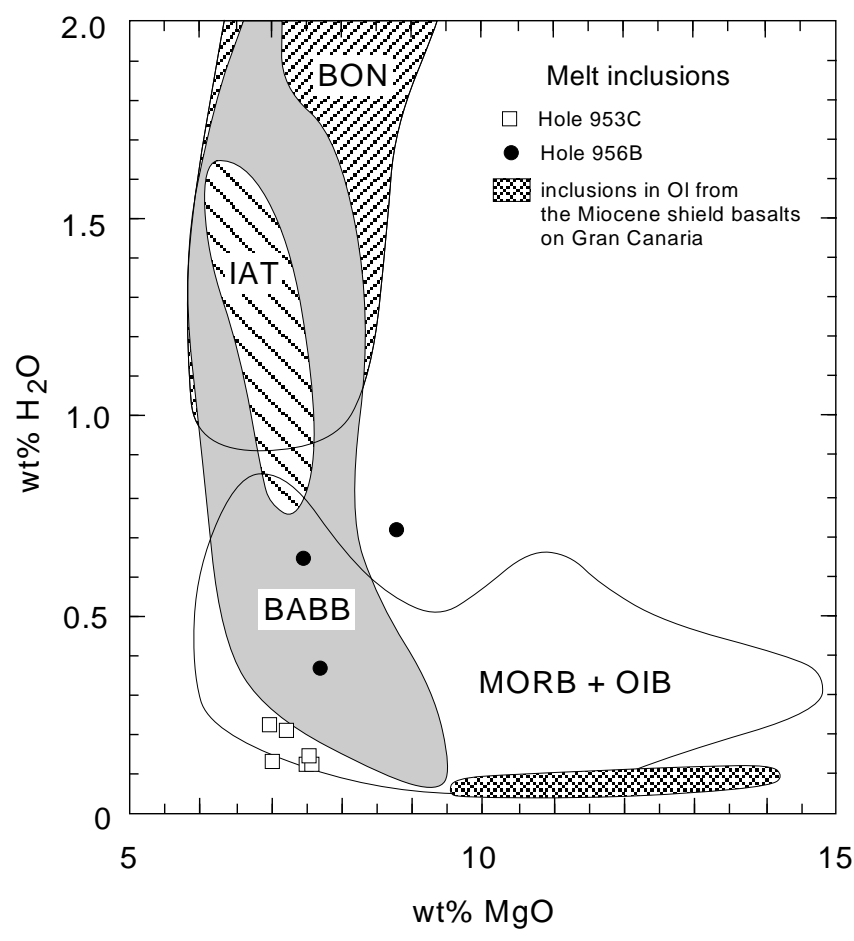

Figure 11. Concentrations of $\mathrm{H}_{2} \mathrm{O}$ in melt inclusions vs. $\mathrm{MgO}$. Reference fields are submarine glasses containing $>6 \mathrm{wt} \% \mathrm{MgO}$ and taken from Sobolev and Chaussidon (1996). MORB = mid-ocean ridge basalts, OIB = oceanic island basalts, IAT $=$ island arc tholeiites, and $\mathrm{BON}=$ boninites. Inclusions in olivine from the Miocene shield basalts on Gran Canaria are taken from Gurenko et al. (1996). chemical variations in their parental magmas, rather than a result of low-pressure crystallization of a single magma type. This follows from the strong variations of $\mathrm{SiO}_{2}$ concentrations and relatively constant concentrations of alkalis and the observed scatter of $\mathrm{K}_{2} \mathrm{O} / \mathrm{TiO}_{2}$ and $\mathrm{P}_{2} \mathrm{O}_{5} / \mathrm{TiO}_{2}$ ratios throughout the broad range of $\mathrm{MgO}$ and $\mathrm{SiO}_{2}$ (Figs. 8, 9). These variations cannot be explained by magma crystallization in shallow reservoirs only because (1) crystallization of olivine, clinopyroxene, and minor plagioclase would cause an enrichment of the evolving melt by both silica and alkalis, and (2) $\mathrm{K}_{2} \mathrm{O} / \mathrm{TiO}_{2}$ and $\mathrm{P}_{2} \mathrm{O}_{5} / \mathrm{TiO}_{2}$ ratios should remain constant. Additionally, strong variations of $\mathrm{FeO}$ at the nearly constant $\mathrm{MgO}$ (Fig. 7), which cannot be explained by crystallization of spinel or titanomagnetite, but suggest a spectrum of parental magmas which, probably, resulted from a polybaric melting process. As shown by numerous experimental studies (e.g., Jaques and Green, 1980; Stolper, 1980; Falloon and Green, 1988; Kinzler and Grove, 1993; Hirose and Kushiro, 1993), partial melts that originated at higher pressures should have higher $\mathrm{FeO}$ contents compared to those in the melts originated at lower pressures. In contrast, $\mathrm{FeO}$ content of a melt is little affected by the degree of melting at a constant pressure. In the case of naturally quenched inclusions of glass, one would not expect a post-entrapment diffusion of Fe from the melt into the matrix of the host mineral as shown for recrystallized inclusions in olivine from Miocene subaerial shield basalts (Gurenko et al., 1996). The observed range of major element concentrations in the melt inclusions is believed to be due to the chemical variations of their parental magmas.

Compositions of parental magmas were obtained by simulating the olivine and clinopyroxene melting using the corrected major element compositions of melt inclusions. We used a similar calculation routine applied for the compositional correction of the post-entrapment crystallization (see above). The calculations were carried out in two steps. First, we modeled the melting of both olivine and clinopyroxene as cotectic phases until the composition of calculated melt became equilibrated with the most magnesian clinopyroxene found in each particular sample (given in Table 3). Second, we modeled the melting of olivine only, using the melt compositions obtained during the first step. The calculation routine was aborted as soon as the melt was in equilibrium with olivine $\mathrm{Fo}_{90}$, the most magnesian olivine phenocrysts found in Miocene shield basalts of Gran Canaria (Gurenko et al., 1996).

Compositions of the calculated parental magmas are listed in Table 5. Parental magmas are high magnesian, similar to olivine basalts-picrites (12.4-18.0 wt\% MgO for hyaloclastites from Site 953, and 11.2-15.6 wt\% MgO for Site 956) and represent a spectrum from transitional to tholeiitic compositions $\left(46.7-50.0 \mathrm{wt} \% \mathrm{SiO}_{2}\right.$ for Site 953, and 48.7-52.0 wt\% $\mathrm{SiO}_{2}$ for Site 956). This is a broad range, but the variations within the restricted samples are less significant (Table 5). The most magnesian parental magma compositions are very close to picritic primary magmas proposed for the subaerial Miocene shield basalts on Gran Canaria (Schmincke, 1982; Hoernle and Schmincke, 1993a; Gurenko et al., 1996), as well as to primary magmas obtained for Hawaiian shield tholeiites (18.5-21.0 wt\% $\mathrm{MgO}, 48.0-49.3$ wt\% $\mathrm{SiO}_{2}$ ) by Sobolev and Nikogosian (1994), except that the observed variations in $\mathrm{SiO}_{2}$ contents for the reported parental magmas are more significant.

We interpret the observed variations in parental magma compositions as reflecting a temporal evolution of the mantle plume. Transitional magmas are supposed to have formed at the beginning of plume activity (seamount stage), followed by tholeiitic magmas produced at higher degrees of melting (end of the seamount shield stage and begin of the subaerial). Alkali basalt magmas exposed on Gran Canaria (Guigui Formation) described by Gurenko et al. (1996) may represent a termination of this cycle of magma generation activity. Our interpretation fits well with the "blob" model proposed for the Canary Islands by Hoernle and Schmincke (1993b) and with the temporal evolution inferred for the history of the Hawaiian mantle plume (e.g., Wyllie, 1988; Rhodes and Hart, 1995). 
Table 5. Calculated compositions of parental magmas.

\begin{tabular}{|c|c|c|c|c|c|c|c|c|c|c|c|c|c|}
\hline Sample & $\mathrm{SiO}_{2}$ & $\mathrm{TiO}_{2}$ & $\mathrm{Al}_{2} \mathrm{O}_{3}$ & $\mathrm{Fe}_{2} \mathrm{O}_{3}$ & $\mathrm{FeO}$ & $\mathrm{MnO}$ & $\mathrm{MgO}$ & $\mathrm{CaO}$ & $\mathrm{Na}_{2} \mathrm{O}$ & $\mathrm{K}_{2} \mathrm{O}$ & $\mathrm{P}_{2} \mathrm{O}_{5}$ & $\mathrm{~T}\left({ }^{\circ} \mathrm{C}\right)$ & $\lg f_{\mathrm{O} 2}$ \\
\hline \multicolumn{14}{|c|}{$\begin{array}{l}157-953 \mathrm{C}- \\
82 \mathrm{R}-1,52-82\end{array}$} \\
\hline & 47.8 & 2.5 & 8.1 & 0.9 & 8.6 & 0.09 & 13.0 & 11.0 & 1.8 & 0.8 & 0.4 & 1353 & -7.7 \\
\hline Max & 49.2 & 2.7 & $\begin{array}{l}9.1 \\
9.6\end{array}$ & 1.0 & 9.7 & 0.13 & 14.4 & 13.3 & 2.4 & 1.2 & 0.4 & 1404 & -7.2 \\
\hline Mean & 48.6 & 2.5 & 8.9 & 1.0 & 9.2 & 0.11 & 13.9 & 12.2 & 2.2 & 1.0 & 0.4 & 1374 & -7.5 \\
\hline \multicolumn{14}{|c|}{$\begin{array}{l}157-953 \mathrm{C}- \\
82 \mathrm{R}-1,94-103\end{array}$} \\
\hline Min & 47.1 & 2.3 & 7.2 & 0.9 & 8.2 & 0.09 & 12.4 & 11.9 & 1.6 & 0.7 & 0.4 & 1340 & -7.8 \\
\hline $\operatorname{Max}$ & 49.1 & 3.8 & 9.7 & 1.1 & 10.4 & 0.13 & 15.7 & 12.9 & 2.4 & 1.0 & 0.5 & 1418 & -7.1 \\
\hline Mean & 47.9 & 2.9 & 8.1 & 1.0 & 9.6 & 0.11 & 14.5 & 12.5 & 1.9 & 0.8 & 0.4 & 1386 & -7.4 \\
\hline \multicolumn{14}{|l|}{$\begin{array}{l}157-953 \mathrm{C}- \\
83 \mathrm{R}-7,0-12\end{array}$} \\
\hline Min & 48.2 & 2.4 & 8.6 & 1.1 & 10.8 & 0.10 & 17.1 & 8.9 & 1.7 & 0.5 & 0.2 & 1419 & -6.7 \\
\hline Max & 48.5 & 2.4 & 8.7 & 1.2 & 10.9 & 0.11 & 17.2 & 9.0 & 1.7 & 0.5 & 0.3 & 1421 & -6.7 \\
\hline Mean & 48.3 & 2.4 & 8.6 & 1.1 & 10.8 & 0.11 & 17.1 & 9.0 & 1.7 & 0.5 & 0.2 & 1420 & -6.7 \\
\hline \multicolumn{14}{|l|}{$\begin{array}{l}157-953 \mathrm{C}- \\
89 \mathrm{R}-1,0-13\end{array}$} \\
\hline Min & 47.9 & 2.2 & 8.0 & 1.0 & 9.0 & 0.09 & 13.8 & 11.3 & 1.6 & 0.6 & 0.2 & 1359 & -7.6 \\
\hline & 49.2 & 2.6 & 9.4 & 1.1 & 10.3 & 0.11 & 16.4 & 12.6 & 1.9 & 0.7 & 0.3 & 1431 & -6.9 \\
\hline Mean & 48.7 & 2.4 & 8.9 & 1.0 & 9.5 & 0.10 & 14.7 & 12.0 & 1.7 & 0.6 & 0.3 & 1379 & -7.3 \\
\hline \multicolumn{14}{|c|}{$\begin{array}{l}157-953 \mathrm{C}- \\
90 \mathrm{R}-1,82-101\end{array}$} \\
\hline Min & 46.7 & 2.5 & 8.7 & 1.1 & 9.9 & 0.11 & 15.2 & 8.7 & 1.6 & 0.6 & 0.3 & 1388 & -7.1 \\
\hline Max & 48.3 & 3.0 & 9.9 & 1.2 & 11.5 & 0.13 & 18.0 & 9.7 & 2.0 & 0.8 & 0.4 & 1447 & -6.4 \\
\hline Mean & 47.4 & 2.8 & 9.4 & 1.1 & 10.6 & 0.12 & 16.4 & 9.4 & 1.8 & 0.7 & 0.3 & 1410 & -6.8 \\
\hline \multicolumn{14}{|c|}{$\begin{array}{l}\text { 157-953C- } \\
93 \mathrm{R}-6,45-55\end{array}$} \\
\hline Min & 47.6 & 2.6 & 8.9 & 1.0 & 9.3 & 0.07 & 14.3 & 10.0 & 1.6 & 0.5 & 0.3 & 1367 & -7.3 \\
\hline Max & 49.1 & 3.6 & 10.2 & 1.1 & 10.4 & 0.12 & 16.0 & 11.1 & 1.9 & 0.8 & 0.4 & 1395 & -7.0 \\
\hline Mean & 48.1 & 3.0 & 9.4 & 1.0 & 9.8 & 0.10 & 15.1 & 10.6 & 1.7 & 0.7 & 0.4 & 1379 & -7.2 \\
\hline \multicolumn{14}{|l|}{$\begin{array}{l}157-953 \mathrm{C}- \\
97 \mathrm{R}-2,0-16\end{array}$} \\
\hline Min & 47.1 & 2.6 & 8.3 & 1.0 & 9.4 & 0.07 & 14.5 & 9.3 & 1.5 & 0.6 & 0.3 & 1370 & -7.3 \\
\hline Max & 50.0 & 3.1 & 9.8 & 1.1 & 10.6 & 0.14 & 16.8 & 10.8 & 2.0 & 0.8 & 0.4 & 1415 & -6.8 \\
\hline Mean & 48.3 & 2.8 & 9.0 & 1.1 & 10.2 & 0.12 & 15.7 & 10.1 & 1.7 & 0.7 & 0.3 & 1390 & $\begin{array}{l}-0.0 \\
-7.1\end{array}$ \\
\hline \multicolumn{14}{|l|}{$\begin{array}{l}157-953 \mathrm{C}- \\
98 \mathrm{R}-1.0-12\end{array}$} \\
\hline Min & 46.7 & 2.7 & 8.6 & 1.1 & 10.0 & 0.08 & 15.5 & 8.9 & 1.6 & 0.6 & 0.3 & 1391 & -7.0 \\
\hline Max & 48.3 & 3.4 & 9.8 & 1.2 & 10.9 & 0.16 & 17.2 & 10.0 & 2.0 & 1.3 & 0.4 & 1431 & -6.6 \\
\hline Mean & 47.6 & 3.0 & 9.3 & 1.1 & 10.4 & 0.11 & 16.0 & 9.5 & 1.8 & 0.8 & 0.4 & 1403 & -6.9 \\
\hline \multicolumn{14}{|c|}{$\begin{array}{l}157-953 \mathrm{C}- \\
102 \mathrm{R}-1,8-28\end{array}$} \\
\hline Min & 46.8 & 2.9 & 8.7 & 1.1 & 9.8 & 0.10 & 15.1 & 9.0 & 1.6 & 0.7 & 0.4 & 1385 & -7.2 \\
\hline $\operatorname{Max}$ & 48.1 & 3.4 & 9.7 & 1.1 & 10.8 & 0.15 & 16.8 & 10.9 & 1.9 & 0.9 & 0.5 & 1429 & -6.7 \\
\hline Mean & 47.4 & 3.1 & 9.2 & 1.1 & 10.3 & 0.12 & 15.8 & 10.0 & 1.8 & 0.8 & 0.4 & 1398 & -7.0 \\
\hline \multicolumn{14}{|c|}{$\begin{array}{l}\text { 157-956B- } \\
44 \mathrm{R}-3,57-71\end{array}$} \\
\hline Min & 48.7 & 2.1 & 8.4 & 0.9 & 8.2 & 0.08 & 13.3 & 9.2 & 1.0 & 0.6 & 0.3 & 1334 & -7.6 \\
\hline $\operatorname{Max}$ & 52.2 & 2.9 & 11.2 & 1.1 & 9.9 & 0.13 & 15.2 & 11.8 & 1.7 & 1.4 & 0.5 & 1366 & -7.3 \\
\hline Mean & 49.9 & 2.5 & 10.0 & 1.0 & 9.0 & 0.10 & 14.2 & 10.7 & 1.3 & 0.9 & 0.4 & 1349 & -7.5 \\
\hline \multicolumn{14}{|c|}{$\begin{array}{l}157-956 \mathrm{~B}- \\
45 \mathrm{R}-3,120-132\end{array}$} \\
\hline Min & 48.7 & 2.1 & 8.4 & 0.8 & 7.2 & 0.09 & 11.3 & 11.6 & 1.2 & 0.5 & 0.3 & 1272 & -8.3 \\
\hline Max & 52.0 & 2.7 & 11.4 & 1.0 & 9.7 & 0.13 & 15.6 & 14.4 & 2.0 & 0.9 & 0.5 & 1409 & -7.1 \\
\hline Mean & 49.7 & 2.3 & 9.3 & 0.9 & 8.7 & 0.11 & 13.5 & 13.0 & 1.4 & 0.7 & 0.3 & 1341 & -7.7 \\
\hline \multicolumn{14}{|c|}{$\begin{array}{l}\text { 157-956B- } \\
\text { 45R-CC, 7-17 }\end{array}$} \\
\hline $\begin{array}{l}45 \mathrm{~K}-\mathrm{CC}, 7- \\
\text { Min }\end{array}$ & 49.9 & 2.2 & 9.8 & 0.8 & 7.4 & 0.14 & 11.2 & 9.6 & 2.0 & 0.8 & 0.5 & 1289 & -8.2 \\
\hline $\operatorname{Max}$ & 51.0 & 3.5 & 11.5 & 1.0 & 9.2 & 0.16 & 14.6 & 10.6 & 2.4 & 1.1 & 0.6 & 1382 & -7.2 \\
\hline Mean & 50.5 & 2.8 & 10.7 & 0.9 & 8.3 & 0.15 & 12.9 & 10.1 & 2.2 & 1.0 & 0.5 & 1336 & -7.7 \\
\hline
\end{tabular}

Note: Sample $=$ sample studied $($ core, section, interval $[\mathrm{cm}])$. Min $=$ minimum, Max $=$ maximum, and Mean $=$ average values of major element concentrations obtained on the basis of olivine- and clinopyroxene-hosted inclusions of glass from the each sample studied.

The occurrence of a wide spectrum of magma compositions as inclusions in olivine and clinopyroxene, even within single specimens, is striking, thus suggesting two possibilities of parental magma origin. First, melt inclusions are likely to have preserved melts formed through crystallization of distinct primary melt batches, whereas the erupted magmas seem to represent an integrated mixture of these melts. These primary instantaneous melts are likely to have migrated separately to shallower magma reservoirs without significant interaction with lithospheric upper mantle and/or crustal rocks, perhaps via the channel-segregation melting model proposed for Hawaii by Eggins (1992). Subsequent crystallization of less magnesian olivine, clinopyroxene and plagioclase phenocrysts may have occurred in magma reservoirs filled by these primary (or near-primary) magmas or by their mixtures. Second, the most silica-rich parental magmas (observed only in hyaloclastites from Site 956) can also be interpreted as resulting from re-equilibration or contamination of primitive melts formed at greater depths during their migration through the lithosphere, whose thickness beneath Gran Canaria is expected to be $\approx 80 \mathrm{~km}$, to the shallower magma reservoirs.

\section{Temperature and Pressure of Magma Crystallization}

Calculated temperatures of parental magmas equilibrated with olivine $\mathrm{Fo}_{90}$ show a wide range of temperatures $\left(1340^{\circ}-1450^{\circ} \mathrm{C}\right.$ for 
Site 953 and $1270^{\circ}-1410^{\circ} \mathrm{C}$ for Site 956). Temperature of melt inclusion trapping (i.e., phenocryst crystallization) correlates positively with the composition of the host olivine and clinopyroxene and range from $1120^{\circ}$ to $1290^{\circ} \mathrm{C}$. This broad range of temperatures is close to the temperature of magma crystallization obtained for subaerial shield basalts on Gran Canaria (1490-1150 ${ }^{\circ}$; Gurenko et al., 1996) and for Hawaiian shield stage parental magmas $\left(1420^{\circ}-1180^{\circ} \mathrm{C}\right.$; Sobolev and Nikogosian, 1994; Fig. 12A, B).

The fluid pressure (between 1 and $3 \mathrm{kbar}$ ) was estimated for Sample $157-953 \mathrm{C}-93 \mathrm{R}-5,13-27 \mathrm{~cm}$, and 93R-6, 45-55 cm, calculating the isochores for primary $\mathrm{CO}_{2}$ fluid inclusions. Isochores for the $\mathrm{CO}_{2}$ system were calculated with the modified Redlich-Kwong equation of state after the model of Kerrick and Jacobs (1981) (program FLINCOR; Brown, 1989) using the obtained densities of fluid inclusions $\left(0.28-0.61 \mathrm{~g} / \mathrm{cm}^{3}\right)$ and temperature range of $1100-1250^{\circ} \mathrm{C}$. This estimate represents a lower limit of the pressure of magma crystallization because we cannot exclude the possibility of decrepitation and concomitant crack-healing of fluid inclusions during magma ascent. The pressure of $3 \mathrm{kbar}$ seems to be realistic because a close value of $4.5 \mathrm{kbar}$ was obtained for one clinopyroxene-hosted melt inclusion from the Sample 157-953C-93R-6, 45-55 cm, during the correction of post-entrapment crystallization (Appendix Table 3). Alternatively, if the low-density fluid inclusions do not represent inclusions decrepitated during the magma assent, the lowest pressures of $1 \mathrm{kbar}$ might correspond to a crustal holding reservoir for the large-volume shield basalts.

Pressure of clinopyroxene crystallization estimated during the correction of post-entrapment crystallization (see above) shows a wide range from $<0.5$ to $8 \mathrm{kbar}$ (Fig. 12B). In contrast to the temperatures showing a good correlation with olivine and clinopyroxene compositions, pressure does not correlate at all. Taking into account that most of clinopyroxene crystals are strongly normally and inversely zoned, this implies that growing crystals could interact with melts of significantly different composition reflecting the dynamics of melt migration and storage in several magma reservoirs located at lower crustal to even upper mantle depths. Phenocrysts of more primitive magmas might be expected to have formed at greater pressures, as it may be seen for clinopyroxenes of Mg\# >0.87 (Fig. 12B). The majority of the clinopyroxene phenocrysts with $\mathrm{Mg \#}$ ranging from 0.79 to 0.86 crystallized at pressures of $1-5 \mathrm{kbar}$, thereby reflecting the depths of magma reservoirs located between the appropriate depth of the Moho beneath the Canary Islands $(15 \mathrm{~km})$ and the upper crust.

\section{Redox Conditions}

Redox conditions of magma crystallization were deduced for the entire range of temperature and melt composition based on the models of Sack et al (1980), Kilinc et al. (1983), and Borisov and Shapkin (1990), using the calculated temperatures, $\mathrm{Fe}^{2+} / \mathrm{Fe}^{3+}$ ratios, and major element compositions of the corrected melt inclusions and calculated parental magmas. Calculated values of oxygen fugacity (average and $\pm 1 \sigma$ ) are listed in Appendix Table 3 and plotted in Figure 12. These three models are in good agreement between one another, so that $1 \sigma$ does not exceed $\pm 0.4 \log$ unit, although the uncertainty of the method is estimated to be better than $0.7 \log$ unit.

Although the calculated parental magmas show a significant compositional range (Table 5), their early crystallization defined for both Sites 953 and 956 occurred at redox conditions similar to FMQ-1 or WM- 1 and correspond to those obtained for the primitive subaerial shield magmas of Gran Canaria and Hawaii (e.g., Sobolev and Nikogosian, 1994; Gurenko et al., 1996; Fig. 13). Further crystallization of parental magmas is likely to have been accompanied by progressive oxidation up to the conditions corresponding to the FMQ-NNO buffers in case of hyaloclastites from Site 953, and up to the $\mathrm{NNO}+0.5-\mathrm{NNO}+1$ conditions in case of Site 956 , the same $f_{\mathrm{o}_{2}}$ con-
A

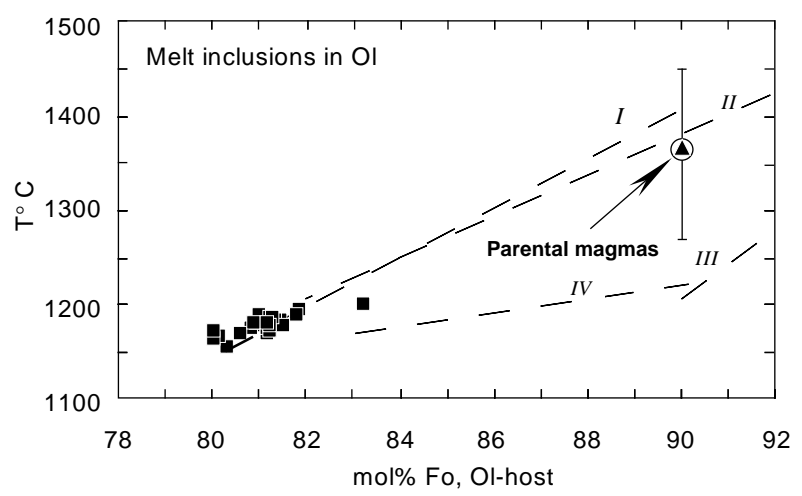

B
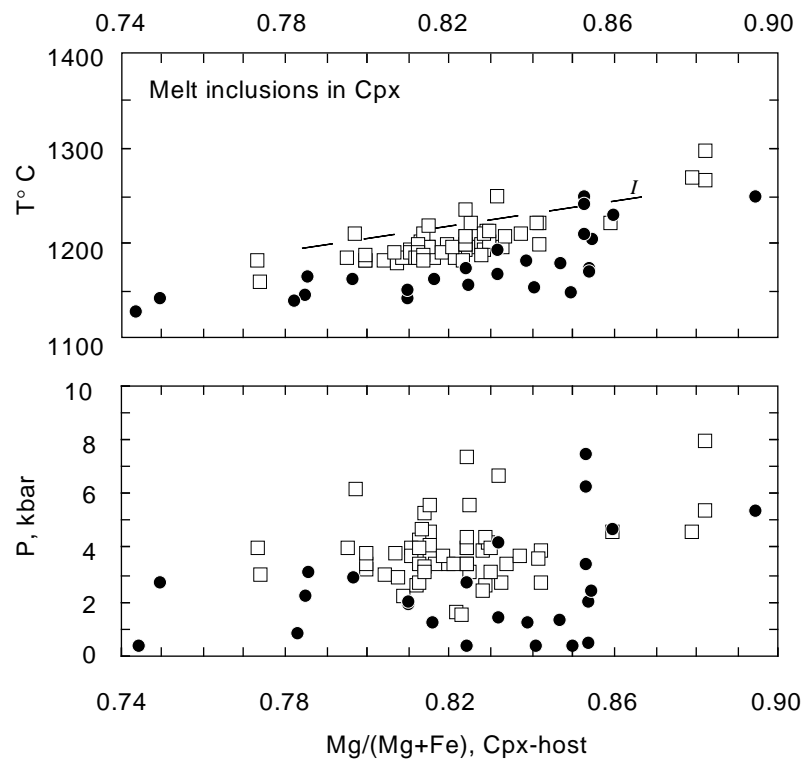

Figure 12. Temperature and pressure of magma crystallization vs. olivine and clinopyroxene composition (see text for explanations). A. Temperature of olivine crystallization. B. Temperature and pressure of clinopyroxene crystallization. Reference lines: $I=$ Miocene shield basalts of Gran Canaria (Gurenko et al., 1996); $I I$ = Mauna Loa shield tholeiites, Hawaii (Sobolev and Nikogosian, 1994); $I I I$ and $I V=$ MORBs from FAMOUS area $(I I I)$ (Kamenetsky et al., 1995) and Vema fracture zone (IV; Sobolev et al. 1989). For legend see Figure 5.

ditions as observed for the late-stage crystallization of Gran Canaria shield stage magmas (Gurenko et al., 1996).

\section{Composition of Fluid Coexisting with Magma}

The presence of $\mathrm{CO}_{2}$-rich fluid inclusions indicates that the parental magmas were fluid-saturated at the depth of phenocryst crystallization. To estimate the concentrations of carbon dioxide in the parental magmas, we used the $\mathrm{CO}_{2}$ dissolution models of Spera and Bergman (1980) and Spera (1984) taking into account that all analyzed fluid inclusions contain nearly pure $\mathrm{CO}_{2}$ (triple point $-56.6 \pm 0.2^{\circ} \mathrm{C}$ ). Because of the very low solubility of $\mathrm{CO}_{2}$ in silicate melts, ascent of the basaltic magma from greater to lower depths result in exsolution of a $\mathrm{CO}_{2}$-rich vapor phase (occurring as fluid inclusions in phenocrysts) and consequent decrease of the $\mathrm{CO}_{2}$ dissolved in the melt. Our estimates are therefore totally dependent on the pressure, and should be regarded as preliminary. 

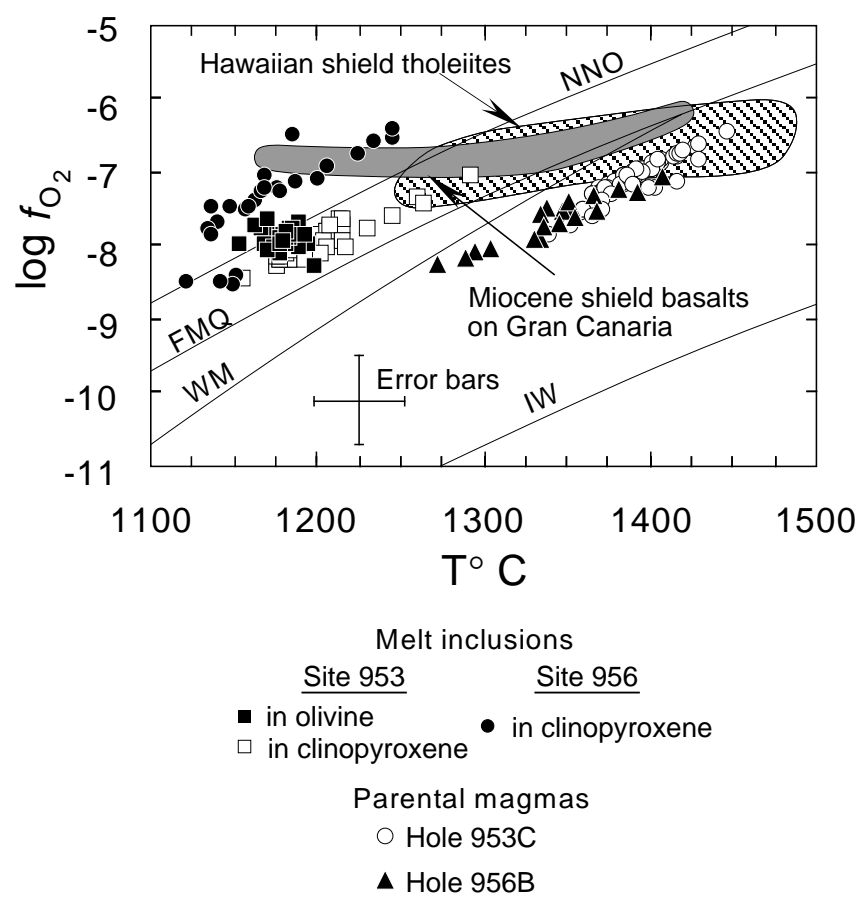

Figure 13. Redox conditions during crystallization of parental magmas. Crystallization of parental magmas occurred at similar redox conditions from FMQ-1 to WM-1 buffers and were close to those obtained for the Miocene shield basalts of Gran Canaria (Gurenko et al., 1996) and Mauna Loa shield tholeiites, Hawaii (Sobolev and Nikogosian, 1994). Late-stage crystallization of parental magmas was accompanied by progressive oxidation up to the conditions corresponding to the FMQ-NNO buffers.

The $\mathrm{CO}_{2}$ concentrations were found to be $0.07-0.20 \mathrm{wt} \%$ for the highest pressure of $3 \mathrm{kbar}$ obtained from the fluid inclusion densities and temperature range of $1100^{\circ}-1400^{\circ} \mathrm{C}$ that is very close to the $\mathrm{CO}_{2}$ concentrations obtained for the Miocene shield basalts of Gran Canaria (0.1-0.3 wt.\% $\mathrm{CO}_{2}$; Gurenko et al., 1996).

\section{CONCLUSIONS}

Detailed mineralogical and geochemical analyses of melt, crystal, and fluid inclusions in olivine and clinopyroxene phenocrysts from the most primitive volcaniclastic rocks drilled during Leg 157 (Sites 953 and 956) allowed us to characterize (1) the composition of magma during the crystallization of olivine and clinopyroxene phenocrysts; (2) pressure, temperature and redox conditions of magma crystallization, and (3) the composition of fluid coexisted with magma; and (4) to discuss the composition and crystallization conditions $\left(\mathrm{T}, \mathrm{P}\right.$, and $\mathrm{f}_{2}$ ).

1. Calculated parental magmas equilibrated with $\mathrm{Fo}_{90}$, and their more evolved derivatives present as inclusions in phenocrysts, represent a spectrum from transitional to quartz-normative tholeiitic compositions (46.7-54.4 wt\% $\mathrm{SiO}_{2}$ ) and are enriched in incompatible trace and rare earth elements. Parental magmas are high magnesian, similar to olivine basalts-picrites (11.2-18.0 wt\% $\mathrm{MgO}$ ), whereas their derivatives are basalts with 5.1-10.7 wt.\% MgO. Trace element concentrations measured directly in melt inclusions by ion microprobe show an enrichment of magmas in LREE $\left[(\mathrm{La} / \mathrm{Sm})_{\mathrm{n}}=1.7-3.0\right]$ and strong depletion in HREE $\left[(\mathrm{Sm} / \mathrm{Yb})_{\mathrm{n}}=4.4-10.2\right]$. This discrepancy in $(\mathrm{La} / \mathrm{Sm})_{\mathrm{n}}$ and $(\mathrm{Sm} / \mathrm{Yb})_{\mathrm{n}}$ together with an elevated
$(\mathrm{Zr} / \mathrm{Y})_{\mathrm{n}}$ ratio of 4.1-5.5 argues for the presence of garnet in the mantle source of the Miocene picritic and basaltic magmas.

2. Crystallization of primary magmas is believed to have occurred over the range of $1490^{\circ}-1150^{\circ} \mathrm{C}$ at pressures from $<0.5$ to 8 kbar producing olivine of $\mathrm{FO}_{78-89}$, high-Ti chrome spinel (2.5$18.7 \mathrm{wt} \% \mathrm{TiO}_{2}$ ) with $\mathrm{Cr} \#$ ranging from 0.17 to 0.74 and $\mathrm{Mg} \#_{\text {sp }}$ from 0.21 to 0.58 , and clinopyroxene of $\mathrm{Mg} \#_{\mathrm{cpx}}=0.74-0.90$ and $\mathrm{Wo}_{37-47}, \mathrm{En}_{41-52}, \mathrm{Fs}_{6-15}$. The redox conditions varied from the conditions corresponding to FMQ-1-WM-1 during the early crystallization stage, to late-stage crystallization conditions of FMQ - NNO+1.

3. Crystallization of magma occurred in the presence of fluid of essentially $\mathrm{CO}_{2}$ composition. Calculated concentrations of carbon dioxide in the primary magmas are between 0.07 and $0.20 \mathrm{wt} \% \mathrm{CO}_{2}$.

\section{ACKNOWLEDGMENTS}

We thank J. Freitag and P. Glöer for technical assistance with electron microprobe analysis of minerals and glasses, M. Chaussidon and D. Mangin for their help and technical assistance with ion microprobe analysis of trace elements and $\mathrm{H}_{2} \mathrm{O}$ in melt inclusions, and $\mathrm{L}$. V. Danyushevsky for providing us with the program PETROLOG. Constructive criticisms of J.D. Webster and an anonymous reviewer significantly improved this paper and are gratefully acknowledged. This work was supported by the Alexander von Humboldt research fellowship to AAG, by grants from Deutsche Forschungsgemeinschaft Ha 2100/2-1 to THH, and Schm 250/40-1 and 60-2 to HUS.

\section{REFERENCES}

Anders, E., and Grevesse, N., 1989. Abundances of the elements: meteoritic and solar. Geochim. Cosmochim. Acta, 53:197-214.

Angus, S., Armstrong, B., and de Reuck, K.M., 1976. International Thermodynamic Tables of the Fluid State, Carbon Dioxide: New York (Pergamon Press).

Arai, S., 1987. An estimation of the least depleted spinel peridotite on the basis of olivine-spinel mantle array. Neues Jahrb. Mineral. Monatsh., 8:347-354.

Ariskin, A.A., 1985. Dynamics of the partition of chemical elements at crystallization of mafic and ultramafic magmas [Ph.D. dissert.]. GEOKhI, Moscow. (in Russian)

Ariskin, A.A., Barmina, G.S., and Frenkel, M.Y., 1987. Computer simulation of basalt magma crystallization at a fixed oxygen fugacity. Geochem. Int., 24:85-98.

Ariskin, A.A., Frenkel, M.Y., Barmina, G.S., and Nielsen, R., 1993. COMAGMAT: A FORTRAN program to model magma differentiation processes. Comput. Geosci., 19:1155-1170.

Bender, J.F., Hodges, F.N., and Bence, A.E., 1978. Petrogenesis of basalts from the Project FAMOUS area: experimental study from 0 to 15 kbars. Earth Planet. Sci. Lett., 41:277-302.

Borisov, A.A., and Shapkin, A.I., 1990. A new empirical equation rating $\mathrm{Fe}^{3+} / \mathrm{Fe}^{2+}$ in magmas to their composition, oxygen fugacity, and temperature. Geochem. Int., 27:111-116.

Brown, P.E., 1989. FLINCOR: a fluid inclusion data reduction and exploration program. Second Biennial Pan-American Conf. on Research on Fluid Inclusions, Prog. with Abstr., 14. (Abstract)

Byers, C.D., Garcia, M.O., and Muenow, D.W., 1985. Volatiles in pillow rim glasses from Loihi and Kilauea volcanoes, Hawaii. Geochim. Cosmochim. Acta, 49:1887-1896.

Clague, D.A., Moore, J.G., Dixon, J.E., and Friesen, W.B., 1995. Petrology of submarine lavas from Kilauea's Puna Ridge, Hawaii. J. Petrol., 36:299-349.

Dalton, J.A., and Lane, S.J., 1996. Electron microprobe analysis of Ca in olivine close to grain boundaries: the problem of secondary X-ray fluorescence. Am. Mineral., 81:194-201.

Deloule, E., France-Lanord, C., and Albarède, F., 1991. D/H analysis of minerals by ion probe. In Taylor, H.P., O'Neil, J.R., and Kaplan, I.R. (Eds.), Stable Isotope Geochemistry: A Tribute to Samuel Epstein. Geochem. Soc., 53-62. 
Dick, H.J.B., and Bullen, T., 1984. Chromian spinel as a petrogenetic indicator in abyssal and alpine-type peridotites and spatially associated lavas. Contrib. Mineral. Petrol., 86:54-76.

Eggins, S.M., 1992. Petrogenesis of Hawaiian tholeiites: 1. Phase equilibria constraints. Contrib. Mineral. Petrol., 110:387-397.

Fahey, A.J., Goswami, J.N., McKeegan, K.D., and Zinner, E., 1987. ${ }^{26} \mathrm{Al}$, ${ }^{244} \mathrm{Pu},{ }^{50} \mathrm{Ti}$, REE, and trace element abundances in hibonite grains from $\mathrm{CM}$ and CV meteorites. Geochim. Cosmochim. Acta, 51:329-350.

Falloon, T.J., and Green, D.H., 1988. Anhydrous partial melting of peridotite from 8 to $35 \mathrm{~kb}$ and the petrogenesis of MORB. J. Petrol., Spec. Lithosphere Iss., 379-414.

Ford, C.E., Russell, D.G., Craven, J.A., and Fisk, M.R. 1983. Olivine-liquid equilibria: temperature, pressure and compositional dependence of the crystal/liquid cation partition coefficients for $\mathrm{Mg}, \mathrm{Fe} 2+, \mathrm{Ca}$, and $\mathrm{Mn} . J$. Petrol., 24:256-265.

Funck, T., 1996. Structure of the volcanic apron north of Gran Canaria deduced from reflection seismic, bathymetric and borehole data [Ph.D. dissert.]. Univ. Kiel.

Garcia, M.O., Hulsebosch, T.P., and Rhodes, J.M., 1995. Olivine-rich submarine basalts from southwest rift zone of Mauna Loa volcano: implications for magmatic processes and geochemical evolution. In Rhodes, J.M., and Lockwood, J.P. (Eds.), Mauna Loa Revealed: Structure, Composition, History, and Hazards. Am. Geophys. Union, Geophys. Monogr., 92:219239.

Garcia, M.O., Muenow, D.W., Aggrey, K.E., and O’Neil, J.R., 1989. Major element, volatile, and stable isotope geochemistry of Hawaiian submarine tholeiitic glasses. J. Geophys. Res., 94:10525-10538.

Green, D.H., Sie, S.H., Ryan, C.G., and Cousens, D.R., 1989. Proton microprobe-determined partitioning of $\mathrm{Nb}, \mathrm{Ta}, \mathrm{Zr}, \mathrm{Sr}$ and $\mathrm{Y}$ between garnet, clinopyroxene and basaltic magma at high pressure and temperature. Chem. Geol., 74:201-216.

Gurenko, A.A., and Chaussidon, M., 1995. Enriched and depleted primitive melts included in olivine from Icelandic tholeiites: origin by continuous melting of a single mantle column. Geochim. Cosmochim. Acta, 59:2905-2917

Gurenko, A.A., Hansteen, T.H., and Schmincke H.-U., 1996. Evolution of parental magmas of Miocene shield basalts of Gran Canaria (Canary Islands): constraints from crystal, melt and fluid inclusions in minerals. Contrib. Mineral. Petrol., 124:422-435.

Hervig, R.L., Smith, J.V., and Dawson, J.B., 1986. Lherzolite xenoliths in kimberlites and basalts: petrogenetic and crystallochemical significance of some minor and trace elements in olivine, pyroxene, garnet and spinel. Trans. R. Soc. Edinburgh, Earth. Sci., 77:181-201.

Hinton, R.W., 1990. Ion microprobe trace-element analysis of silicates: measurement of multi-element glasses. Chem. Geol., 83:11-25.

Hirose, K., and Kushiro, I., 1993. Partial melting of dry peridotites at high pressures: determination of compositions of melts segregated from peridotite using aggregates of diamond. Earth Planet. Sci. Lett., 114:477489.

Hoernle, K., and Schmincke, H.-U., 1993a. The petrology of the tholeiites through melilite nephelinites on Gran Canaria, Canary Islands: crystal fractionation, accumulation, and depth of melting. J. Petrol., 34:573-578.

, 1993b. The role of partial melting in the 15-Ma geochemical evolution of Gran Canaria: a blob model for the Canary Hotspot. J. Petrol., 34:599-627.

Jambon, A., and Zimmermann, J.L., 1990. Water in oceanic basalts: evidence for dehydration of recycled crust. Earth Planet. Sci. Lett., 101:323-331.

Jaques, A.L., and Green, D.H., 1980. Anhydrous melting of peridotite at 0$15 \mathrm{~kb}$ pressure and the genesis of the tholeiitic basalts. Contrib. Mineral. Petrol., 73:287-310.

Jarosewich, E., Nelen, J.A., and Norberg, J.A., 1980. Reference samples for electron microprobe analysis. Geostand. Newsl., 4:43-47.

Jenner, G.A., Foley, S.F., Jackson, S.E., Green, H., Fryer, B.J., and Longerich, H.P., 1994. Determination of partition coefficients for trace elements in high pressure-temperature experimental run products by laser ablation microprobe-inductively coupled plasma-mass spectrometry (LAM-ICPMS). Geochim. Cosmochim. Acta, 58:5099-5103.

Kamenetsky, V.S., Métrich, N., and Cioni, R., 1995. Potassic primary melts of Vulsini (Roman Province): evidence from mineralogy and melt inclusions. Contrib. Mineral. Petrol., 120:186-196.

Kelemen, P.B., Shimizu, N., and Dunn, T., 1993. Relative depletion of niobium in some arc magmas and the continental crust: partitioning of $\mathrm{K}$, $\mathrm{Nb}, \mathrm{La}$, and $\mathrm{Ce}$ during melt/rock reaction in the upper mantle. Earth Planet. Sci. Lett., 120:111-133.
Kerrick, D.M., and Jacobs, G.K., 1981. A remodified Redlich-Kwong equation for $\mathrm{H}_{2} \mathrm{O}-\mathrm{CO}_{2}$ and $\mathrm{H}_{2} \mathrm{O}-\mathrm{CO} 2-\mathrm{NaCl}$ mixtures at elevated pressures and temperatures. Am. J. Sci., 281:735-767.

Kilinc, A., Carmichael, I.S.E., Rivers, M.L., and Sack, R.O., 1983. The ferric-ferrous ratio of natural silicate liquids equilibrated in air. Contrib. Mineral. Petrol., 83:136-140.

Kinzler, R.J., and Grove, T.L., 1993. Corrections and further discussion of the primary magmas of mid-ocean ridge basalts, 1 and 2. J. Geophys. Res., 98:22339-22347.

Langmuir, C.H., Bender, J.F., Bence, A.E., and Hanson, G.N., 1977. Petrogenesis of basalts from the FAMOUS area: Mid-Atlantic Ridge. Earth Planet. Sci. Lett., 36:133-156.

Lavrentev, Y.G., Pospelova, L.N., and Sobolev, A.V., 1974. Rock-forming mineral compositions determination by X-ray microanalysis. Zavodsk. Lab., 40:657-666. (in Russian)

Macdonald, G.A., and Katsura, T., 1964. Chemical composition of Hawaiian lavas. J. Petrol., 5:82-133.

Maurel, C., and Maurel, P., 1982. Etude expérimentale de l'équilibre $\mathrm{Fe}^{2+}$ $\mathrm{Fe}^{3+}$ dans les spinelles chromifères et les liquides silicatés basiques coexistants, à $1 \mathrm{~atm}$. C.R. Acad. Sci. Paris, 285:209-215.

Michael, P., 1995. Regionally distinctive source of depleted MORB: evidence for trace elements and $\mathrm{H}_{2} \mathrm{O}$. Earth Planet. Sci. Lett., 131:301-320.

Moore, J.G., 1970. Water content of basalt erupted on the ocean floor. Contrib. Mineral. Petrol., 28:272-279.

Muenow, D.W., Garcia, M.O., Aggrey, K.E., Bednarz, U., and Schmincke, H.-U., 1990. Volatiles in submarine glasses as a discriminant of tectonic origin: application to the Troodos ophiolite. Nature, 343:159-161.

Nathan, H.D., and Van Kirk, C.K., 1978. A model of magmatic crystallization. J. Petrol., 19:66-94.

Neumann, E.-R., 1991. Ultramafic and mafic xenoliths from Hierro, Canary Islands: evidence for melt infiltration in the upper mantle. Contrib. Mineral. Petrol., 106:236-252.

Neumann, E.-R., Wulff-Pedersen, E., Johnsen, K., Andersen, T., and Krogh, E., 1995. Petrogenesis of spinel harzburgite and dunite suite xenoliths from Lanzarote, eastern Canary Islands: implications for the upper mantle. Lithos, 35:83-107.

Nielsen, R.L., and Drake, M.J., 1979. Pyroxene-melt equilibria. Geochim. Cosmochim. Acta, 43:1259-1272.

Nisbet, E.G., 1982. The tectonic setting and petrogenesis of komatiite. In Arndt, N.T., and Nisbet, E.G. (Eds.), Komatiites: London (George Allen and Unwin), 501-520.

Pichavant, M., Herrera, J.V., Boulmier, S., Briqueu, L., Joron, J.-L., Juteau, M., Marin, L., Michard, A., Sheppard, S.M.F., Treuil, M., and Vernet, M., 1987. The Macusani glasses, SE Peru: evidence of chemical fractionation in peraluminous magmas. In Mysen, B.O. (Ed.), Magmatic Processes: Physicochemical Principles. Geochem. Soc., Spec. Publ., 1:359-373.

Rautenschlien, M., Jenner, G.A., Hertogen, J., Hoffmann, A.W., Kerrich, R., Schmincke, H.U., and White, W.M., 1985. Isotopic and trace element composition of volcanic glasses from Akaki Canyon, Cyprus: implications for the origin of the Troodos ophiolite. Earth Planet. Sci. Lett., 75:369-383.

Rhodes, J.M., and Hart, S.R., 1995. Episodic trace element and isotopic variations in Historical Mauna Loa lavas: Implications for magma and plume dynamics. In Rhodes, J.M., and Lockwood, J.P. (Eds.), Mauna Loa Revealed: Structure, Composition, History, and Hazards. Am. Geophys. Union, Geophys. Monogr., 92:263-288.

Roedder, E., 1984. Fluid inclusions. Rev. Mineral., Mineral. Soc. Am., 12.

Roeder, P.L., and Emslie, R.F., 1970. Olivine-liquid equilibrium. Contrib. Mineral. Petrol., 29:275-289.

Sack, R.O., Carmichael, I.S.E., Rivers, M.L., and Ghiorso, M.S., 1980. Ferric-ferrous equilibria in natural silicate liquids at 1 bar. Contrib. Mineral. Petrol., 75:369-376.

Schmincke, H.-U., 1982. Volcanic and chemical evolution of the Canary Islands. In von Rad, U., Hinz, K., Sarnthein, M., and Seibold, E. (Eds.), Geology of the Northwest African Continental Margin: Berlin (Springer), 273-306.

Schmincke, H.-U., and Flower, J.F., 1974. Magmenevolution auf atlantischen Vulkaninseln. Naturwissenschaften, 61:288-297.

Schmincke, H.-U., Weaver, P.P.E., and Firth, J., 1995a. The clastic apron of Gran Canaria and the Madeira Abyssal Plain. JOIDES J., 21:14-22.

Schmincke, H.-U., Weaver, P.P.E., Firth, J.V., et al., 1995b. Proc. ODP, Init. Repts., 157: College Station, TX (Ocean Drilling Program).

Shipboard Scientific Party, 1995a. Site 953. In Schmincke, H.-U., Weaver, P.P.E., Firth, J.V., et al., Proc. ODP, Init. Repts., 157: College Station, TX (Ocean Drilling Program), 317-394. 
Shipboard Scientific Party, 1995b. Site 956. In Schmincke, H.-U., Weaver, P.P.E., Firth, J.V., et al., Proc. ODP, Init. Repts., 157: College Station, TX (Ocean Drilling Program), 497-557.

Sobolev, A.V., and Chaussidon, M., 1996. $\mathrm{H}_{2} \mathrm{O}$ concentrations in primary melts from supra-subduction zones and mid-ocean ridges: Implications for $\mathrm{H}_{2} \mathrm{O}$ storage and recycling in the mantle. Earth Planet. Sci. Lett., 137:45-55.

Sobolev, A.V., Danyushevsky, L.V., Dimitriyev, L.V., and Sushevskaya, N.M., 1989. High-alumina magnesian tholeiite as the primary basalt magma at midocean ridge. Geochem. Int., 26:128-133.

Sobolev, A.V., and Nikogosian, I.K., 1994. Petrology of long-lived mantle plume magmatism: Hawaii, Pacific, and Reunion Island, Indian Ocean. Petrology, 2:111-144.

Sobolev, A.V., Portnyagin, M.V., Dmitriev, L.V., Tsameryan, O.P., Danyushevsky, L.V., Kononkova, N.N., Shimizu, N., and Robinson, P.T., 1993. Petrology of ultramafic lavas and associated rocks of the Troodos Massif, Cyprus. Petrology, 1:331-361.

Spera, F.G., 1984. Carbon dioxide in igneous petrogenesis, III: role of volatiles in the ascent of alkaline magma with special reference to xenolithbearing mafic lavas. Contrib. Mineral. Petrol., 88:217-232.
Spera, F.G., and Bergman, S.C., 1980. Carbon dioxide in igneous petrogenesis, I: aspects of the dissolution of $\mathrm{CO}_{2}$ in silicate liquids. Contrib. Mineral. Petrol., 74:54-66.

Stolper, E., 1980. A phase diagram for mid-ocean ridge basalts: preliminary results and implications for petrogenesis. Contrib. Mineral. Petrol., 78:13-27.

Takahashi, E., and Kushiro, I., 1983. Melting of a dry peridotite at high pressures and temperatures and basalt magma genesis. Am. Mineral., 68:859879.

Wyllie, P.J., 1988. Solidus curves, mantle plumes, and magma generation beneath Hawaii. J. Geophys. Res., 93:4171-4181.

Date of initial receipt: 8 July 1996

Date of acceptance: 24 January 1997

Ms 157SR-111

Appendix Table 1. Compositions of spinel inclusions and their host olivines and clinopyroxenes.

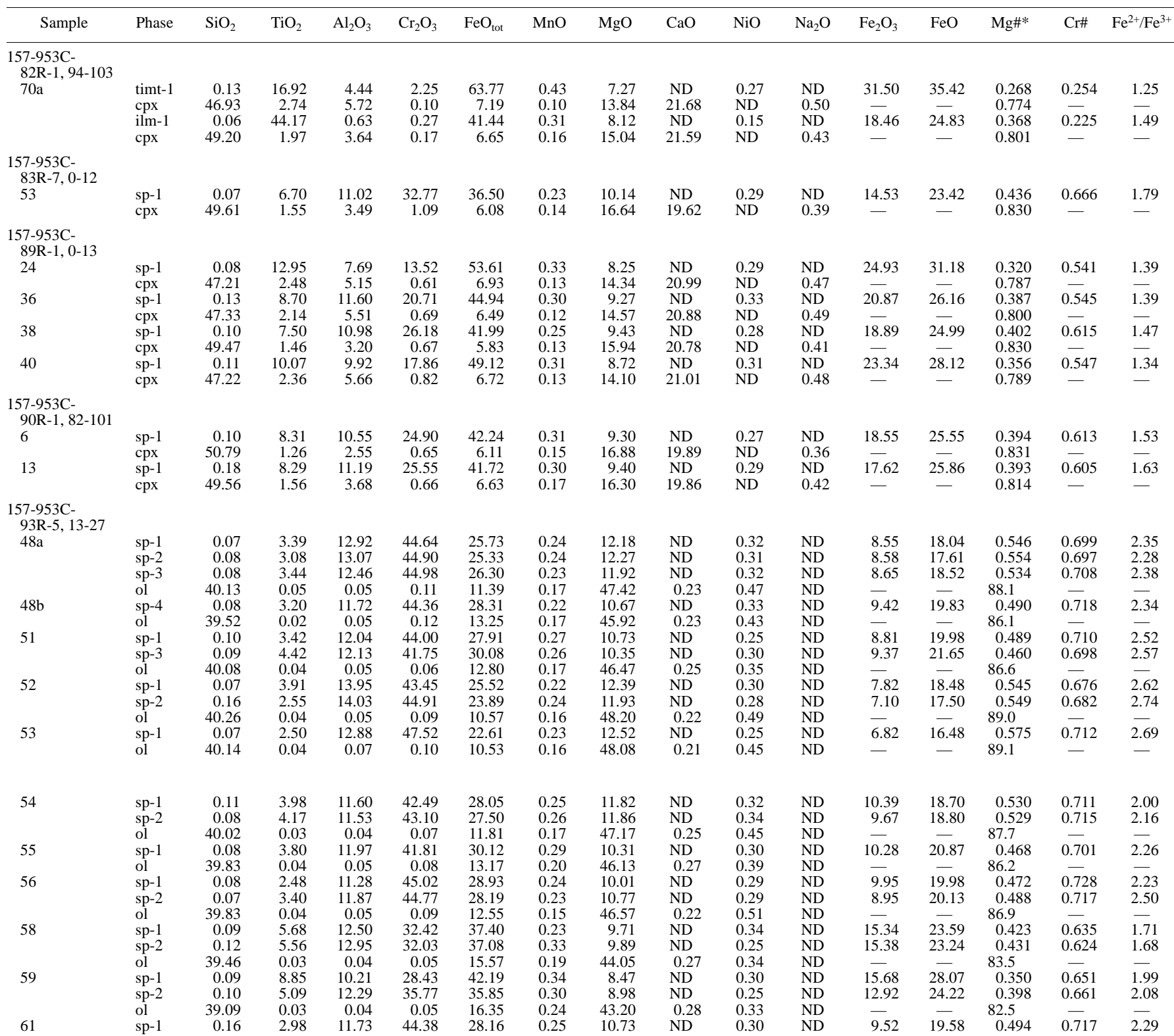


Appendix Table 1 (continued).

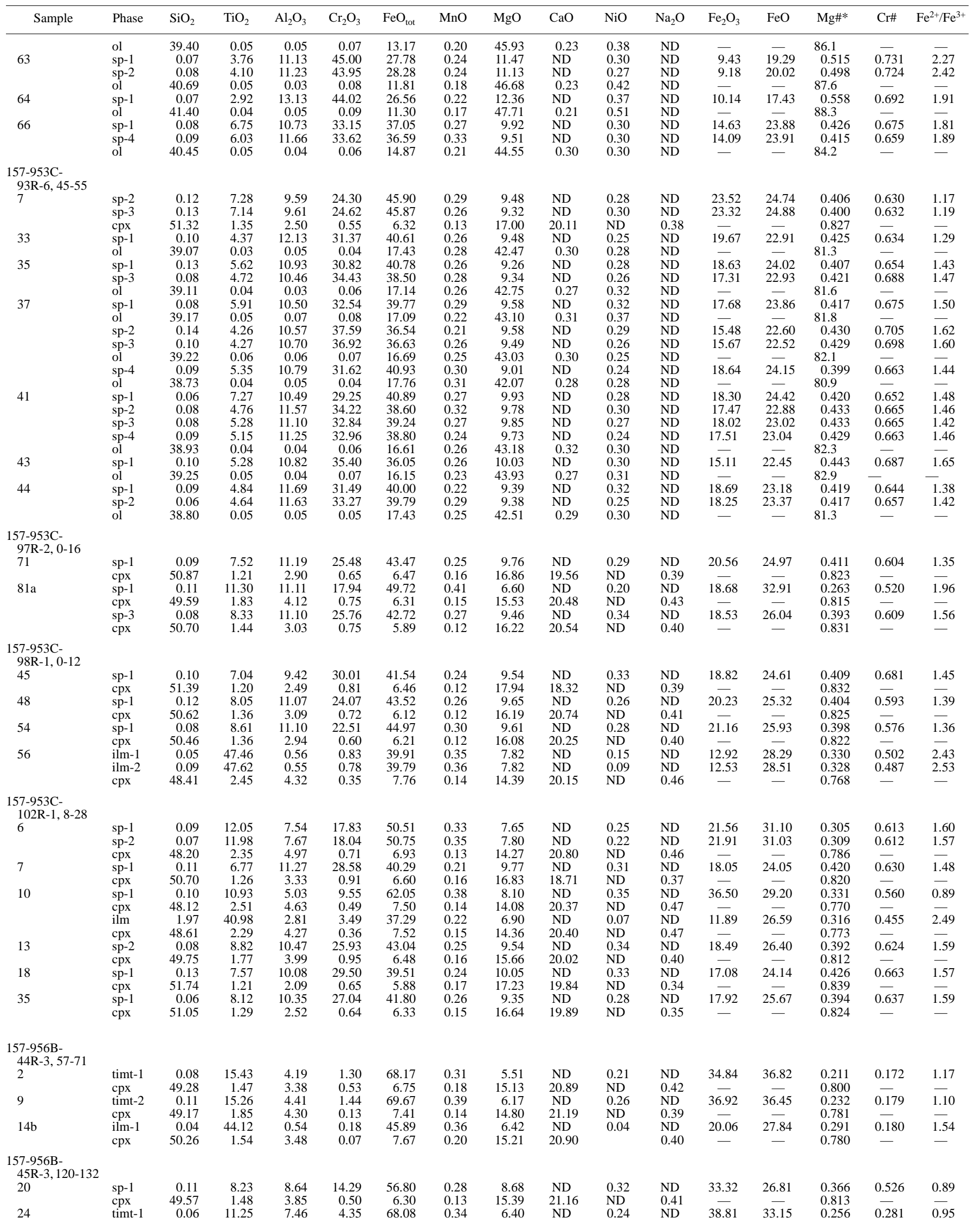


Appendix Table 1 (continued).

\begin{tabular}{|c|c|c|c|c|c|c|c|c|c|c|c|c|c|c|c|c|}
\hline Sample & Phase & $\mathrm{SiO}_{2}$ & $\mathrm{TiO}_{2}$ & $\mathrm{Al}_{2} \mathrm{O}_{3}$ & $\mathrm{Cr}_{2} \mathrm{O}_{3}$ & $\mathrm{FeO}_{\text {tot }}$ & $\mathrm{MnO}$ & $\mathrm{MgO}$ & $\mathrm{CaO}$ & $\mathrm{NiO}$ & $\mathrm{Na}_{2} \mathrm{O}$ & $\mathrm{Fe}_{2} \mathrm{O}_{3}$ & $\mathrm{FeO}$ & Mg\#* & $\mathrm{Cr} \#$ & $\mathrm{Fe}^{2+} / \mathrm{Fe}^{3+}$ \\
\hline \multirow{5}{*}{33} & cpx & 49.35 & 1.67 & 4.21 & 0.40 & 6.95 & 0.15 & 14.91 & 21.18 & ND & 0.39 & - & - & 0.793 & - & - \\
\hline & sp-1 & 0.48 & 9.70 & 7.85 & 10.34 & 60.41 & 0.30 & 8.22 & ND & 0.24 & ND & 34.52 & 29.34 & 0.333 & 0.469 & 0.94 \\
\hline & & 49.52 & 1.58 & 4.27 & 0.44 & 6.37 & 0.12 & 15.09 & 21.62 & ND & 0.37 & & & 0.809 & & \\
\hline & $\mathrm{sp}-2$ & 0.10 & 7.92 & 8.37 & 15.19 & 56.64 & 0.33 & 8.78 & ND & 0.33 & ND & 33.63 & 26.37 & 0.372 & 0.549 & 0.87 \\
\hline & cpx & 50.40 & 1.36 & 3.46 & 0.53 & 5.97 & 0.12 & 15.71 & 21.87 & ND & 0.34 & - & - & 0.824 & - & - \\
\hline \multirow[t]{2}{*}{39} & $\mathrm{sp}-1$ & 0.13 & 12.33 & 5.91 & 8.87 & 62.57 & 0.32 & 7.33 & ND & 0.23 & ND & 33.62 & 32.32 & 0.288 & 0.502 & 1.07 \\
\hline & cpx & 50.57 & 1.48 & 3.32 & 0.22 & 6.76 & 0.14 & 15.53 & 21.57 & ND & 0.34 & - & & 0.804 & - & 1.01 \\
\hline \multirow[t]{2}{*}{51} & sp-1 & 0.13 & 14.74 & 5.90 & 5.59 & 63.35 & 0.31 & 7.52 & ND & 0.26 & ND & 32.38 & 34.21 & 0.282 & 0.389 & 1.17 \\
\hline & & 49.57 & 1.78 & 4.15 & 0.34 & 6.69 & 0.12 & 15.15 & 21.40 & ND & 0.38 & $\overline{-1}$ & & 0.801 & - & - \\
\hline \multirow[t]{2}{*}{52} & sp-1 & 0.06 & 8.86 & 8.06 & 18.07 & 52.63 & 0.24 & 7.76 & ND & 0.24 & ND & 27.14 & 28.21 & 0.329 & 0.601 & 1.15 \\
\hline & cpx & 49.45 & 1.39 & 3.47 & 0.49 & 5.82 & 0.13 & 15.28 & 21.35 & ND & 0.44 & - & - & 0.824 & - & - \\
\hline \multicolumn{17}{|c|}{$\begin{array}{l}\text { 157-956B- } \\
\text { 45R-CC, 51-71 }\end{array}$} \\
\hline \multirow{2}{*}{57} & sp-1 & 0.10 & 10.32 & 6.51 & 11.06 & 59.66 & 0.31 & 7.30 & ND & 0.24 & ND & 33.06 & 29.91 & 0.303 & 0.532 & 1.01 \\
\hline & cpx & 49.23 & 1.52 & & 0.4 & 6.8 & 0.14 & 15.12 & 20.61 & ND & 0.50 & 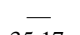 & 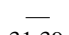 & 0.7 & - & - \\
\hline \multirow[t]{2}{*}{72} & $\mathrm{sp}-1$ & 0.24 & 12.06 & & 7.26 & 63.0 & 0.34 & 7.72 & ND & 0.32 & ND & 35.17 & 31.39 & 0.305 & 0.443 & 0.99 \\
\hline & cpx & 49.51 & 1.84 & 4.25 & 0.31 & 6.96 & 0.14 & 15.05 & 21.31 & ND & 0.38 & - & - & 0.794 & - & - \\
\hline \multirow[t]{2}{*}{73} & timt-1 & 0.15 & 18.69 & 4.27 & 1.53 & 66.08 & 0.35 & 6.21 & ND & 0.18 & ND & 29.63 & 39.41 & 0.219 & 0.194 & 1.48 \\
\hline & & 50.55 & 1.72 & 3.00 & 0.09 & 7.88 & 0.15 & 15.14 & 20.67 & ND & 0.39 & - & 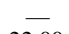 & 0.774 & - & .1. \\
\hline \multirow[t]{2}{*}{74} & sp-1 & 0.09 & 3.99 & 8.24 & 35.81 & 40.16 & 0.30 & 9.35 & ND & 0.21 & ND & 20.17 & 22.00 & 0.431 & 0.744 & 1.21 \\
\hline & cpx & 52.47 & 0.75 & 1.85 & 0.79 & 5.00 & 0.11 & 16.93 & 21.76 & ND & 0.30 & - & - & 0.858 & - & - \\
\hline
\end{tabular}

Notes: Sample $=$ sample studied (core, section, interval $[\mathrm{cm}]$, and analyzed grain). $\mathrm{FeO}_{\text {tot }}=$ measured with electron microprobe. $\mathrm{Fe} \mathrm{O}_{3}$ and $\mathrm{FeO}$ are calculated on the basis of stoichiometry, for spinel and Ti-magnetite from general spinel formula $\left(\mathrm{A}^{2+}\right)\left(\mathrm{B}^{3+}\right)_{2} \mathrm{O}_{4}$, taking in to account the presence of Ti as ulvöspinel component $\left(\mathrm{Fe}^{2+}\right)_{2}\left(\mathrm{Ti}^{4+}\right) \mathrm{O}_{4}$, and for ilmenite from formula $\mathrm{Fe}^{2+} \mathrm{TiO}_{3}$ assuming the presence of $\mathrm{Fe}_{2} \mathrm{O}_{3}$ component. $*$ = for spinel and titanomagnetite $\mathrm{Mg} \#$ is atomic ratio $\mathrm{Mg} /\left(\mathrm{Mg}+\mathrm{Fe}{ }^{2+}\right)$, for olivine, mol\% Fo, for clinopyroxene -atomic ratio $\mathrm{Mg} /\left(\mathrm{Mg}+\mathrm{Fe}_{\text {tot }}\right)$, and $\mathrm{Cr} \#=$ atomic ratio $\mathrm{Cr} /(\mathrm{Cr}+\mathrm{Al})$. Inclusions include: $\mathrm{sp}=$ spinel, $\mathrm{mt}=$ titanomagnetite, and ilm = ilmenite. Host minerals include: ol = olivine and $\mathrm{cpx}=$ clinopyroxene. $-=$ not calculated, and $\mathrm{ND}=$ not determined.

Appendix Table 2. Analyses of olivine, clinopyroxene and plagioclase inclusions, and their host minerals.

\begin{tabular}{|c|c|c|c|c|c|c|c|c|c|c|c|c|c|}
\hline Sample & Phase & $\mathrm{SiO}_{2}$ & $\mathrm{TiO}_{2}$ & $\mathrm{Al}_{2} \mathrm{O}_{3}$ & $\mathrm{Cr}_{2} \mathrm{O}_{3}$ & $\mathrm{FeO}_{\text {tot }}$ & $\mathrm{MnO}$ & $\mathrm{MgO}$ & $\mathrm{CaO}$ & $\mathrm{NiO}$ & $\mathrm{Na}_{2} \mathrm{O}$ & $\mathrm{K}_{2} \mathrm{O}$ & $\mathrm{Mg \# ,An}$ \\
\hline \multicolumn{14}{|l|}{$157-953 C-$} \\
\hline $\begin{array}{l}82 \mathrm{R}-1,52-82 \\
60\end{array}$ & $\begin{array}{l}\text { ol-incl } \\
\text { cpx-host }\end{array}$ & $\begin{array}{l}37.94 \\
49.30\end{array}$ & $\begin{array}{l}0.06 \\
1.95\end{array}$ & $\begin{array}{l}0.04 \\
3.67\end{array}$ & $\begin{array}{l}0.05 \\
0.32\end{array}$ & $\begin{array}{r}18.66 \\
6.57\end{array}$ & $\begin{array}{l}0.26 \\
0.13\end{array}$ & $\begin{array}{l}40.54 \\
14.86\end{array}$ & $\begin{array}{r}0.46 \\
21.35\end{array}$ & $\begin{array}{l}0.21 \\
0.03\end{array}$ & $\begin{array}{l}\text { ND } \\
0.45\end{array}$ & $\begin{array}{l}\text { ND } \\
\text { ND }\end{array}$ & $\begin{array}{l}79.5 \\
0.801\end{array}$ \\
\hline \multicolumn{14}{|l|}{$157-953 \mathrm{C}-$} \\
\hline & ol-incl & 39.26 & 0.08 & 0.05 & 0.04 & 19.63 & 0.36 & 39.80 & 0.46 & 0.29 & ND & ND & 78.3 \\
\hline & cpx-host & 49.20 & 1.97 & 3.64 & 0.17 & 6.65 & 0.16 & 15.04 & 21.59 & 0.03 & 0.43 & ND & 0.801 \\
\hline \multicolumn{14}{|l|}{ 157-953C- } \\
\hline \multirow[t]{2}{*}{$\begin{array}{l}83 \mathrm{R}-7,0-12 \\
43\end{array}$} & ol-incl & 37.70 & 0.09 & 0.07 & 0.05 & 18.91 & 0.29 & 40.20 & 0.47 & 0.24 & ND & ND & 79.1 \\
\hline & cpx-host & 49.46 & 1.66 & 3.26 & 0.38 & 6.67 & 0.15 & 15.49 & 20.76 & 0.06 & 0.44 & ND & 0.805 \\
\hline \multirow[t]{2}{*}{44} & ol-incl & 38.16 & 0.06 & 0.05 & 0.07 & 18.52 & 0.27 & 40.54 & 0.47 & 0.28 & $\mathrm{ND}$ & ND & 79.6 \\
\hline & cpx-host & 49.20 & 1.63 & 3.27 & 0.49 & 6.45 & 0.11 & 16.03 & 20.27 & 0.05 & 0.41 & ND & 0.816 \\
\hline \multirow[t]{3}{*}{50} & ol-incl-1 & 38.40 & 0.05 & 0.05 & 0.05 & 18.44 & 0.26 & 40.98 & 0.40 & 0.27 & ND & ND & 79.8 \\
\hline & ol-incl-2 & 38.27 & 0.04 & 0.05 & 0.05 & 18.36 & 0.29 & 41.08 & 0.35 & 0.28 & ND & ND & 80.0 \\
\hline & cpx-host & 48.64 & 1.88 & 4.80 & 0.79 & 6.59 & 0.11 & 15.07 & 20.04 & 0.09 & 0.49 & ND & 0.803 \\
\hline \multirow[t]{2}{*}{51} & ol-incl & 38.11 & 0.06 & 0.05 & 0.05 & 18.71 & 0.26 & 40.73 & 0.40 & 0.26 & ND & ND & 79.5 \\
\hline & cpx-host & 48.99 & 1.88 & 3.86 & 0.77 & 6.53 & 0.13 & 15.88 & 19.87 & 0.08 & 0.44 & ND & 0.812 \\
\hline \multirow{2}{*}{\multicolumn{14}{|c|}{ 157-953C- }} \\
\hline & & & & & & & & & & & & & $89 \mathrm{R}-1,0-13$ \\
\hline 24 & ol-incl & 38.04 & 0.09 & 0.06 & 0.05 & 17.83 & 0.25 & 41.24 & 0.48 & 0.29 & ND & ND & 80.5 \\
\hline 24 & cpx-host & 49.11 & 1.79 & 3.46 & 0.40 & 6.71 & 0.16 & $\begin{array}{l}15.33 \\
15.24\end{array}$ & 20.95 & 0.06 & 0.45 & ND & 0.803 \\
\hline \multirow[t]{2}{*}{25} & ol-incl & 37.93 & 0.08 & 0.07 & 0.05 & 17.88 & 0.22 & 41.23 & 0.44 & 0.29 & ND & ND & 80.4 \\
\hline & cpx-host & 47.81 & 2.11 & 5.21 & 0.78 & 6.42 & 0.15 & 14.77 & 20.70 & 0.08 & 0.46 & ND & 0.804 \\
\hline \multirow[t]{2}{*}{29} & ol-incl & 37.98 & 0.05 & 0.04 & 0.04 & 18.33 & 0.28 & 40.75 & 0.43 & 0.23 & $\mathrm{ND}$ & ND & 79.9 \\
\hline & cpx-host & 48.93 & 1.57 & 3.44 & 0.62 & 6.12 & 0.12 & 15.40 & 21.11 & 0.06 & 0.42 & ND & 0.818 \\
\hline \multirow[t]{3}{*}{36} & ol-incl-1 & 38.08 & 0.07 & 0.06 & 0.04 & 17.81 & 0.31 & 41.43 & 0.41 & 0.29 & ND & ND & 80.6 \\
\hline & ol-incl-2 & 38.07 & 0.08 & 0.09 & 0.05 & 17.57 & 0.28 & 41.44 & 0.44 & 0.24 & ND & ND & 80.8 \\
\hline & cpx-host & 50.20 & 1.43 & 3.08 & 0.52 & 6.14 & 0.12 & 16.07 & 20.60 & 0.04 & 0.42 & ND & 0.824 \\
\hline \multirow{2}{*}{\multicolumn{14}{|c|}{$\begin{array}{l}157-953 \mathrm{C}- \\
90 \mathrm{R}-1.82-101\end{array}$}} \\
\hline & & & & & & & & & & & & & \\
\hline \multirow[t]{2}{*}{7} & ol-incl & 38.18 & 0.05 & 0.04 & 0.06 & 16.87 & 0.27 & 42.02 & 0.41 & 0.30 & ND & ND & 81.6 \\
\hline & cpx-host & 50.84 & 1.22 & 2.89 & 0.67 & $\begin{array}{r}6.15 \\
1867\end{array}$ & 0.15 & 16.71 & 19.86 & 0.04 & 0.40 & ND & $\begin{array}{r}0.829 \\
706\end{array}$ \\
\hline \multirow[t]{2}{*}{8} & $\begin{array}{l}\text { ol-incl-1 } \\
\text { ol-incl-2 }\end{array}$ & $\begin{array}{l}37.96 \\
38.09\end{array}$ & $\begin{array}{l}0.07 \\
0.09\end{array}$ & $\begin{array}{l}0.06 \\
0.04\end{array}$ & $\begin{array}{l}0.06 \\
0.05\end{array}$ & $\begin{array}{l}18.67 \\
18.42\end{array}$ & $\begin{array}{l}0.27 \\
0.25\end{array}$ & $\begin{array}{l}40.95 \\
40.99\end{array}$ & $\begin{array}{l}0.41 \\
0.41\end{array}$ & $\begin{array}{l}0.27 \\
0.28\end{array}$ & $\begin{array}{l}\text { ND } \\
\text { ND }\end{array}$ & $\begin{array}{l}\text { ND } \\
\text { ND }\end{array}$ & $\begin{array}{l}79.6 \\
79.9\end{array}$ \\
\hline & $\begin{array}{l}\text { ol-incl-2 } \\
\text { cpx-host }\end{array}$ & $\begin{array}{l}58.09 \\
50.93\end{array}$ & 1.41 & 2.75 & 0.54 & $\begin{array}{r}18.42 \\
6.36\end{array}$ & 0.16 & 16.72 & 20.05 & 0.06 & 0.41 & ND & 0.824 \\
\hline \multirow[t]{4}{*}{11} & ol-incl-1 & 38.12 & 0.06 & 0.04 & 0.02 & 18.42 & 0.25 & 41.33 & 0.37 & 0.29 & ND & ND & 80.0 \\
\hline & cpx-host & 48.81 & 1.95 & 4.55 & 0.86 & 6.32 & 0.10 & 15.25 & 20.38 & 0.07 & 0.44 & ND & 0.811 \\
\hline & ol-incl-2 & 38.42 & 0.06 & 0.05 & 0.03 & 18.27 & 0.27 & 41.19 & 0.43 & 0.29 & ND & ND & 80.1 \\
\hline & cpx-host & 48.70 & 1.76 & 3.98 & 0.70 & 6.16 & 0.14 & 15.69 & 20.33 & 0.07 & 0.43 & ND & 0.820 \\
\hline \multirow[t]{2}{*}{12} & ol-incl & 37.90 & 0.04 & 0.05 & 0.05 & 18.45 & 0.27 & 41.01 & 0.43 & 0.32 & ND & ND & 79.8 \\
\hline & cpx-host & 49.15 & 1.97 & 4.24 & 0.67 & 6.72 & 0.14 & 15.61 & 19.91 & 0.05 & 0.45 & ND & 0.805 \\
\hline \multirow[t]{2}{*}{16} & ol-incl & 38.16 & 0.05 & 0.06 & 0.05 & 17.56 & 0.25 & 41.50 & 0.43 & 0.33 & ND & ND & 80.8 \\
\hline & cpx-host & 49.06 & 1.71 & 4.29 & 0.96 & 6.33 & 0.15 & 15.69 & 20.23 & 0.07 & 0.43 & ND & 0.815 \\
\hline $157-953 \mathrm{C}-$ & & & & & & & & & & & & & \\
\hline $\begin{array}{l}93 \mathrm{R}-5,13-27 \\
70\end{array}$ & ol-incl & 38.45 & 0.05 & 0.06 & 0.06 & 18.98 & 0.27 & 40.82 & 0.41 & 0.29 & ND & ND & 79.3 \\
\hline & cpx-host & 49.55 & 1.98 & 4.07 & 0.80 & 6.99 & 0.11 & 16.03 & 19.70 & 0.09 & 0.44 & ND & 0.804 \\
\hline
\end{tabular}


Appendix Table 2 (continued).

\begin{tabular}{|c|c|c|c|c|c|c|c|c|c|c|c|c|c|}
\hline Sample & Phase & $\mathrm{SiO}_{2}$ & $\mathrm{TiO}_{2}$ & $\mathrm{Al}_{2} \mathrm{O}_{3}$ & $\mathrm{Cr}_{2} \mathrm{O}_{3}$ & $\mathrm{FeO}_{\text {tot }}$ & $\mathrm{MnO}$ & $\mathrm{MgO}$ & $\mathrm{CaO}$ & $\mathrm{NiO}$ & $\mathrm{Na}_{2} \mathrm{O}$ & $\mathrm{K}_{2} \mathrm{O}$ & $\mathrm{Mg \# ,An}$ \\
\hline \multicolumn{14}{|l|}{$\begin{array}{l}157-953 \mathrm{C}- \\
93 \mathrm{R}-6,45-55\end{array}$} \\
\hline \multirow[t]{2}{*}{19} & cpx-incl & 50.26 & 1.80 & 3.70 & 0.67 & 6.95 & 0.11 & 15.00 & 21.21 & tr. & 0.41 & ND & 0.794 \\
\hline & ol-host & 38.16 & 0.03 & 0.06 & 0.03 & 17.50 & 0.25 & 42.32 & 0.30 & 0.32 & ND & ND & 81.2 \\
\hline \multirow[t]{2}{*}{34} & cpx-incl & 50.71 & 1.39 & 3.35 & 1.06 & 6.60 & 0.14 & 16.66 & 19.81 & 0.10 & 0.43 & ND & 0.818 \\
\hline & ol-host & 39.18 & 0.05 & 0.05 & 0.03 & 17.94 & 0.24 & 42.31 & 0.31 & 0.34 & ND & ND & 80.8 \\
\hline \multicolumn{14}{|l|}{$\begin{array}{l}157-953 \mathrm{C}- \\
97 \mathrm{R}-2,0-16\end{array}$} \\
\hline \multirow[t]{2}{*}{71} & ol-incl & 38.51 & 0.04 & 0.04 & 0.05 & 17.06 & 0.25 & 42.16 & 0.33 & 0.26 & ND & ND & 81.5 \\
\hline & cpx-host & 50.77 & 1.22 & 2.76 & 0.61 & 6.23 & 0.16 & 16.76 & 20.02 & 0.02 & 0.38 & ND & 0.828 \\
\hline \multirow[t]{4}{*}{82} & ol-incl-1 & 38.51 & 0.06 & 0.05 & 0.07 & 18.00 & 0.25 & 41.40 & 0.40 & 0.28 & ND & ND & 80.4 \\
\hline & ol-incl-2 & 38.55 & 0.06 & 0.05 & 0.05 & 17.95 & 0.24 & 41.56 & 0.39 & 0.29 & ND & ND & 80.5 \\
\hline & ol-incl-3 & 38.23 & 0.06 & 0.05 & 0.04 & 17.93 & 0.23 & 41.35 & 0.42 & 0.29 & ND & ND & 80.4 \\
\hline & cpx-host & 49.72 & 1.73 & 3.76 & 0.68 & 6.27 & 0.12 & 15.63 & 20.37 & 0.04 & 0.40 & ND & 0.816 \\
\hline \multicolumn{14}{|l|}{$157-953 \mathrm{C}-$} \\
\hline \multicolumn{14}{|l|}{ 98R-1, 0-12 } \\
\hline 62 & cpx-host & 50.59 & 1.31 & 2.96 & 0.49 & 6.51 & 0.16 & 16.62 & 19.71 & 0.06 & 0.40 & ND & 0.820 \\
\hline \multicolumn{14}{|l|}{ 157-953C- } \\
\hline \multicolumn{14}{|l|}{$102 \mathrm{R}-1,8-28$} \\
\hline \multirow[t]{2}{*}{3} & ol-incl & 38.66 & 0.04 & 0.09 & 0.07 & 17.62 & 0.27 & 41.81 & 0.36 & 0.29 & ND & ND & 80.9 \\
\hline & cpx-host & 50.58 & 1.43 & 2.93 & 0.66 & 6.17 & 0.15 & 15.93 & 20.17 & 0.02 & 0.39 & ND & 0.821 \\
\hline \multirow[t]{2}{*}{11} & ol-incl & 38.89 & 0.04 & 0.05 & 0.05 & 17.88 & 0.29 & 42.13 & 0.38 & 0.26 & ND & ND & 80.8 \\
\hline & cpx-host & 50.45 & 1.45 & 2.97 & 0.68 & 5.89 & 0.11 & 15.78 & 21.05 & 0.06 & 0.40 & ND & 0.827 \\
\hline \multirow[t]{2}{*}{14} & ol-incl & 38.14 & 0.04 & 0.03 & 0.04 & 17.78 & 0.26 & 41.42 & 0.43 & 0.24 & ND & ND & 80.6 \\
\hline & cpx-host & 50.65 & 1.40 & 2.87 & 0.56 & 6.03 & 0.13 & 15.79 & 20.75 & 0.07 & 0.40 & ND & 0.823 \\
\hline \multirow[t]{2}{*}{27} & ol-incl & 38.20 & 0.08 & 0.05 & 0.05 & 18.73 & 0.29 & 40.98 & 0.38 & 0.23 & ND & ND & 79.6 \\
\hline & cpx-host & 49.81 & 1.68 & 3.58 & 0.63 & 6.49 & 0.14 & 15.53 & 20.38 & 0.03 & 0.42 & ND & 0.810 \\
\hline \multicolumn{14}{|l|}{$\begin{array}{l}\text { 157-956B- } \\
\text { 45R-3, 120-132 }\end{array}$} \\
\hline & pl-incl & & 0.15 & 30.69 & ND & 1.00 & ND & 0.08 & 13.85 & ND & 3.54 & 0.18 & 68.4 \\
\hline & cpx-host & 49.52 & 1.60 & 3.79 & 0.26 & 6.71 & 0.15 & 15.47 & 20.85 & 0.01 & 0.42 & ND & 0.804 \\
\hline \multirow{2}{*}{\multicolumn{14}{|c|}{$\begin{array}{l}\text { 157-956B- } \\
\text { 45R-CC, 7-17 }\end{array}$}} \\
\hline & & & & & & & & & & & & & \\
\hline & cpx-host & 48.76 & $\begin{array}{l}0.11 \\
1.66\end{array}$ & $\begin{array}{r}32.50 \\
3.95\end{array}$ & 0.27 & $\begin{array}{l}0.04 \\
7.16\end{array}$ & 0.12 & 14.86 & 20.79 & 0.03 & $\begin{array}{l}1.01 \\
0.43\end{array}$ & ND & $\begin{array}{r}0.1 \\
0.787\end{array}$ \\
\hline \multirow[t]{2}{*}{72} & pl-incl & 49.49 & 0.14 & 32.42 & ND & 0.88 & ND & 0.05 & 15.42 & ND & 2.74 & 0.08 & 75.7 \\
\hline & cpx-host & 49.51 & 1.84 & 4.25 & 0.31 & 6.96 & 0.14 & 15.05 & 21.31 & 0.06 & 0.38 & ND & 0.794 \\
\hline
\end{tabular}

Notes: Sample $=$ sample studied (core, grain, interval $[\mathrm{cm}]$, analyzed grain). $\mathrm{FeO}_{\mathrm{tot}}=$ measured with electron microprobe, $\mathrm{Mg} \#=\mathrm{mol} \% \mathrm{Fo}$ in olivine, atomic ratio $\mathrm{Mg} /(\mathrm{Mg}+\mathrm{Fe}$ tot $)$ in clinopyroxene. $\mathrm{An}=\operatorname{mol} \%$ An in plagioclase, ol-incl = inclusions of olivine, $\mathrm{cpx}$-incl $=$ inclusions of clinopyroxene, $\mathrm{pl}$-incl $=$ inclusions of plagioclase, $\mathrm{cpx}$-host $=$ host clinopyroxene, and ol-host $=$ host olivine. $\mathrm{ND}=$ not determined, and tr. $=$ traces. 


\begin{tabular}{|c|c|c|c|c|c|c|c|c|c|c|c|c|c|c|c|c|c|c|c|c|c|c|}
\hline Sample & Phase & $\mathrm{SiO}_{2}$ & $\mathrm{TiO}_{2}$ & $\mathrm{Al}_{2} \mathrm{O}_{3}$ & $\mathrm{Cr}_{2} \mathrm{O}_{3}$ & $\mathrm{Fe}_{2} \mathrm{O}_{3}$ & $\mathrm{FeO}$ & $\mathrm{MnO}$ & $\mathrm{MgO}$ & $\mathrm{CaO}$ & $\mathrm{Na}_{2} \mathrm{O}$ & $\mathrm{K}_{2} \mathrm{O}$ & $\mathrm{P}_{2} \mathrm{O}_{5}$ & Total & Mg\#, Fo & $\mathrm{T}\left({ }^{\circ} \mathrm{C}\right)$ & $\mathrm{P}(\mathrm{kbar})$ & $\lg f_{\mathrm{O} 2}$ & $\mathrm{Ol}_{\text {add }}$ & $\mathrm{Cpx}_{\mathrm{add}}$ & $\mathrm{K}_{2} \mathrm{O} / \mathrm{TiO}_{2}$ & $\mathrm{P}_{2} \mathrm{O}_{5} / \mathrm{TiC}$ \\
\hline \multicolumn{23}{|l|}{$\begin{array}{c}157-953 \mathrm{C}- \\
82 \mathrm{R}-1,52-82\end{array}$} \\
\hline \multirow[t]{2}{*}{$57 \mathrm{a}$} & $\begin{array}{l}\mathrm{gl} \\
\mathrm{mlt}\end{array}$ & $\begin{array}{l}45.63 \\
47.4\end{array}$ & $\begin{array}{l}4.52 \\
4.1\end{array}$ & $\begin{array}{l}13.49 \\
12.6\end{array}$ & $\begin{array}{l}0.02 \\
0.02\end{array}$ & $\overline{2.3}$ & $\begin{array}{l}11.95 \\
9.8\end{array}$ & $\begin{array}{l}0.17 \\
0.15\end{array}$ & $\begin{array}{l}5.24 \\
6.7\end{array}$ & $\begin{array}{c}9.82 \\
11.1\end{array}$ & $\begin{array}{l}3.76 \\
3.4\end{array}$ & $\begin{array}{l}2.05 \\
1.9\end{array}$ & $\begin{array}{l}0.71 \\
0.7\end{array}$ & $\begin{array}{l}97.36 \\
100.0\end{array}$ & $\begin{array}{l}0.439 \\
0.548\end{array}$ & $\overline{1207}$ & $\overline{6.1}$ & $-\overline{8.1}$ & $\overline{0}$ & $\overline{11.3}$ & $0 . \overline{45}$ & $0 . \overline{16}$ \\
\hline & cpx & 48.47 & 2.16 & 4.50 & 0.40 & - & 6.57 & 0.12 & 14.49 & 21.54 & 0.48 & ND & ND & 98.72 & 0.797 & - & - & - & - & - & - & - \\
\hline \multirow[t]{6}{*}{$57 \mathrm{~b}$} & $\begin{array}{l}\text { gl-1 } \\
\text { mlt-1 }\end{array}$ & $\begin{array}{l}48.04 \\
49.2\end{array}$ & $\begin{array}{l}4.04 \\
3.5\end{array}$ & $\begin{array}{l}14.38 \\
12.9\end{array}$ & 0.06 & $\overline{1.9}$ & $\begin{array}{c}10.48 \\
8.5\end{array}$ & $\begin{array}{l}0.21 \\
0.18\end{array}$ & $\begin{array}{l}5.01 \\
67\end{array}$ & 9.84 & 3.88 & 1.89 & 0.71 & 98.54 & $\begin{array}{l}0.460 \\
0.586\end{array}$ & $\overline{1194}$ & $\overline{39}$ & $\overline{82}$ & $\overline{0}$ & $\overline{143}$ & $0 \overline{47}$ & $0 . \overline{18}$ \\
\hline & gl-2 & 47.81 & 4.31 & 14.26 & 0.04 & - & 11.30 & 0.15 & $\begin{array}{l}0.1 \\
4.98\end{array}$ & $\begin{array}{c}11.4 \\
8.86\end{array}$ & $\begin{array}{l}3.4 \\
4.11\end{array}$ & $\begin{array}{l}1.6 \\
2.04\end{array}$ & $\begin{array}{l}0.6 \\
0.77\end{array}$ & $\begin{array}{c}100.0 \\
98.64\end{array}$ & $\begin{array}{l}0.586 \\
0.440\end{array}$ & 1194 & 3.9 & -8.2 & - & $\begin{array}{ll}14.3 \\
-\end{array}$ & 0.41 & -10 \\
\hline & mlt-2 & 49.1 & 3.6 & 12.5 & 0.03 & 2.1 & 9.1 & 0.13 & 7.2 & 10.6 & 3.5 & 1.7 & 0.7 & 100.0 & 0.584 & 1231 & 7.3 & -7.8 & 0 & 17.0 & 0.47 & 0.18 \\
\hline & gl-3 & 46.97 & 4.17 & 13.95 & 0.03 & - & 11.26 & 0.15 & 5.17 & 9.99 & 3.74 & 1.75 & 0.64 & 97.83 & 0.450 & $-\overline{0}$ & - & - & - & & & \\
\hline & mlt-3 & 48.7 & 3.6 & 12.5 & 0.03 & 2.0 & 9.1 & 0.13 & 7.1 & 11.7 & 3.2 & 1.5 & 0.6 & 100.0 & 0.582 & 1203 & 4.3 & -8.1 & 0 & 15.9 & 0.42 & 0.15 \\
\hline & cpx & 48.94 & 1.66 & 3.64 & 0.73 & - & 5.76 & 0.10 & 15.18 & 21.68 & 0.46 & ND & ND & $\begin{array}{r}98.15 \\
07\end{array}$ & 0.824 & - & - & - & - & - & - & - \\
\hline \multirow[t]{3}{*}{60} & $\mathrm{gl}$ & 44.87 & 5.03 & 13.11 & tr. & $\overline{21}$ & 12.86 & 0.24 & 5.46 & 10.88 & 3.26 & 1.42 & 0.71 & 97.83 & 0.431 & $\overline{1017}$ & $\overline{35}$ & $\overline{80}$ & $\overline{0}$ & $\overline{48}$ & $\overline{0 x}$ & $\overline{14}$ \\
\hline & mlt & 47.5 & 3.9 & 10.8 & tr. & 2.1 & 9.8 & 0.18 & 8.3 & 13.3 & 2.5 & 1.1 & 0.5 & 100.0 & 0.601 & 1217 & 3.5 & -8.0 & 0 & 24.8 & 0.28 & 0.14 \\
\hline & $\operatorname{cpx}$ & 49.90 & 1.39 & 2.75 & 0.58 & - & 5.29 & 0.12 & 15.77 & 22.01 & 0.40 & ND & ND & 98.21 & 0.842 & - & - & - & - & - & - & - \\
\hline \multicolumn{23}{|l|}{$\begin{array}{l}157-953 \mathrm{C}- \\
82 \mathrm{R}-1,94-103\end{array}$} \\
\hline & $\mathrm{gl}$ & 47.01 & 5.23 & 12.41 & 0.04 & - & 9.23 & 0.17 & 5.93 & 10.37 & 3.28 & 1.38 & 0.73 & 95.78 & 0.534 & - & - & - & - & - & - & - \\
\hline & $\mathrm{mlt}$ & 49.5 & 4.7 & 11.6 & 0.04 & 1.6 & 7.7 & 0.15 & 7.7 & 12.0 & 3.0 & 1.3 & 0.7 & 100.0 & 0.640 & 1218 & 4.5 & -8.0 & 0 & 13.0 & 0.26 & 0.14 \\
\hline & cpx & 50.74 & 0.99 & 2.59 & 0.91 & - & 4.79 & 0.09 & 16.47 & 21.31 & 0.47 & ND & ND & 98.36 & 0.860 & - & - & - & - & - & - & - \\
\hline \multirow[t]{3}{*}{68} & $\mathrm{gl}$ & 43.61 & 4.46 & 12.89 & 0.03 & - & 13.95 & 0.18 & 5.39 & 10.32 & 3.07 & 1.41 & 0.68 & 96.00 & 0.408 & - & - & - & - & - & - & - \\
\hline & mlt & 48.4 & 2.8 & 9.1 & 0.02 & 2.0 & 9.7 & 0.11 & 10.2 & 14.4 & 1.9 & 0.9 & 0.4 & 100.0 & 0.653 & 1266 & 4.5 & -7.5 & 0 & 39.8 & 0.32 & 0.15 \\
\hline & cpx & 52.07 & 0.88 & 1.67 & 0.46 & - & 4.15 & 0.09 & 16.96 & 22.43 & 0.32 & ND & ND & 99.04 & 0.879 & - & - & - & - & - & - & - \\
\hline \multirow[t]{3}{*}{69} & $\mathrm{gl}$ & 43.63 & 5.09 & 12.20 & 0.08 & - & 14.11 & 0.25 & 6.09 & 10.97 & 3.37 & 1.26 & 0.68 & 97.71 & 0.435 & $\overline{-}$ & - & $\overline{-1}$ & - & - & $\overline{0}$ & $-\overline{-}$ \\
\hline & mlt & 46.4 & 4.1 & 10.3 & 0.06 & 2.4 & 10.9 & 0.20 & 8.6 & 13.0 & 2.7 & 1.0 & 0.5 & 100.0 & 0.585 & 1246 & 6.6 & -7.6 & 0 & 21.6 & 0.25 & 0.13 \\
\hline & $\operatorname{cpx}$ & 50.13 & 1.42 & 3.17 & 0.60 & - & 5.69 & 0.13 & 15.77 & 21.26 & 0.44 & ND & ND & 98.61 & 0.832 & - & - & - & - & - & - & - \\
\hline 157-953C- & & & & & & & & & & & & & & & & & & & & & & \\
\hline $\begin{array}{l}83 R-7,0-12 \\
47 a\end{array}$ & & & & & & - & & & & & & & & 99.31 & 0.422 & - & - & & - & - & & - \\
\hline & mlt & 50.7 & 3.3 & 11.4 & 0.04 & 2.1 & 9.7 & 0.14 & 8.3 & 11.1 & 2.2 & 0.7 & 0.3 & 100.0 & 0.603 & 1217 & 3.8 & -7.7 & 0 & 24.6 & $0 . \overline{20}$ & 0.10 \\
\hline & cpx & 50.60 & 1.13 & 2.45 & 0.65 & - & 5.81 & 0.12 & 17.39 & 19.82 & 0.37 & ND & ND & 98.34 & 0.842 & - & - & - & - & - & - & - \\
\hline $47 \mathrm{~b}$ & $\mathrm{gl}$ & 49.11 & 4.51 & 14.57 & 0.04 & - & 12.87 & 0.20 & 4.67 & 8.53 & 3.21 & 0.98 & 0.48 & 99.18 & 0.392 & - & - & - & - & - & - & - \\
\hline & mlt & 50.1 & 3.4 & 11.9 & 0.03 & 2.2 & 10.0 & 0.15 & 8.0 & 10.9 & 2.4 & 0.7 & 0.4 & 100.0 & 0.587 & 1209 & 3.9 & -7.7 & 0 & 25.9 & 0.22 & 0.11 \\
\hline & cpx & 49.73 & 1.37 & 3.36 & 0.79 & - & 6.07 & 0.17 & 16.64 & 19.70 & 0.39 & ND & ND & 98.23 & 0.830 & - & - & - & - & - & - & - \\
\hline 157-953C- & & & & & & & & & & & & & & & & & & & & & & \\
\hline & & & & & & & & & & & & & & & & & - & - & - & - & & \\
\hline & $\begin{array}{l}\text { mlt } \\
\text { mlt }\end{array}$ & & $\begin{array}{l}3.6 \\
3.6\end{array}$ & 12.3 & 0.04 & $\overline{2.2}$ & 9.6 & 0.13 & 7.7 & 11.2 & $\begin{array}{l}2.04 \\
2.4\end{array}$ & 1.0 & 0.4 & 100.0 & 0.589 & 1207 & 4.3 & -7.8 & 0 & 17.7 & 0.27 & 0.11 \\
\hline & $\mathrm{cpx}$ & 50.60 & 1.31 & 2.81 & 0.66 & - & 6.19 & 0.17 & 16.81 & 19.87 & 0.39 & ND & ND & 98.81 & 0.829 & - & - & - & - & - & - & - \\
\hline $23 b$ & & 47.26 & 4.67 & 13.54 & 0.01 & - & 12.49 & 0.18 & 5.99 & 9.87 & 2.77 & 1.08 & 0.47 & 98.33 & 0.461 & $\overline{10}$ & $\overline{53}$ & $\overline{73}$ & $\overline{0}$ & $\overline{2}$ & $\overline{023}$ & $\overline{0}$ \\
\hline & mlt-1 & 49.6 & 3.2 & 10.4 & 0.01 & 1.8 & 9.0 & 0.12 & 10.1 & 12.9 & $\begin{array}{l}1.9 \\
.05\end{array}$ & 0.7 & 0.3 & 100.0 & 0.665 & 1262 & 5.3 & -7.3 & 0 & 32.6 & 0.23 & 0.10 \\
\hline & & 45.74 & 4.71 & 13.00 & 0.07 & - & 13.70 & 0.17 & 6.36 & 9.80 & 2.95 & 1.05 & 0.41 & 97.96 & 0.453 & - & - & - & - & - & & \\
\hline & mlt-2 & & 3.1 & 9.7 & 0.05 & 2.0 & 9.7 & 0. & 10.7 & 12. & 2.0 & 0.7 & 0.3 & 100.0 & 0.662 & 1293 & 7.9 & -7.1 & 0 & 34.4 & 0.22 & 0.09 \\
\hline & cpx & 51. & 1.04 & 2.39 & 0.82 & - & 4.21 & 0.12 & $\begin{array}{l}17.72 \\
\end{array}$ & 20. & 0.33 & ND & ND & 98.36 & 0.882 & - & - & - & - & - & - & - \\
\hline 26 & $\mathrm{gl}$ & 48. & 3.7 & 13.74 & 0.04 & - & 11.32 & 0.16 & 6.07 & 10. & 3. & 1.09 & 0.53 & 98.74 & 0.489 & - & - & - & - & - & - & - \\
\hline & mlt & 49. & 3 & 12.5 & 0.03 & 2.0 & 9.1 & 0.14 & 7.7 & 12 & 2. & 1.0 & 0.5 & 100.0 & 0.601 & 1205 & 3.6 & -7.9 & 0 & 13.7 & 0.29 & 0.14 \\
\hline & & 49.84 & 1.34 & 3.48 & 0.94 & - & 5.55 & 0.11 & 16.04 & 20.89 & 0.44 & ND & ND & 98.63 & 0.838 & - & - & - & - & - & - & - \\
\hline 36 & gl-1 & 46.56 & 4.11 & 14.82 & 0.01 & - & 12.05 & 0.20 & 5.07 & 9.97 & 3.12 & 1.25 & 0.53 & 97.68 & 0.429 & - & - & - & - & - & - & - \\
\hline & & 48.2 & 3.6 & 13.6 & 0.01 & 2.3 & 9.7 & 0.18 & 6.8 & 11.4 & 2.7 & 1.1 & 0.5 & 100.0 & 0.553 & 1177 & 3.2 & -8.2 & 0 & 14.3 & 0.30 & 0.13 \\
\hline & & 46.75 & 4.12 & 14.40 & tr. & - & 11.95 & 0.1 & 5.37 & 10. & 3.10 & 1.21 & 0.58 & 97.87 & 0.445 & & & 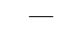 & - & . & . & \\
\hline & mlt-2 & 48.2 & 3.7 & 13.4 & tr. & 2.3 & 9.7 & 0.15 & 6.7 & 11.4 & 2.8 & 1.1 & 0.5 & 100.0 & 0.553 & 1179 & 3.4 & -8.2 & 0 & 11.6 & 0.29 & 0.14 \\
\hline & gl-3 & 46.82 & 4.35 & 14.63 & 0.02 & $\overline{-1}$ & 12.41 & 0.17 & 5.02 & 9.71 & 3.23 & 1.27 & 0.55 & 98.16 & 0.419 & $\overline{11}$ & $\overline{27}$ & $\overline{81}$ & $\overline{0}$ & & & \\
\hline & mlt-3 & 48.3 & 3.7 & 13.1 & 0.02 & 2.4 & 9.9 & 0.15 & 6.9 & 11.2 & 2.8 & 1.1 & 0.5 & 100.0 & 0.552 & 1184 & 3.7 & -8.1 & 0 & 15.6 & 0.29 & 0.13 \\
\hline & cpx & 47.33 & 2.14 & 5.51 & 0.69 & - & 6.49 & 0.12 & 14.57 & 20.88 & 0.49 & ND & ND & 98.23 & 0.800 & - & - & - & - & - & - & \\
\hline $\begin{array}{l}157-953 \mathrm{C}- \\
90 \mathrm{R}-1.82\end{array}$ & & & & & & & & & & & & & & & & & & & & & & \\
\hline & & & 4.34 & & 0.04 & - & 11.05 & 0.16 & & 10.42 & 2.74 & 1.06 & 0.53 & 98.05 & 0.495 & - & - & - & - & - & - & - \\
\hline & mlt-1 & 49.4 & 4.1 & 12.9 & 0.04 & 2.1 & 9.1 & 0.15 & 6.9 & 11.2 & 2.6 & 1.0 & 0.5 & 100.0 & 0.574 & 1183 & 3.3 & -8.1 & 0 & 6.6 & 0.24 & 0.12 \\
\hline & & 49.27 & 4.21 & 13.39 & 0.0 & 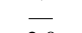 & 10.71 & 0.1 & 6.0 & 10.35 & 2.88 & 1.10 & 0.48 & 98. & 0.5 & . & - & & - & & & \\
\hline & mlt-2 & & 4.0 & 13. & & 2.0 & 8.8 & 0.1 & 6. & 10 & & 1. & 0.5 & 100 & 73 & 1180 & 3.1 & -8.2 & 0 & 5.3 & 0.26 & 0.11 \\
\hline & & & 1.5 & 3. & & - & 6. & & 16. & & 0. & & $\mathrm{Nl}$ & & 4 & - & - & - & - & - & - & - \\
\hline 14 & gl & 47.42 & 4.30 & 13.99 & & - & 12.07 & 0.2 & 5.79 & 10.27 & 2.77 & 0.92 & 0.42 & 98 & 0.461 & - & - & - & - & - & - & $\overline{-}$ \\
\hline & mlt-1 & & 3.7 & 12.7 & $0 .($ & 2.2 & 9. & 0. & 7.6 & 11 & 2. & 0. & 0.4 & 100 & 0.582 & 1194 & 3.4 & -8.0 & 0 & 14.9 & 0.21 & 0.10 \\
\hline & gl-2 & & 4.31 & 13.70 & 0.05 & 20 & 12. & 0. & 6. & & 2. & 0. & 0.44 & & 0.464 & 1203 & $\overline{39}$ & & $\overline{0}$ & $\overline{144}$ & & \\
\hline & mlt-2 & 48.4 & 3.7 & 12.4 & 0.04 & 2.2 & 10.0 & 0.17 & 7.8 & 11.8 & 2.4 & 0.8 & 0.4 & 100.0 & 0.581 & 1203 & 3.9 & -7.9 & 0 & 14.4 & 0.21 & 0.10 \\
\hline & $\mathrm{cpx}$ & 49.64 & 1.59 & 3.74 & 0.76 & - & 6.05 & 0.14 & 15.89 & 20.45 & 0.39 & ND & ND & 98.65 & 0.824 & - & - & - & - & - & - & - \\
\hline
\end{tabular}


Appendix Table 3 (continued).

\begin{tabular}{|c|c|c|c|c|c|c|c|c|c|c|c|c|c|c|c|c|c|c|c|c|c|c|}
\hline Sample & Phase & $\mathrm{SiO}_{2}$ & $\mathrm{TiO}_{2}$ & $\mathrm{Al}_{2} \mathrm{O}_{3}$ & $\mathrm{Cr}_{2} \mathrm{O}_{3}$ & $\mathrm{Fe}_{2} \mathrm{O}_{3}$ & $\mathrm{FeO}$ & $\mathrm{MnO}$ & $\mathrm{MgO}$ & $\mathrm{CaO}$ & $\mathrm{Na}_{2} \mathrm{O}$ & $\mathrm{K}_{2} \mathrm{O}$ & $\mathrm{P}_{2} \mathrm{O}_{5}$ & Total & Mg\#, Fo & $\mathrm{T}\left({ }^{\circ} \mathrm{C}\right)$ & P (kbar) & $\lg f_{\mathrm{O} 2}$ & $\mathrm{Ol}_{\mathrm{add}}$ & $\mathrm{Cpx}_{\mathrm{add}}$ & $\mathrm{K}_{2} \mathrm{O} / \mathrm{TiO}_{2}$ & $\mathrm{P}_{2} \mathrm{O}_{5} / \mathrm{TiO}_{2}$ \\
\hline 16 & $\begin{array}{l}\mathrm{gl} \\
\mathrm{mlt} \\
\mathrm{cpx}\end{array}$ & $\begin{array}{l}46.90 \\
48.4 \\
48.64\end{array}$ & $\begin{array}{l}4.78 \\
3.7 \\
1.60\end{array}$ & $\begin{array}{c}14.73 \\
12.4 \\
4.15\end{array}$ & $\begin{array}{l}0.07 \\
0.05 \\
0.77\end{array}$ & $\overline{2.4}$ & $\begin{array}{c}13.63 \\
10.6 \\
6.45\end{array}$ & $\begin{array}{l}0.21 \\
0.16 \\
0.11\end{array}$ & $\begin{array}{c}5.08 \\
7.9 \\
15.98\end{array}$ & $\begin{array}{c}8.91 \\
10.8 \\
19.93\end{array}$ & $\begin{array}{l}3.01 \\
2.4 \\
0.44\end{array}$ & $\begin{array}{l}1.09 \\
0.9 \\
\mathrm{ND}\end{array}$ & $\begin{array}{l}0.48 \\
0.4 \\
\text { ND }\end{array}$ & $\begin{array}{c}98.89 \\
100.0 \\
98.07\end{array}$ & $\begin{array}{l}0.399 \\
0.569 \\
0.815\end{array}$ & $\overline{1214}$ & $\overline{5.5}$ & $-\overline{-7.7}$ & $\overline{0}$ & $2 \overline{2.3}$ & $0 . \overline{23}$ & $0 . \overline{10}$ \\
\hline
\end{tabular}

157-953C-

93R-6, 45-55

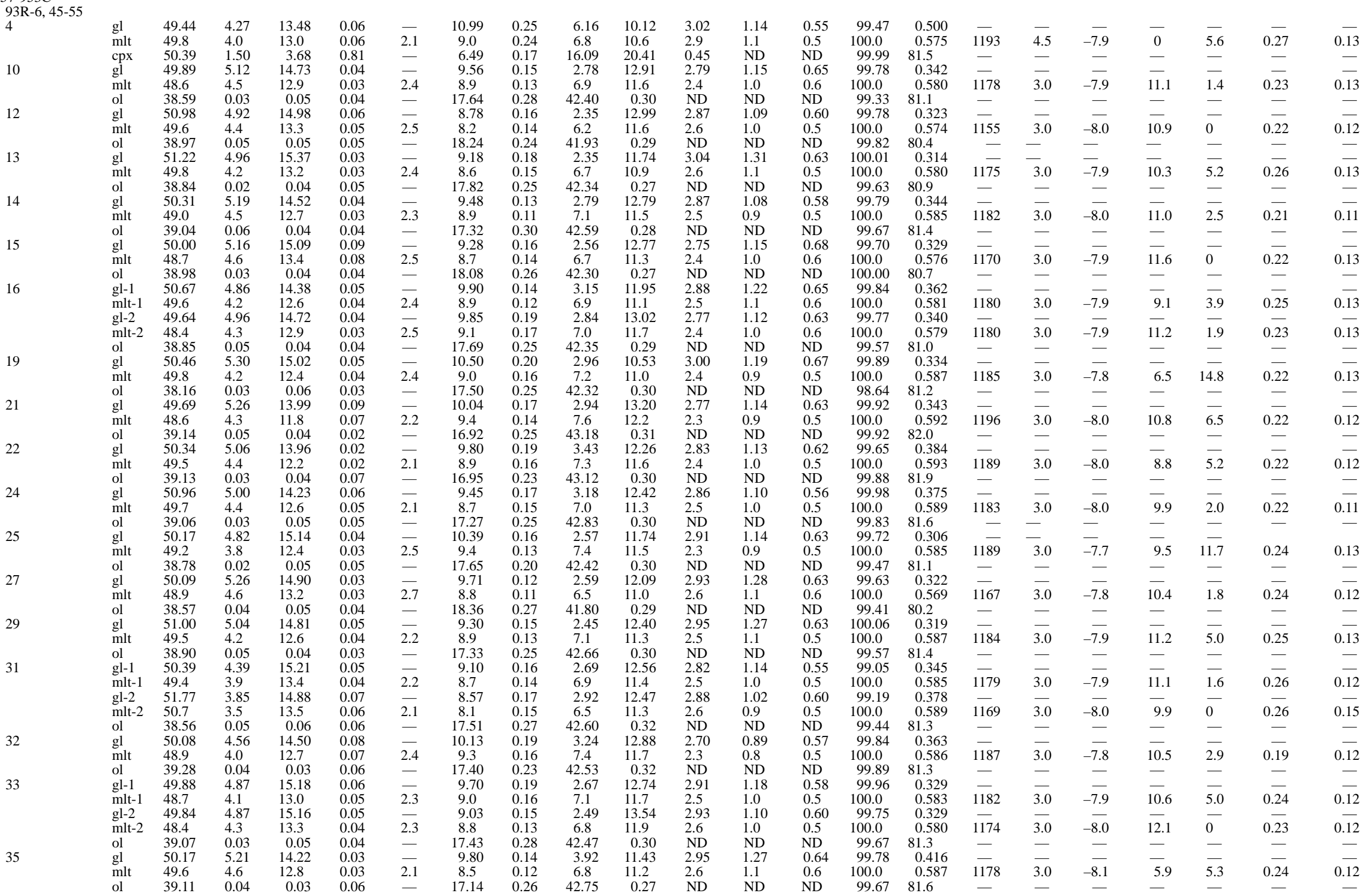


Appendix Table 3 (continued).

\begin{tabular}{|c|c|c|c|c|c|c|c|c|c|c|c|c|c|c|c|c|c|c|c|c|c|c|}
\hline Sample & Phase & $\mathrm{SiO}_{2}$ & $\mathrm{TiO}_{2}$ & $\mathrm{Al}_{2} \mathrm{O}_{3}$ & $\mathrm{Cr}_{2} \mathrm{O}_{3}$ & $\mathrm{Fe}_{2} \mathrm{O}_{3}$ & $\mathrm{FeO}$ & $\mathrm{MnO}$ & $\mathrm{MgO}$ & $\mathrm{CaO}$ & $\mathrm{Na}_{2} \mathrm{O}$ & $\mathrm{K}_{2} \mathrm{O}$ & $\mathrm{P}_{2} \mathrm{O}_{5}$ & Total & Mg\#, Fo & $\mathrm{T}\left({ }^{\circ} \mathrm{C}\right)$ & $\mathrm{P}(\mathrm{kbar})$ & $\lg f_{\mathrm{O} 2}$ & $\mathrm{Ol}_{\mathrm{add}}$ & $\mathrm{Cpx}_{\mathrm{add}}$ & $\mathrm{K}_{2} \mathrm{O} / \mathrm{TiO}_{2}$ & $\mathrm{P}_{2} \mathrm{O}_{5} / \mathrm{TiO}$ \\
\hline \multirow[t]{5}{*}{37} & gl-1 & 49.58 & 4.87 & 14.23 & 0.01 & - & 10.31 & 0.17 & 3.42 & 12.27 & 2.81 & 1.13 & 0.61 & 99.41 & 0.372 & - & - & - & - & - & - & - \\
\hline & mlt-1 & 48.9 & 4.2 & 12.4 & 0.01 & 2.3 & 9.2 & 0.15 & 7.3 & 11.7 & 2.4 & 1.0 & 0.5 & 100.0 & 0.586 & 1187 & 3.0 & -7.9 & 8.6 & 6.0 & 0.23 & 0.12 \\
\hline & gl-2 & 49.96 & 4.86 & 14.51 & 0.06 & & 9.79 & 0.13 & 2.82 & 12.95 & 2.73 & 1.05 & 0.60 & 99.47 & 0.339 & & & - & - & - & 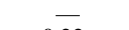 & \\
\hline & mlt-2 & 48.8 & 4.2 & 12.7 & 0.05 & 2.5 & 9.2 & 0.11 & 7.1 & 11.6 & 2.4 & 0.9 & 0.5 & 100.0 & 0.581 & 1182 & 3.0 & -7.8 & 11.6 & 1.5 & 0.22 & 0.12 \\
\hline & ol & 38.55 & 0.04 & 0.05 & 0.06 & - & 17.27 & 0.25 & 42.39 & 0.30 & ND & ND & ND & 98.92 & 81.4 & - & - & - & - & - & - & - \\
\hline \multirow[t]{5}{*}{40} & gl-1 & 50.16 & 5.10 & 15.29 & 0.05 & - & 9.39 & 0.15 & 2.46 & 11.80 & 2.90 & 1.24 & 0.60 & 99.14 & 0.319 & - & - & - & - & - & - & - \\
\hline & mlt-1 & 49.2 & 4.5 & 13.6 & 0.04 & 2.7 & 8.5 & 0.13 & 6.3 & 10.7 & 2.6 & 1.1 & 0.5 & 100.0 & 0.569 & 1163 & 3.0 & -7.7 & 10.4 & 1.5 & 0.24 & 0.12 \\
\hline & gl-2 & 50.01 & 5.16 & 14.43 & 0.08 & - & 10.10 & 0.14 & 2.76 & 12.16 & 2.88 & 1.15 & 0.59 & 99.46 & 0.328 & & & - & - & & & \\
\hline & mlt-2 & 48.9 & 4.5 & 12.8 & 0.07 & 2.9 & 9.0 & 0.12 & 6.7 & 11.0 & 2.5 & 1.0 & 0.5 & 100.0 & 0.569 & 1171 & 3.0 & -7.7 & 10.5 & 1.7 & 0.22 & 0.11 \\
\hline & ol & 38.74 & 0.04 & 0.05 & 0.04 & - & 18.51 & 0.25 & 41.73 & 0.29 & ND & ND & ND & 99.63 & 80.1 & - & - & - & - & - & - & - \\
\hline \multirow[t]{3}{*}{43} & $\mathrm{gl}$ & 49.35 & 5.34 & 13.83 & 0.03 & $\overline{7}$ & 9.11 & 0.17 & 3.24 & 13.80 & 2.51 & 1.10 & 0.62 & 99.12 & 0.388 & $\overline{1}$ & - & - & - & - & $\bar{\Omega}$ & - \\
\hline & mlt & 48.6 & 4.6 & 12.0 & 0.03 & 1.7 & 8.9 & 0.15 & 7.8 & 12.6 & 2.2 & 1.0 & 0.5 & 100.0 & 0.611 & 1200 & 3.0 & -8.3 & 11.1 & 3.6 & 0.21 & 0.12 \\
\hline & ol & 38.60 & 0.04 & 0.06 & 0.03 & - & 15.58 & 0.22 & 43.83 & 0.33 & ND & ND & ND & 98.70 & 83.4 & - & - & - & - & - & - & - \\
\hline \multirow[t]{5}{*}{44} & gl-1 & 51.07 & 5.14 & 14.66 & 0.03 & - & 8.86 & 0.17 & 2.85 & 12.15 & 3.04 & 1.23 & 0.62 & 99.82 & 0.365 & - & - & - & - & - & - & - \\
\hline & mlt-1 & 49.8 & 4.6 & 13.2 & 0.03 & 2.1 & 8.3 & 0.15 & 6.5 & 10.9 & 2.7 & 1.1 & 0.6 & 100.0 & 0.583 & 1172 & 3.0 & -8.1 & 10.0 & 0.2 & 0.24 & 0.12 \\
\hline & gl-2 & 49.65 & 5.17 & 14.82 & 0.03 & & 9.76 & 0.17 & 2.96 & 11.97 & 3.18 & 1.22 & 0.61 & 99.55 & 0.351 & & & & $\bar{c}$ & & & \\
\hline & mlt-2 & 49.0 & 4.4 & 12.9 & 0.03 & 2.3 & 8.8 & 0.14 & 6.8 & 11.5 & 2.7 & 1.0 & 0.5 & 100.0 & 0.581 & 1179 & 3.0 & -8.0 & 8.5 & 6.6 & 0.24 & 0.12 \\
\hline & ol & 38.80 & 0.05 & 0.05 & 0.05 & - & 17.43 & 0.25 & 42.51 & 0.29 & ND & ND & ND & 99.43 & 81.3 & - & - & - & - & - & - & - \\
\hline \multirow[t]{3}{*}{46} & $\mathrm{gl}$ & 50.48 & 5.02 & 13.91 & 0.04 & $\overline{20}$ & 9.79 & 0.19 & 3.53 & 11.62 & 2.93 & 1.21 & 0.61 & 99.34 & 0.391 & - & - & - & - & - & $\overline{-}$ & - \\
\hline & mlt & 49.8 & 4.4 & 12.5 & 0.04 & 2.2 & 8.7 & 0.17 & 6.9 & 11.1 & 2.6 & 1.1 & 0.5 & 100.0 & 0.585 & 1181 & 3.0 & -8.0 & 7.7 & 4.1 & 0.24 & 0.12 \\
\hline & ol & 38.58 & 0.04 & 0.04 & 0.04 & - & 17.41 & 0.26 & 42.35 & 0.28 & ND & ND & ND & 99.01 & 81.3 & - & - & - & - & - & - & - \\
\hline \multicolumn{23}{|l|}{$\begin{array}{l}157-953 \mathrm{C}- \\
97 \mathrm{R}-2,0-16\end{array}$} \\
\hline & gl-1 & 50.23 & 5.25 & 14.12 & 0.03 & - & 12.50 & 0.19 & 4.15 & 8.39 & 2.89 & 1.24 & 0.66 & 99.65 & 0.372 & - & - & - & - & - & - & - \\
\hline & mlt-1 & 50.7 & 3.9 & 11.4 & 0.02 & 2.2 & 9.7 & 0.14 & 7.4 & 10.9 & 2.1 & 0.9 & 0.5 & 100.0 & 0.577 & 1181 & 1.6 & -8.1 & 0 & 26.3 & $0 . \overline{24}$ & 0.13 \\
\hline & $\mathrm{gl}-2$ & 50.65 & 5.49 & 14.34 & 0.02 & 2.2 & 12.04 & & 3.9 & 8.17 & 2.90 & 1.29 & 0.62 & 99.63 & 0.3 & & & & - & & & \\
\hline & mlt-2 & 51.0 & 4.0 & 11.6 & 0.01 & 2.1 & 9.5 & 0.14 & 7.3 & 10.8 & 2.1 & 1.0 & 0.5 & 100.0 & 0.5 & 1178 & 1.5 & -8.1 & 0 & 26.7 & 0.24 & 0.11 \\
\hline & cpx & 51.64 & 1.18 & 2.24 & 0.57 & - & 6.75 & 0.15 & 17.56 & 18.86 & 0.34 & ND & ND & 99.30 & 0.82 & - & - & - & - & - & - & - \\
\hline 66 & gl-1 & 46.56 & 5.13 & 13.41 & 0.05 & - & 12.67 & 0.22 & 5.89 & 10.54 & 2.77 & 1.09 & 0.52 & 98.85 & 0.453 & - & - & - & - & - & - & - \\
\hline & mlt-1 & 47.7 & 4.5 & 12.2 & 0.04 & 2.3 & 10.1 & 0.19 & 7.4 & 11.7 & 2.4 & 1.0 & 0.5 & 100.0 & 0.567 & 1194 & 3.9 & -8.0 & 0 & 13.4 & 0.21 & 0.10 \\
\hline & gl-2 & 47.92 & 4.73 & 13.59 & 0.04 & $\overline{0}$ & 11.86 & 0.22 & 5.57 & 9.96 & 2.90 & 1.18 & 0.55 & 98.50 & 0.456 & - & $\overline{-}$ & - & - & $\overline{7}$ & & \\
\hline & mlt-2 & $\begin{array}{l}49.0 \\
4780\end{array}$ & 4.2 & $\begin{array}{l}12.5 \\
1280\end{array}$ & 0.04 & 2.2 & $\begin{array}{r}9.6 \\
11.76\end{array}$ & 0.19 & 7.1 & 11.2 & 2.6 & 1.0 & 0.5 & $\begin{array}{l}100.0 \\
086\end{array}$ & 0.569 & 1187 & 3.4 & -8.1 & 0 & 12.7 & 0.25 & 0.12 \\
\hline & gl-3 & 47.89 & 4.69 & 13.80 & 0.03 & 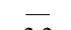 & 11.76 & 0.12 & 5.45 & 10.20 & 2.90 & 1.21 & 0.56 & 98.61 & 0.452 & - & 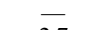 & - & - & 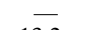 & & \\
\hline & mlt-3 & 48.9 & 4.1 & 12.6 & 0.03 & 2.2 & 9.4 & 0.11 & 7.0 & 11.5 & 2.6 & 1.1 & 0.5 & 100.0 & 0.569 & 1180 & 2.7 & -8.2 & 0 & 13.2 & 0.26 & 0.12 \\
\hline & $\mathrm{cpx}$ & 49.74 & 1.65 & 3.75 & 0.66 & - & 6.39 & 0.14 & 15.55 & 20.49 & 0.42 & ND & ND & 98.78 & 0.813 & - & - & - & - & - & - & - \\
\hline 67 & gl-1 & 47.78 & 4.64 & 13.46 & 0.04 & - & 12.01 & 0.23 & 5.89 & 10.34 & 2.68 & 1.16 & 0.60 & 98.82 & 0.466 & - & - & - & - & - & - & - \\
\hline & mlt-1 & 48.8 & 4.1 & 12.3 & 0.04 & 2.2 & 9.6 & 0.20 & 7.4 & 11.5 & 2.4 & 1.0 & 0.5 & 100.0 & 0.5 & 1193 & 3.4 & -8.0 & 0 & 13.0 & 0.25 & 0.13 \\
\hline & cpx-1 & 50.09 & 1.48 & 3.48 & 0.85 & - & 6.14 & 0.14 & 15.77 & 20.47 & 0.40 & ND & ND & 98.82 & 0.821 & - & - & - & - & - & - & - \\
\hline & $\mathrm{gl}-2$ & 47.73 & 4.56 & 13.04 & 0.04 & - & 12.04 & & 5.89 & 10.23 & 2.72 & 1.19 & 0.57 & 98.23 & 0.466 & - & - & - & - & - & - & - \\
\hline & mlt-2 & 49.2 & 3.9 & 11.6 & 0.0 & 2.1 & 9.6 & 0.18 & 7.8 & 11.8 & 2.3 & 1.0 & 0.5 & 100.0 & 0.55 & 1204 & 3.4 & -7.9 & 0 & 16.5 & 0.26 & 0.12 \\
\hline & cpx-2 & 50.56 & 1.2 & 2.95 & 0.76 & - & 5.8 & 0. & 16.46 & 20.3 & 0.4 & $\mathrm{Nl}$ & ND & 98.66 & 0.8 & - & - & - & - & - & - & - \\
\hline & gl-3 & 47.30 & 4.59 & 13.18 & tr. & - & 11.82 & 0.19 & 5.80 & 10.38 & 2.76 & 1.15 & 0.58 & 97.75 & & - & - & - & - & - & - & - \\
\hline & mlt-3 & 48.9 & 4.0 & 11.9 & tr. & 2.1 & 9.5 & 0.16 & 7.6 & 11.9 & 2.4 & 1.0 & 0.5 & 100.0 & 0.589 & 1197 & 3.1 & -8.0 & 0 & 15.3 & 0.25 & 0.13 \\
\hline & cpx-3 & 49.61 & 1.40 & 3.28 & 0.88 & - & 5.86 & 0.15 & 16.06 & 20.61 & 0.39 & ND & ND & 98.25 & 0.830 & - & - & - & - & - & - & - \\
\hline 68 & gl & 48.3 & 4.22 & 13.68 & 0.0 & - & 11.00 & 0.21 & 5.79 & 10. & 2.9 & 1.25 & 0.56 & 98.79 & & - & - & - & - & - & - & - \\
\hline & $\mathrm{mlt}$ & 49. & 3.8 & 12. & 0. & 2.0 & 8.9 & & 7.2 & 11. & 2. & 1.1 & 0. & 100.0 & & 1184 & 2.4 & -8.2 & 0 & 11.8 & 0.30 & 0.13 \\
\hline & cpx & 49.78 & 1.64 & 3.59 & 0. & - & 5.78 & 0.12 & 15.60 & 20.78 & 0.39 & ND & ND & 98.59 & 0.8 & - & - & - & - & - & - & - \\
\hline 69 & $\mathrm{gl}$ & 51.08 & 3.82 & 13.45 & 0.09 & - & 10.27 & 0.16 & 5.64 & 9.52 & 2.97 & 0.95 & 0.45 & 98.40 & 0.4 & - & - & - & - & - & - & - \\
\hline . & mlt & 51.9 & 3.4 & 12.4 & 0.08 & 1.8 & 8.3 & 0.14 & 7.3 & 10.9 & 2.6 & 0.8 & 0.4 & 100.0 & 0.609 & 1194 & 2.7 & -8.0 & 0 & 13.3 & 0.25 & 0.12 \\
\hline & cpx & 51.99 & 0.92 & 1.94 & 0.79 & - & 5.93 & 0.17 & 17.75 & 19.16 & 0.37 & ND & ND & 99.03 & 0.842 & - & - & - & - & - & - & - \\
\hline 78 & $\mathrm{gl}$ & 48.99 & 4.53 & 13.47 & 0.01 & - & 12.46 & 0.21 & 5.23 & 8.89 & 2.66 & 1.40 & 0.62 & 98.46 & 0.4 & - & - & - & - & - & - & - \\
\hline & $\mathrm{mlt}$ & 50.2 & 3.7 & 11.6 & 0.01 & 2.2 & 9.8 & & 7.8 & & & & 0.5 & 100.0 & & 1209 & 4.1 & -7.8 & 0 & 20.4 & 0.31 & 0.14 \\
\hline & cpx & 50.43 & 1.26 & 2.82 & 0.57 & - & 6.18 & 0.13 & 16.86 & 20.09 & 0.41 & ND & ND & 98.75 & 0.829 & - & - & - & - & - & - & - \\
\hline 157-953C- & & & & & & & & & & & & & & & & & & & & & & \\
\hline $\begin{array}{l}98 \mathrm{R}-1,0-12 \\
40\end{array}$ & & & & & & & & & & & & & & & & & & & - & & & \\
\hline & $\begin{array}{l}\text { mlt } \\
\text { mlt }\end{array}$ & & & & 0. & 2.2 & & & 7.2 & & 2. & 1.8 (. & $\begin{array}{l}0.49 \\
0.4\end{array}$ & $\begin{array}{l}98.39 \\
100.0\end{array}$ & 0.5 & $\overline{1194}$ & $\overline{3.4}$ & $-\overline{8.0}$ & $\overline{0}$ & $1 \overline{11.9}$ & 0.26 & $0 . \overline{12}$ \\
\hline & сpx & 50.84 & 1.31 & 2.90 & 0.66 & - & 6.37 & 0.16 & 16.27 & 19.74 & 0.38 & ND & ND & 98.63 & 0.820 & - & - & - & - & - & - & - \\
\hline 42 & gl & 48.44 & 4.08 & 13.44 & 0.05 & - & 11.36 & 0.18 & 6.21 & 10.70 & 2.66 & 0.92 & 0.45 & 98.49 & 0.494 & - & - & - & - & - & - & - \\
\hline 72 & mlt & 49.5 & 3.7 & 12.5 & 0.04 & 2.0 & 9.2 & 0.16 & 7.6 & 11.8 & 2.4 & 0.8 & 0.4 & 100.0 & 0.595 & 1193 & 2.7 & -8.0 & 0 & 11.6 & 0.22 & 0.11 \\
\hline & cpx & 50.20 & 1.26 & 3.34 & 0.88 & - & 5.83 & 0.15 & 16.31 & 20.30 & 0.41 & ND & ND & 98.69 & 0.833 & - & - & - & - & - & - & - \\
\hline 43 & gl & 47.95 & 4.64 & 13.47 & 0.04 & - & 12.04 & 0. & 5.74 & 9.85 & 2.91 & 1.35 & 0.62 & 98.79 & 0.4 & - & - & - & - & - & - & 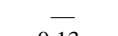 \\
\hline & $\mathrm{mlt}$ & & 4.1 & 12.4 & 0.0 & 2.2 & 9.7 & 0. & 7.2 & 11.0 & 2.6 & 1.2 & 0.6 & 100.0 & 0.56 & 1199 & 4.6 & -8.0 & 0 & 12.0 & 0.29 & 0.13 \\
\hline & cpx & 50.39 & 1.57 & 3.28 & 0.48 & - & 6.60 & 0.15 & 16.09 & 19.94 & 0.42 & ND & ND & 98.92 & 0.813 & - & - & - & - & - & - & - \\
\hline
\end{tabular}


Appendix Table 3 (continued).

\begin{tabular}{|c|c|c|c|c|c|c|c|c|c|c|c|c|c|c|c|c|c|c|c|c|c|c|}
\hline Sample & Phase & $\mathrm{SiO}_{2}$ & $\mathrm{TiO}_{2}$ & $\mathrm{Al}_{2} \mathrm{O}_{3}$ & $\mathrm{Cr}_{2} \mathrm{O}_{3}$ & $\mathrm{Fe}_{2} \mathrm{O}_{3}$ & $\mathrm{FeO}$ & $\mathrm{MnO}$ & $\mathrm{MgO}$ & $\mathrm{CaO}$ & $\mathrm{Na}_{2} \mathrm{O}$ & $\mathrm{K}_{2} \mathrm{O}$ & $\mathrm{P}_{2} \mathrm{O}_{5}$ & Total & Mg\#, Fo & $\mathrm{T}\left({ }^{\circ} \mathrm{C}\right)$ & $\mathrm{P}$ (kbar) & $\lg f_{\mathrm{O} 2}$ & $\mathrm{Ol}_{\text {add }}$ & $\mathrm{Cpx}_{\mathrm{add}}$ & $\mathrm{K}_{2} \mathrm{O} / \mathrm{TiO}_{2}$ & $\mathrm{P}_{2} \mathrm{O}_{5} / \mathrm{TiO}_{2}$ \\
\hline \multirow[t]{3}{*}{44} & $\mathrm{gl}$ & 46.72 & 5.34 & 13.98 & 0.02 & - & 12.31 & 0.16 & 5.69 & 10.39 & 2.72 & 1.19 & 0.57 & 99.09 & 0.452 & - & - & - & - & - & - & - \\
\hline & mlt & 47.7 & 4.7 & 12.7 & 0.02 & 2.3 & 9.8 & 0.14 & 7.2 & 11.6 & 2.4 & 1.0 & 0.5 & 100.0 & 0.567 & 1189 & 3.9 & -8.1 & 0 & 13.4 & 0.22 & 0.11 \\
\hline & cpx & 48.85 & 1.89 & 4.52 & 0.78 & - & 6.29 & 0.13 & 15.13 & 20.72 & 0.43 & ND & ND & 98.73 & 0.811 & - & - & - & - & - & - & - \\
\hline \multirow[t]{5}{*}{47} & gl-1 & 47.69 & 4.96 & 12.70 & 0.10 & - & 11.76 & 0.24 & 6.29 & 10.46 & 2.57 & 1.21 & 0.61 & 98.56 & 0.488 & - & - & - & - & - & - & - \\
\hline & mlt-1 & 48.6 & 4.6 & 12.1 & 0.09 & 2.2 & 9.6 & 0.22 & 7.2 & 11.2 & 2.4 & 1.1 & 0.6 & 100.0 & 0.572 & 1193 & 4.0 & -8.1 & 0 & 7.7 & 0.24 & 0.12 \\
\hline & gl-2 & 48.05 & 4.75 & 12.71 & 0.02 & $\overline{20}$ & 12.37 & 0.13 & 6.34 & 9.93 & 2.58 & 1.06 & 0.58 & 98.53 & 0.477 & - & - & - & - & - & - & \\
\hline & mlt-2 & 49.0 & 4.4 & 12.0 & 0.02 & 2.3 & 10.1 & 0.12 & 7.4 & 10.8 & 2.4 & 1.0 & 0.5 & 100.0 & 0.569 & 1207 & 5.2 & -7.8 & 0 & 9.0 & 0.22 & 0.12 \\
\hline & cpx & 50.45 & 1.52 & 3.03 & 0.55 & - & 6.65 & 0.16 & 16.37 & 19.74 & 0.41 & ND & ND & 98.88 & 0.815 & - & - & - & - & - & - & - \\
\hline \multirow[t]{3}{*}{48} & $\mathrm{gl}$ & 47.62 & 4.48 & 13.84 & tr. & $\overline{00}$ & 11.63 & 0.15 & 5.84 & 10.60 & 2.93 & 1.27 & 0.57 & 98.92 & 0.472 & $-\overline{106}$ & $\overline{2 x}$ & $\bar{a}$ & - & $\overline{0=}$ & $\overline{0}$ & $\overline{-12}$ \\
\hline & mlt & 48.4 & 4.1 & 13.0 & tr. & 2.2 & 9.4 & 0.14 & 6.9 & 11.5 & 2.7 & 1.2 & 0.5 & 100.0 & 0.568 & 1186 & 3.6 & -8.1 & 0 & 9.5 & 0.28 & 0.13 \\
\hline & cpx & 49.10 & 1.78 & 4.46 & 0.83 & - & 6.33 & 0.12 & 15.21 & 20.66 & 0.43 & ND & ND & 98.93 & 0.811 & - & - & - & - & - & - & - \\
\hline \multirow[t]{6}{*}{51} & gl-1 & 48.67 & 4.43 & 14.18 & 0.01 & - & 11.16 & 0.21 & 5.38 & 9.79 & 2.99 & 1.33 & 0.62 & 98.78 & 0.462 & - & - & - & - & - & - & $\overline{-}$ \\
\hline & mlt-1 & $\begin{array}{l}40.01 \\
49.6\end{array}$ & $\begin{array}{l}3.8 \\
3.8\end{array}$ & 12.8 & 0.01 & $\overline{2.0}$ & 9.0 & 0.18 & 7.1 & 11.2 & 2.6 & 1.2 & $\begin{array}{l}0.52 \\
0.5\end{array}$ & $\begin{array}{l}100.0 \\
100\end{array}$ & $\begin{array}{l}0.586 \\
0.586\end{array}$ & $\overline{1189}$ & $\overline{3.4}$ & $-\overline{8.1}$ & $\overline{0}$ & $1 \overline{14.4}$ & $0 . \overline{30}$ & $0 . \overline{14}$ \\
\hline & cpx-1 & 50.12 & 1.47 & 3.33 & 0.84 & - & 6.15 & 0.15 & 16.17 & 20.33 & 0.40 & ND & ND & 98.98 & 0.824 & - & - & - & - & - & - & - \\
\hline & gl-2 & 48.77 & 4.48 & 14.08 & 0.07 & - & 11.14 & 0.16 & 5.50 & 9.86 & 2.97 & 1.27 & 0.58 & 98.87 & 0.468 & - & - & - & - & - & - & - \\
\hline & mlt-2 & 49.6 & 4.0 & 13.0 & 0.06 & 2.1 & 9.0 & 0.14 & 6.9 & 11.0 & 2.6 & 1.1 & 0.5 & 100.0 & 0.578 & 1187 & 3.6 & -8.1 & 0 & 11.9 & 0.28 & 0.13 \\
\hline & cpx-2 & 49.84 & 1.59 & 3.64 & 0.73 & - & 6.33 & 0.13 & 16.00 & 20.26 & 0.39 & ND & ND & 98.92 & 0.818 & - & - & - & - & - & - & - \\
\hline \multirow[t]{3}{*}{52} & $\mathrm{gl}$ & 48.72 & 4.49 & 14.21 & 0.07 & - & 11.09 & 0.16 & 5.41 & 9.69 & 3.03 & 1.27 & 0.61 & 98.73 & 0.465 & - & - & - & - & - & - & - \\
\hline & mlt & 49.7 & 3.9 & 12.8 & 0.06 & 2.0 & 8.9 & 0.14 & 7.2 & 11.1 & 2.6 & 1.1 & 0.5 & 100.0 & 0.591 & 1195 & 3.8 & -8.0 & 0 & 15.0 & 0.28 & 0.14 \\
\hline & cpx & 50.15 & 1.41 & 3.29 & 0.72 & - & 5.91 & 0.13 & 15.96 & 20.40 & 0.41 & ND & ND & 98.38 & 0.828 & - & - & - & - & - & - & - \\
\hline 55 & $\mathrm{gl}$ & 47.33 & 5.23 & 12.85 & 0.07 & & 11.83 & 0.22 & 6.01 & 10.51 & 2.66 & 1.36 & 0.59 & 98.66 & 0.475 & - & - & - & - & - & - & - \\
\hline & mlt & 48.2 & 4.9 & 12.2 & 0.07 & 2.2 & 9.6 & 0.20 & 6.9 & 11.3 & 2.5 & 1.3 & 0.6 & 100.0 & 0.562 & 1185 & 3.7 & -8.2 & 0 & 7.9 & 0.26 & 0.11 \\
\hline & cpx & 49.12 & 1.90 & 3.93 & 0.58 & - & 6.69 & 0.17 & 15.70 & 19.81 & 0.44 & ND & ND & 98.33 & 0.807 & - & - & - & - & - & - & - \\
\hline 57 & gl-1 & 49.20 & 4.63 & 14.18 & tr. & - & 11.23 & 0.18 & 4.81 & 9.23 & 2.58 & 2.08 & 0.63 & 98.75 & 0.433 & - & - & - & - & - & - & - \\
\hline נI & mlt-1 & 50.2 & 3.8 & 12.3 & $\begin{array}{l}\text { u. } \\
\text { tr. }\end{array}$ & $\overline{2.0}$ & 8.9 & 0.15 & $\begin{array}{l}7.01 \\
7.2\end{array}$ & 11.2 & 2.10 & $\begin{array}{l}1.00 \\
1.7\end{array}$ & 0.5 & 100.0 & 0.590 & $\overline{1188}$ & $\overline{2.6}$ & $-\overline{8.1}$ & $\overline{0}$ & $1 \overline{19.6}$ & $0 . \overline{45}$ & $0 . \overline{14}$ \\
\hline & cpx-1 & 50.13 & 1.51 & 3.34 & 0.73 & - & 5.87 & 0.16 & 15.94 & 20.75 & 0.41 & ND & ND & 98.85 & 0.829 & - & - & - & - & - & - & - \\
\hline & gl-2 & 47.93 & $\begin{array}{l}1.01 \\
5.02\end{array}$ & $\begin{array}{r}5.34 \\
13.95\end{array}$ & 0.01 & - & $\begin{array}{r}5.87 \\
12.49\end{array}$ & 0.18 & $\begin{array}{r}1.94 \\
5.12\end{array}$ & $\begin{array}{r}9.13 \\
9.72\end{array}$ & $\begin{array}{l}2.41 \\
2.87\end{array}$ & 1.07 & 0.56 & 98.91 & $\begin{array}{l}0.029 \\
0.422\end{array}$ & 二 & 二 & 二 & 二 & 二 & 二 & - \\
\hline & mlt-2 & 49.0 & 4.2 & 12.2 & 0.01 & 2.3 & 9.9 & 0.15 & 7.2 & 11.4 & 2.4 & 0.9 & 0.5 & 100.0 & 0.566 & $\overline{1181}$ & $\overline{2.6}$ & $-\overline{8.1}$ & $\overline{0}$ & $1 \overline{7.8}$ & $0 . \overline{21}$ & $0 . \overline{11}$ \\
\hline & cpx-2 & 49.03 & 1.66 & 4.07 & 0.75 & - & 6.34 & 0.12 & 15.40 & 20.83 & 0.43 & ND & ND & 98.64 & 0.812 & - & - & - & - & - & - & - \\
\hline 157-953C- & & & & & & & & & & & & & & & & & & & & & & \\
\hline $102 \mathrm{R}-1,8-28$ & & & & & & & & & & & & & & & & & & & & & & \\
\hline 1 & $\mathrm{gl}$ & 46.28 & 5.32 & 13.42 & 0.04 & - & 12.37 & 0.18 & 5.30 & 9.80 & 2.85 & 1.46 & 0.76 & 97.78 & 0.433 & $\overline{100}$ & - & $\overline{0}$ & - & - & $\overline{0}$ & $-\overline{0}$ \\
\hline & $\mathrm{mlt}$ & 47.8 & 4.8 & 12.4 & 0.04 & 2.4 & 10.0 & 0.16 & 6.8 & 11.0 & 2.6 & 1.3 & 0.7 & 100.0 & 0.547 & 1182 & 3.9 & -8.2 & 0 & 12.3 & 0.28 & 0.14 \\
\hline & cpx & 49.02 & 1.96 & 3.97 & 0.32 & - & 6.93 & 0.13 & 15.12 & 20.14 & 0.45 & ND & ND & 98.02 & 0.795 & - & - & - & - & - & - & - \\
\hline 3 & gl & 48.04 & 4.69 & 13.11 & 0.05 & - & 12.25 & 0.17 & 5.83 & 9.44 & 2.95 & 1.25 & 0.69 & 98.48 & 0.459 & - & - & - & - & - & - & - \\
\hline 3 & $\begin{array}{l}\text { mit } \\
\text { mlt }\end{array}$ & $\begin{array}{l}49.34 \\
4\end{array}$ & 4.0 & 11.8 & 0.04 & 2.2 & 9.8 & 0.15 & 7.7 & 10.8 & 2.5 & 1.1 & 0.6 & 100.0 & 0.583 & 1217 & $\overline{5.5}$ & $-\overline{7.8}$ & $\overline{0}$ & $1 \overline{14.9}$ & $0 . \overline{27}$ & 0.15 \\
\hline & cpx & 50.89 & 1.34 & 2.57 & 0.57 & - & 6.13 & 0.14 & 16.23 & 19.90 & 0.40 & ND & ND & 98.15 & 0.825 & - & - & - & - & - & - & - \\
\hline 6 & $\begin{array}{l}\mathrm{pl} x \\
\mathrm{gl}\end{array}$ & $\begin{array}{l}50.09 \\
46.00\end{array}$ & $\begin{array}{l}1.34 \\
4.99\end{array}$ & $\begin{array}{r}14.22 \\
\end{array}$ & 0.03 & 二 & $\begin{array}{l}0.19 \\
11.95\end{array}$ & 0.18 & $\begin{array}{r}1.25 \\
5.17\end{array}$ & 10.24 & $\begin{array}{l}.40 \\
2.93\end{array}$ & 1.42 & 0.79 & 97.90 & 0.435 & - & - & 二 & 二 & 二 & 二 & $\bar{z}$ \\
\hline & mlt & 47.2 & 4.7 & 13.7 & 0.03 & 2.4 & 9.8 & 0.17 & 6.1 & 11.1 & 2.8 & 1.3 & 0.7 & 100.0 & 0.527 & $\overline{1156}$ & $\overline{3.0}$ & $-\overline{8.5}$ & $\overline{0}$ & $\overline{7.6}$ & $0 . \overline{29}$ & $0 . \overline{16}$ \\
\hline & cpx & 47.36 & 2.54 & 5.63 & 0.86 & - & 7.41 & 0.13 & 14.23 & 20.12 & 0.45 & ND & ND & 98.71 & 0.774 & - & - & - & - & - & - & - \\
\hline 16 & gl-1 & 46.63 & 4.75 & 13.54 & 0.05 & - & 11.92 & 0.17 & 5.90 & 10.94 & 2.75 & 1.26 & 0.66 & 98.59 & 0.469 & - & - & - & - & - & - & - \\
\hline & mlt-1 & 47.6 & 4.4 & 12.9 & 0.05 & 2.3 & 9.7 & 0.16 & 6.9 & 11.8 & 2.6 & 1.2 & 0.6 & 100.0 & 0.558 & 1177 & 3.0 & -8.3 & 0 & 8.4 & 0.27 & 0.14 \\
\hline & cpx-1 & 48.72 & 2.02 & 4.47 & 0.78 & - & 6.41 & 0.13 & 14.77 & 20.81 & 0.45 & ND & ND & 98.55 & 0.804 & - & - & - & - & - & - & - \\
\hline & gl-2 & 47.14 & 4.77 & 13.62 & 0.06 & - & 11.53 & 0.18 & 5.62 & 10.65 & 2.96 & 1.44 & 0.70 & 98.66 & 0.465 & - & - & - & - & - & - & - \\
\hline & mlt-2 & 48.1 & 4.4 & 12.8 & 0.05 & 2.2 & 9.3 & 0.16 & 6.8 & 11.6 & 2.7 & 1.3 & 0.6 & 100.0 & 0.563 & 1176 & 2.9 & -8.3 & 0 & 9.9 & 0.30 & 0.15 \\
\hline & cpx-2 & 49.49 & 1.75 & 3.68 & 0.71 & - & 6.44 & 0.12 & 15.14 & 20.63 & 0.43 & ND & ND & 98.39 & 0.807 & - & - & - & - & - & - & - \\
\hline 22 & $\mathrm{gl}$ & 47.80 & 5.14 & 13.33 & 0.05 & - & 11.66 & 0.23 & 6.02 & 10.36 & 2.55 & 1.19 & 0.73 & 99.06 & 0.479 & - & - & - & - & - & - & - \\
\hline & mlt & 48.5 & 4.7 & 12.5 & 0.05 & 2.2 & 9.4 & 0.21 & 7.1 & 11.2 & 2.3 & 1.1 & 0.7 & 100.0 & 0.574 & 1186 & 3.6 & -8.1 & 0 & 9.5 & 0.23 & 0.14 \\
\hline & cpx & 49.48 & 1.80 & 3.82 & 0.82 & - & 6.40 & 0.14 & 15.80 & 19.79 & 0.41 & ND & ND & 98.46 & 0.815 & - & - & - & - & - & - & - \\
\hline 29 & $\mathrm{gl}$ & 44.95 & 5.49 & 13.75 & 0.03 & - & 14.36 & 0.23 & 5.00 & 9.99 & 3.17 & 1.35 & 0.68 & 99.00 & 0.383 & - & - & - & - & - & - & - \\
\hline & mlt & 46.3 & 4.7 & 12.2 & 0.03 & 2.8 & 11.3 & 0.20 & 6.8 & 11.3 & 2.7 & 1.2 & $\begin{array}{l}0.60 \\
0.6\end{array}$ & 100.0 & 0.517 & $\overline{1179}$ & 3.9 & $-\overline{8.2}$ & $\overline{0}$ & 15.7 & $0 . \overline{25}$ & $0 . \overline{12}$ \\
\hline & cpx & 47.47 & 2.39 & 5.47 & 0.42 & - & 7.21 & 0.13 & 13.80 & 21.12 & 0.48 & ND & ND & 98.48 & 0.773 & - & - & - & - & - & - & - \\
\hline 30 & $\mathrm{gl}$ & 47.36 & 4.35 & 13.09 & 0.04 & - & 11.75 & 0.19 & 6.29 & 11.05 & 2.64 & 1.16 & 0.57 & 98.50 & 0.488 & - & - & - & - & - & - & - \\
\hline 30 & $\begin{array}{l}\text { mit } \\
\text { mlt }\end{array}$ & 48.4 & 4.0 & 12.3 & 0.04 & $\overline{2.1}$ & 9.5 & 0.17 & 7.5 & 12.1 & 2.4 & 1.1 & 0.5 & 100.0 & 0.583 & $\overline{1193}$ & $\overline{3.1}$ & $-\overline{8.1}$ & $\overline{0}$ & 10.2 & $0 . \overline{27}$ & $0 . \overline{13}$ \\
\hline & cpx & 49.69 & 1.55 & 3.61 & 0.91 & - & 5.85 & 0.13 & 15.46 & 20.60 & 0.39 & ND & ND & 98.19 & 0.825 & - & - & - & - & - & - & - \\
\hline 32 & $\mathrm{gl}$ & 48.71 & 4.89 & 13.66 & 0.03 & - & 11.74 & 0.17 & 5.28 & 9.27 & 2.87 & 1.49 & 0.69 & 98.80 & 0.445 & - & - & - & - & - & - & - \\
\hline & mlt & 49.6 & 4.3 & 12.4 & 0.03 & 2.2 & 9.5 & 0.15 & 7.0 & 10.6 & 2.5 & 1.3 & 0.6 & 100.0 & 0.568 & 1193 & 4.2 & -8.0 & 0 & 13.9 & 0.30 & 0.14 \\
\hline & cpx & 51.03 & 1.48 & 2.56 & 0.45 & - & 6.72 & 0.14 & 16.34 & 19.60 & 0.38 & ND & ND & 98.70 & 0.812 & - & - & - & - & - & - & - \\
\hline 33 & $\mathrm{gl}$ & 46.50 & 4.46 & 12.64 & 0.05 & - & 12.63 & 0.22 & 6.23 & 11.44 & 2.54 & 1.15 & 0.55 & 98.42 & 0.468 & - & - & - & - & - & - & - \\
\hline & mlt & 47.6 & 4.1 & 11.9 & 0.05 & 2.4 & 10.2 & 0.20 & 7.3 & 12.4 & 2.3 & 1.1 & 0.5 & 100.0 & 0.559 & 1181 & 2.2 & -8.2 & 0 & 9.2 & 0.26 & 0.12 \\
\hline & cpx & 49.17 & 2.00 & 4.37 & 0.71 & - & 6.23 & 0.13 & 14.78 & 20.99 & 0.44 & ND & ND & 98.81 & 0.809 & - & - & - & - & - & - & - \\
\hline 34 & $\mathrm{gl}$ & 48.70 & 4.93 & 13.37 & 0.02 & 二 & 10.90 & 0.15 & $\begin{array}{r}1.70 \\
6.02\end{array}$ & 10.32 & 2.54 & 1.20 & 0.66 & 98.81 & 0.496 & 二 & - & 二 & 二 & 二 & - & - \\
\hline & mlt & 49.4 & 4.6 & 12.8 & 0.02 & 2.0 & 8.9 & 0.14 & 6.9 & 11.0 & 2.4 & 1.1 & 0.6 & 100.0 & 0.579 & 1182 & 3.4 & -8.2 & 0 & 7.1 & $0 . \overline{24}$ & 0.13 \\
\hline & cpx & 49.88 & 1.69 & 3.50 & 0.82 & - & 6.35 & 0.14 & 15.85 & 20.05 & 0.39 & ND & ND & 98.69 & 0.817 & - & - & - & - & - & - & - \\
\hline
\end{tabular}


Appendix Table 3 (continued).

\begin{tabular}{|c|c|c|c|c|c|c|c|c|c|c|c|c|c|c|c|c|c|c|c|c|c|c|}
\hline Sample & Phase & $\mathrm{SiO}_{2}$ & $\mathrm{TiO}_{2}$ & $\mathrm{Al}_{2} \mathrm{O}_{3}$ & $\mathrm{Cr}_{2} \mathrm{O}_{3}$ & $\mathrm{Fe}_{2} \mathrm{O}_{3}$ & $\mathrm{FeO}$ & $\mathrm{MnO}$ & $\mathrm{MgO}$ & $\mathrm{CaO}$ & $\mathrm{Na}_{2} \mathrm{O}$ & $\mathrm{K}_{2} \mathrm{O}$ & $\mathrm{P}_{2} \mathrm{O}_{5}$ & Total & $\mathrm{Mg \# ,} \mathrm{Fo}$ & $\mathrm{T}\left({ }^{\circ} \mathrm{C}\right)$ & $\mathrm{P}$ (kbar) & $\lg f_{\mathrm{O} 2}$ & $\mathrm{Ol}_{\text {add }}$ & $\mathrm{Cpx}_{\mathrm{add}}$ & $\mathrm{K}_{2} \mathrm{O} / \mathrm{TiO}_{2}$ & $\mathrm{P}_{2} \mathrm{O}_{5} / \mathrm{TiO}_{2}$ \\
\hline \multicolumn{23}{|l|}{$\begin{array}{l}157-956 \mathrm{~B}- \\
44 \mathrm{R}-3,57-71\end{array}$} \\
\hline & $\mathrm{gl}$ & 47.45 & 5.23 & 13.04 & 0.03 & - & 12.16 & 0.17 & 4.93 & 9.41 & 2.02 & 1.62 & 0.64 & 96.71 & 0.420 & - & - & - & - & - & - & - \\
\hline & mlt & 49.4 & 4.6 & 12.0 & 0.03 & 3.3 & 9.0 & 0.15 & 6.9 & 11.1 & 1.8 & 1.4 & 0.6 & 100.0 & 0.577 & 1159 & 1.2 & -7.5 & 0 & 15.2 & 0.31 & 0.12 \\
\hline & cpx & 49.81 & 1.50 & 2.99 & 0.41 & - & 6.21 & 0.10 & 15.46 & 21.12 & 0.46 & ND & ND & 98.05 & 0.816 & - & - & - & - & - & - & - \\
\hline \multirow[t]{3}{*}{7} & $\mathrm{gl}$ & 48.10 & 4.30 & 14.57 & 0.03 & - & 11.17 & 0.14 & 4.70 & 9.36 & 2.94 & 1.34 & 0.71 & 97.37 & 0.429 & - & - & - & - & - & - & - \\
\hline & mlt & 49.4 & 4.1 & 14.1 & 0.03 & 3.2 & 8.3 & 0.13 & 5.7 & 10.2 & 2.8 & 1.3 & 0.7 & 100.0 & 0.547 & 1141 & 2.2 & -7.7 & 0 & 7.3 & 0.31 & 0.16 \\
\hline & сpx & 49.03 & 1.87 & 4.30 & 0.11 & - & 7.20 & 0.18 & 14.77 & 21.29 & 0.38 & ND & ND & 99.12 & 0.785 & - & - & - & - & - & - & - \\
\hline \multirow[t]{3}{*}{$10 \mathrm{~b}$} & $\mathrm{gl}$ & 48.41 & 3.76 & 14.83 & 0.04 & - & 11.08 & 0.15 & 4.66 & 9.41 & 2.99 & 0.98 & 0.58 & 96.89 & 0.429 & - & - & - & - & - & - & - \\
\hline & $\mathrm{mlt}$ & 50.3 & 3.0 & 12.9 & 0.03 & 2.8 & 8.0 & 0.12 & 7.4 & 11.8 & 2.4 & 0.8 & 0.5 & 100.0 & 0.621 & 1176 & 1.3 & -7.2 & 0 & 21.5 & 0.26 & 0.15 \\
\hline & cpx & 51.31 & 1.02 & 2.70 & 0.66 & - & 5.26 & 0.11 & 16.33 & 21.83 & 0.29 & ND & ND & 99.50 & 0.847 & - & - & - & - & - & - & - \\
\hline \multirow{3}{*}{12} & gl & 52.01 & 3.78 & 12.78 & 0.02 & - & 11.53 & 0.35 & 3.93 & 8.34 & 1.59 & 1.61 & 0.71 & 96.65 & 0.378 & - & - & - & - & - & - & - \\
\hline & mlt & 53.4 & 3.6 & 12.4 & 0.02 & 2.6 & 9.5 & 0.33 & 5.1 & 9.5 & 1.5 & 1.5 & 0.7 & 100.0 & 0.488 & 1123 & $<0.5$ & -8.5 & 0 & 8.9 & 0.43 & 0.19 \\
\hline & cpx & 49.75 & 1.43 & 2.76 & 0.03 & - & 9.04 & 0.37 & 14.75 & 19.60 & 0.44 & ND & ND & 98.16 & 0.744 & - & - & - & - & - & - & - \\
\hline 13 & $\mathrm{gl}$ & 47.29 & 3.96 & 13.58 & 0.04 & - & 10.89 & 0.19 & 5.85 & 10.68 & 2.29 & 1.20 & 0.44 & 96.41 & 0.489 & - & - & - & - & - & - & - \\
\hline & mlt & 49.2 & 3.8 & 13.2 & 0.04 & 3.0 & 8.2 & 0.18 & 7.0 & 11.8 & 2.2 & 1.1 & 0.4 & 100.0 & 0.602 & 1164 & 1.4 & -7.4 & 0 & 8.5 & 0.30 & 0.11 \\
\hline & cpx & 50.24 & 1.04 & 2.93 & 0.68 & - & 5.71 & 0.11 & 15.87 & 21.49 & 0.37 & ND & ND & 98.43 & 0.832 & - & - & - & - & - & - & - \\
\hline 15 & $\mathrm{gl}$ & 52.88 & 3.34 & 14.96 & 0.03 & - & 8.54 & 0.12 & 3.96 & 7.58 & 1.57 & 2.14 & 0.74 & 95.87 & 0.453 & - & - & - & - & - & - & - \\
\hline & $\mathrm{mlt}$ & 54.4 & 2.8 & 13.7 & 0.03 & 2.3 & 6.6 & 0.10 & 6.6 & 9.8 & 1.3 & 1.8 & 0.6 & 100.0 & 0.641 & 1170 & 2.0 & -7.0 & 0 & 18.3 & 0.64 & 0.22 \\
\hline & cpx & 51.03 & 0.99 & 2.21 & 0.65 & - & 4.99 & 0.11 & 16.38 & 21.56 & 0.37 & ND & ND & 98.30 & 0.854 & - & - & - & - & - & - & - \\
\hline 16 & gl-1 & 50.58 & 3.13 & 14.73 & 0.04 & - & 8.86 & 0.12 & 4.85 & 8.81 & 1.95 & 1.72 & 0.73 & 95.52 & 0.494 & - & - & - & - & - & - & - \\
\hline & mlt-1 & 52.8 & 3.2 & 15.1 & 0.04 & 2.6 & 6.9 & 0.12 & 5.5 & 9.5 & 2.0 & 1.7 & 0.7 & 100.0 & 0.585 & 1138 & 1.9 & -7.5 & 0 & 3.2 & 0.55 & 0.23 \\
\hline & gl-2 & 48.39 & $\begin{array}{l}3.2 \\
4.30\end{array}$ & 14.12 & $\begin{array}{l}0.04 \\
0.03\end{array}$ & 2.0 & $\begin{array}{c}0.9 \\
10.30\end{array}$ & $\begin{array}{l}0.12 \\
0.15\end{array}$ & 5.07 & 9.21 & $\begin{array}{l}2.0 \\
2.01\end{array}$ & 1.37 & 0.52 & $\begin{array}{l}900.0 \\
95.46\end{array}$ & 0.467 & 1158 & 1.9 & -1.5 & - & 3.2 & 0.53 & 0.23 \\
\hline & mlt-2 & 50.6 & 4.2 & 14.1 & 0.03 & 2.9 & 7.9 & 0.15 & 6.1 & 10.2 & 2.0 & 1.3 & 0.5 & 100.0 & 0.579 & 1148 & 2.0 & -7.5 & 0 & 6.9 & 0.32 & 0.12 \\
\hline & cpx & 48.93 & 1.76 & 3.83 & 0.37 & - & 6.36 & 0.12 & 15.20 & 20.95 & 0.45 & ND & ND & 97.97 & 0.810 & - & - & - & - & - & - & - \\
\hline 17 & $\mathrm{gl}$ & 47.77 & 4.24 & 14.18 & tr. & - & 11.50 & 0.17 & 4.95 & 9.56 & 3.17 & 1.29 & 0.64 & 97.46 & 0.434 & - & - & - & - & - & - & - \\
\hline & $\mathrm{mlt}$ & 49.1 & 4.0 & 13.6 & tr. & 3.3 & 8.6 & 0.16 & 6.0 & 10.5 & 3.0 & 1.2 & 0.6 & 100.0 & 0.557 & 1158 & 2.9 & -7.5 & 0 & 8.5 & 0.30 & 0.15 \\
\hline & cpx & 50.05 & 1.64 & 3.84 & 0.15 & - & 7.00 & 0.14 & 15.36 & 21.21 & 0.40 & ND & ND & 99.79 & 0.796 & - & - & - & - & - & - & - \\
\hline 157-956B- & & & & & & & & & & & & & & & & & & & & & & \\
\hline $45 \mathrm{R}-3,120-132$ & & & & & & & & & & & & & & & & & & & & & & \\
\hline & $\mathrm{gl}$ & 47.56 & 3.74 & 14.18 & 0.04 & - & 10.59 & 0.18 & 5.07 & 9.87 & 2.04 & 1.21 & 0.50 & 94.98 & 0.461 & - & - & - & - & - & - & - \\
\hline & mlt & 50.3 & 3.2 & $\begin{array}{l}12.9 \\
12.9\end{array}$ & 0.03 & $\overline{2.7}$ & 7.8 & 0.15 & 7.6 & 12.2 & 1.7 & $\begin{array}{l}1.21 \\
1.0\end{array}$ & 0.4 & 100.0 & 0.632 & $\overline{1167}$ & $<\overline{0.5}$ & $-\overline{7.3}$ & $\overline{0}$ & $1 \overline{9.2}$ & $0 . \overline{32}$ & $0 . \overline{13}$ \\
\hline & cpx & 50.92 & 1.01 & 2.65 & 0.68 & - & 4.97 & 0.09 & 16.35 & 21.62 & 0.35 & ND & ND & & 0.854 & - & - & - & - & - & - & \\
\hline 22 & gl & 49.78 & 3.92 & 15.12 & 0.04 & - & 9.96 & 0.16 & 5.15 & 9.14 & 3.40 & 1.41 & 0.76 & 98.85 & 0.480 & - & - & - & - & - & - & - \\
\hline & mlt & 50.9 & 2.8 & 12.0 & 0.03 & 2.2 & 6.8 & 0.11 & 9.0 & 12.1 & 2.4 & 1.0 & 0.6 & 100.0 & 0.701 & 1247 & 5.3 & -6.5 & 0 & 28.8 & 0.36 & 0.20 \\
\hline & cpx & 52.90 & 0.65 & 1.55 & 0.92 & - & 3.68 & 0.08 & 17.52 & 21.99 & 0.29 & ND & ND & 99.59 & 0.895 & - & - & - & - & - & - & - \\
\hline 23 & $\mathrm{gl}$ & 48.65 & 3.69 & 14.63 & 0.03 & - & 10.16 & 0.20 & 5.18 & 10.54 & 2.06 & 1.07 & 0.42 & 96.64 & 0.476 & - & - & - & - & - & - & - \\
\hline & mlt & 50.4 & 3.3 & 13.8 & 0.03 & 1.8 & 8.4 & 0.18 & 6.7 & 12.1 & 1.9 & 1.0 & 0.4 & 100.0 & 0.588 & 1153 & $<0.5$ & -8.4 & 0 & 12.9 & 0.29 & 0.11 \\
\hline & cpx & 49.36 & 1.33 & 3.80 & 0.57 & - & 5.81 & 0.12 & 15.33 & 21.53 & 0.39 & ND & ND & 98.24 & 0.825 & - & - & - & - & - & - & - \\
\hline 26 & $\mathrm{gl}$ & 45.48 & 3.87 & 12.45 & 0.03 & - & 11.58 & 0.20 & 6.37 & 11.44 & 2.52 & 1.14 & 0.44 & 95.52 & 0.495 & - & - & - & - & - & - & - \\
\hline & mlt & 48.2 & 3.5 & 11.6 & 0.03 & 3.0 & 8.6 & 0.18 & 8.1 & 13.2 & 2.3 & 1.0 & 0.4 & 100.0 & 0.628 & 1201 & 2.4 & -7.1 & 0 & 14.1 & 0.29 & 0.11 \\
\hline & $\operatorname{cpx}$ & 50.69 & 1.07 & 2.51 & 0.60 & - & 4.90 & 0.10 & 16.19 & 22.02 & 0.35 & ND & ND & 98.44 & 0.855 & - & - & - & - & - & - & - \\
\hline 37 & $\mathrm{gl}$ & 51.30 & 3.97 & 15.01 & tr. & - & 8.07 & 0.19 & 4.40 & 9.64 & 1.75 & 1.30 & 0.53 & 96.16 & 0.493 & - & - & - & - & - & $\overline{-}$ & - \\
\hline 31 & mlt & 53.0 & 3.5 & $\begin{array}{l}14.01 \\
14.1\end{array}$ & $\begin{array}{l}\text { u. } \\
\text { tr. }\end{array}$ & $\overline{1.4}$ & $\begin{array}{l}0.01 \\
6.9\end{array}$ & 0.17 & $\begin{array}{l}4.40 \\
6.3\end{array}$ & 11.5 & 1.6 & 1.2 & 0.5 & 100.0 & 0.618 & $\overline{1150}$ & $<\overline{0.5}$ & $-\overline{8.5}$ & $\overline{0}$ & $\overline{14.7}$ & $0 . \overline{33}$ & $0 . \overline{13}$ \\
\hline & cpx & 50.95 & 0.96 & 2.48 & 0.44 & - & 5.49 & 0.13 & 16.29 & 21.37 & 0.34 & ND & ND & 98.45 & & - & - & - & & - & - & - \\
\hline $38 \mathrm{a}$ & gl-1 & 46.54 & 4.21 & 13.66 & 0.01 & - & 12.08 & 0.17 & 5.30 & 9.57 & 2.75 & 1.12 & 0.57 & 95.98 & 0.439 & - & - & - & - & - & - & - \\
\hline & mlt-1 & 49.2 & 3.4 & 11.9 & 0.01 & 3.0 & 8.7 & 0.14 & 8.2 & 11.9 & 2.2 & 0.9 & 0.5 & 100.0 & 0.627 & 1207 & 3.4 & -6.9 & 0 & 22.2 & 0.26 & 0.14 \\
\hline & $\mathrm{gl}-2$ & 45.88 & 3.98 & 13.04 & 0.02 & - & 12.71 & 0.17 & 6.22 & 9.15 & 2.67 & 1.07 & 0.56 & 95.47 & 0.466 & - & 0.4 & - & - & & 0.20 & 0.17 \\
\hline & mlt-2 & 48.8 & 3.4 & 11.8 & 0.02 & 3.2 & 9.3 & 0.1 & 8.7 & 11.0 & 2.3 & 0.9 & 0.5 & 100.0 & 0.626 & 1247 & 7.4 & -6.4 & $\overline{0}$ & 18.3 & 0.27 & $0 . \overline{14}$ \\
\hline & $\mathrm{gl}-3$ & 45.19 & 3.88 & 13.03 & 0.03 & - & 12.58 & 0.23 & 5.94 & 9.41 & 2.73 & 1.12 & 0.59 & 94.73 & 0.457 & - & - & - & - & & & \\
\hline & mlt-3 & 48.6 & 3.3 & 11.7 & 0.03 & 3.2 & 9.2 & 0.1 & 8.6 & 11.5 & 2.3 & 1.0 & 0.5 & 100.0 & 0.626 & 1236 & 6.2 & -6.6 & 0 & 19.7 & 0.29 & 0.15 \\
\hline & cpx & 52.19 & 0.93 & 1.91 & 0.30 & - & 5.27 & 0.15 & 17.18 & 21.1 & 0.27 & ND & ND & 99.37 & 0.853 & - & - & - & - & - & - & - \\
\hline $38 \mathrm{~b}$ & $\mathrm{gl}$ & 45.22 & 4.07 & 13.34 & 0.03 & - & 12.62 & 0.21 & 6.03 & 10.42 & 2.74 & 1.04 & 0.60 & 96.32 & 0.460 & - & - & - & - & - & - & - \\
\hline & mlt & 48.1 & 3.3 & 11.6 & 0.02 & 3.1 & 8.9 & 0.17 & 8.7 & 12.6 & 2.2 & 0.8 & 0.5 & 100.0 & 0.636 & 1226 & 4.6 & -6.8 & 0 & 21.8 & 0.26 & 0.15 \\
\hline & cpx & 51.87 & 0.90 & 2.14 & 0.50 & - & 4.88 & 0.09 & 16.79 & 21.96 & 0.30 & ND & ND & 99.43 & 0.860 & - & - & - & - & - & - & - \\
\hline 52 & $\mathrm{gl}$ & 47.24 & 3.80 & $\begin{array}{r}.14 \\
14.49\end{array}$ & 0.03 & $\bar{z}$ & $\begin{array}{r}4.00 \\
11.13\end{array}$ & 0.16 & 5.32 & 9.63 & 2.15 & 1.56 & 0.66 & 96.17 & 0.460 & - & - & 二 & 二 & 二 & 二 & 二 \\
\hline$J 2$ & mlt & $\begin{array}{l}49.34 \\
49.3\end{array}$ & 3.5 & $\begin{array}{l}13.49 \\
13.8\end{array}$ & 0.03 & $\overline{3} .0$ & 8.4 & $\begin{array}{l}0.10 \\
0.15\end{array}$ & $\begin{array}{l}5.32 \\
6.9\end{array}$ & $\begin{array}{l}9.00 \\
11.0\end{array}$ & 2.0 & 1.4 & $\begin{array}{l}0.00 \\
0.6\end{array}$ & $\begin{array}{l}90.11 \\
100.0\end{array}$ & $\begin{array}{l}0.494 \\
0.59\end{array}$ & $\overline{1169}$ & $\overline{2.7}$ & $-\overline{7.2}$ & $\overline{0}$ & $\overline{11.5}$ & $0 . \overline{41}$ & $0 . \overline{17}$ \\
\hline & cpx & 49.45 & 1.39 & 3.47 & 0.49 & - & 5.82 & 0.13 & 15.28 & 21.35 & 0.44 & ND & ND & 97.82 & 0.824 & - & - & - & - & - & - & - \\
\hline 53 & $\mathrm{gl}$ & 45.92 & 3.94 & 13.61 & 0.05 & - & 12.59 & 0.25 & 5.60 & 10.93 & 2.61 & 1.01 & 0.54 & 97.05 & 0.442 & - & - & - & - & - & - & - \\
\hline & mlt & 48.1 & 3.3 & 12.1 & 0.04 & 3.2 & 9.0 & 0.21 & 7.7 & 12.8 & 2.2 & 0.9 & 0.5 & 100.0 & 0.604 & 1179 & 1.2 & -7.3 & 0 & 18.2 & 0.26 & 0.14 \\
\hline & $\operatorname{cpx}$ & 51.61 & 0.98 & 2.50 & 0.46 & - & 5.56 & 0.12 & 16.25 & 22.01 & 0.30 & ND & ND & 99.79 & 0.839 & - & - & - & - & - & - & - \\
\hline 157-956B- & & & & & & & & & & & & & & & & & & & & & & \\
\hline CC, 7-17 & & & & & & - & & & & & & & & & & - & - & - & - & & - & $\ldots$ \\
\hline 57 & $\begin{array}{l}\mathrm{gl} \\
\mathrm{mlt}\end{array}$ & $\begin{array}{l}45.20 \\
46.8\end{array}$ & $\begin{array}{l}4.95 \\
4.8\end{array}$ & $\begin{array}{l}13.49 \\
13.3\end{array}$ & $\begin{array}{l}0.01 \\
0.01\end{array}$ & $\overline{3.8}$ & $\begin{array}{c}12.96 \\
9.7\end{array}$ & $\begin{array}{l}0.21 \\
0.20\end{array}$ & $\begin{array}{l}5.51 \\
6.3\end{array}$ & $\begin{array}{l}10.90 \\
11.7\end{array}$ & $\begin{array}{l}2.15 \\
2.1\end{array}$ & $\begin{array}{l}1.10 \\
1.1\end{array}$ & $\begin{array}{l}0.46 \\
0.4\end{array}$ & $\begin{array}{c}96.95 \\
100.0\end{array}$ & $\begin{array}{l}0.431 \\
0.538\end{array}$ & $\overline{1136}$ & $\overline{0.8}$ & $-\overline{7.8}$ & $\overline{0}$ & $\overline{6.2}$ & $0 . \overline{22}$ & $0 . \overline{09}$ \\
\hline & cpx & 48.50 & 1.96 & 4.44 & 0.14 & - & 7.22 & 0.09 & 14.60 & 21.04 & 0.46 & ND & ND & 98.44 & 0.783 & - & - & - & - & - & - & - \\
\hline
\end{tabular}


Appendix Table 3 (continued).

\begin{tabular}{|c|c|c|c|c|c|c|c|c|c|c|c|c|c|c|c|c|c|c|c|c|c|c|}
\hline Sample & Phase & $\mathrm{SiO}_{2}$ & $\mathrm{TiO}_{2}$ & $\mathrm{Al}_{2} \mathrm{O}_{3}$ & $\mathrm{Cr}_{2} \mathrm{O}_{3}$ & $\mathrm{Fe}_{2} \mathrm{O}_{3}$ & $\mathrm{FeO}$ & $\mathrm{MnO}$ & $\mathrm{MgO}$ & $\mathrm{CaO}$ & $\mathrm{Na}_{2} \mathrm{O}$ & $\mathrm{K}_{2} \mathrm{O}$ & $\mathrm{P}_{2} \mathrm{O}_{5}$ & Total & Mg\#, Fo & $\mathrm{T}\left({ }^{\circ} \mathrm{C}\right)$ & $\mathrm{P}(\mathrm{kbar})$ & $\lg f_{\mathrm{O} 2}$ & $\mathrm{Ol}_{\text {add }}$ & $\mathrm{Cpx}_{\mathrm{add}}$ & $\mathrm{K}_{2} \mathrm{O} / \mathrm{TiO}_{2}$ & $\mathrm{P}_{2} \mathrm{O}_{5} / \mathrm{TiO}_{2}$ \\
\hline \multirow[t]{3}{*}{58} & $\mathrm{gl}$ & 46.59 & 5.21 & 14.21 & 0.03 & - & 13.39 & 0.14 & 4.76 & 9.40 & 2.80 & 1.44 & 0.69 & 98.66 & 0.388 & - & - & - & - & - & - & - \\
\hline & mlt & 47.7 & 4.5 & 12.9 & 0.03 & 3.7 & 9.7 & 0.12 & 6.4 & 10.6 & 2.4 & 1.3 & 0.6 & 100.0 & 0.541 & 1160 & 3.1 & -7.5 & 0 & 13.7 & 0.28 & 0.13 \\
\hline & cpx & 48.34 & 2.22 & 5.28 & 0.42 & - & 7.03 & 0.12 & 14.44 & 21.38 & 0.43 & ND & ND & 99.66 & 0.786 & - & - & - & - & - & - & - \\
\hline \multirow[t]{3}{*}{65} & $\mathrm{gl}$ & 49.71 & 3.21 & 13.43 & 0.03 & - & 9.99 & 0.20 & 5.49 & 9.11 & 2.92 & 1.62 & 0.82 & 96.52 & 0.495 & - & - & 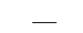 & - & - & - & - \\
\hline & mlt & 51.4 & 3.1 & 13.2 & 0.03 & 2.7 & 7.6 & 0.19 & 6.5 & 10.1 & 2.8 & 1.6 & 0.8 & 100.0 & 0.604 & 1188 & 4.1 & -7.2 & 0 & 7.1 & 0.50 & 0.26 \\
\hline & cpx & 51.12 & 1.26 & 2.92 & 0.27 & - & 5.94 & 0.13 & 16.52 & 21.27 & 0.36 & ND & ND & 99.79 & 0.832 & - & - & - & - & - & - & - \\
\hline \multirow[t]{3}{*}{67} & gl & 51.62 & 4.65 & 14.58 & 0.03 & - & 7.75 & 0.22 & 4.48 & 10.03 & 3.26 & 1.08 & 0.66 & 98.36 & 0.508 & - & - & - & - & - & - & - \\
\hline & mlt & 52.3 & 4.2 & 13.7 & 0.03 & 1.6 & 6.3 & 0.20 & 5.8 & 11.4 & 3.0 & 1.0 & 0.6 & 100.0 & 0.622 & 1143 & $<0.5$ & -8.5 & 0 & 10.9 & 0.23 & 0.14 \\
\hline & cpx & 51.30 & 1.11 & 2.76 & 0.59 & - & 5.03 & 0.08 & 15.96 & 22.45 & 0.28 & ND & ND & 99.56 & 0.850 & - & - & - & - & - & - & - \\
\hline \multirow[t]{3}{*}{73} & $\mathrm{gl}$ & 46.00 & 5.35 & 14.05 & 0.04 & $\overline{-10}$ & 13.45 & 0.24 & 4.53 & 9.52 & 3.16 & 1.52 & 0.81 & 98.66 & 0.375 & $\overline{127}$ & $\overline{27}$ & $\overline{70}$ & - & $\overline{a r}$ & $\overline{00}$ & $\overline{15}$ \\
\hline & mlt & 46.9 & 4.9 & 13.3 & 0.04 & 4.0 & 9.7 & 0.22 & 5.5 & 10.3 & 2.9 & 1.4 & 0.8 & 100.0 & 0.504 & 1137 & 2.7 & -7.9 & 0 & 8.6 & 0.28 & 0.15 \\
\hline & cpx & 47.90 & 2.58 & 4.88 & 0.09 & - & 8.21 & 0.18 & 13.79 & 20.99 & 0.43 & ND & ND & 99.04 & 0.750 & - & - & - & - & - & - & - \\
\hline
\end{tabular}

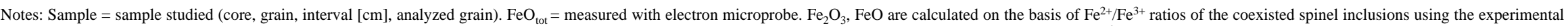
data on spinel (silicate melt equilibrium after Maurel and Maurel, 1982). $\mathrm{Mg} \#=$ atomic ratio $\mathrm{Mg} /\left(\mathrm{Mg}^{+} \mathrm{Fe}_{\mathrm{tot}}\right)$ in glass inclusions and host clinopyroxenes, $\mathrm{Mg} /\left(\mathrm{Mg}{ }^{+} \mathrm{Fe}{ }^{2+}\right)$ in calculated trapped melts, and mol\% Fo in host olivine. $\mathrm{T}\left({ }^{\circ} \mathrm{C}\right)=$ calculated temperature, for glass inclusions represent temperature of melt inclusion quenching and for calculated melts is the temperature of melt entrapment. $\mathrm{Ol}_{\text {add }}$ and $\mathrm{Cpx}_{\text {add }}=\mathrm{amounts}$ of olivine and clinopyroxene (wt $\left.\%\right)$ recrystallized on the inclusions walls and as daughter crystals inside the inclusion volume, which should be added by mass balance calculations to the glass inclusion in order to obtain the composition of trapped melt (see text). gl = glass (i.e., glass inclusions), $\mathrm{mlt}=$ melt (calculated composition of trapped melt), $\mathrm{cpx}=$ host clinopyroxene, and ol $=$ host olivine.$-=$ not calculated, $\mathrm{ND}=$ not determined, and tr. $=$ traces.

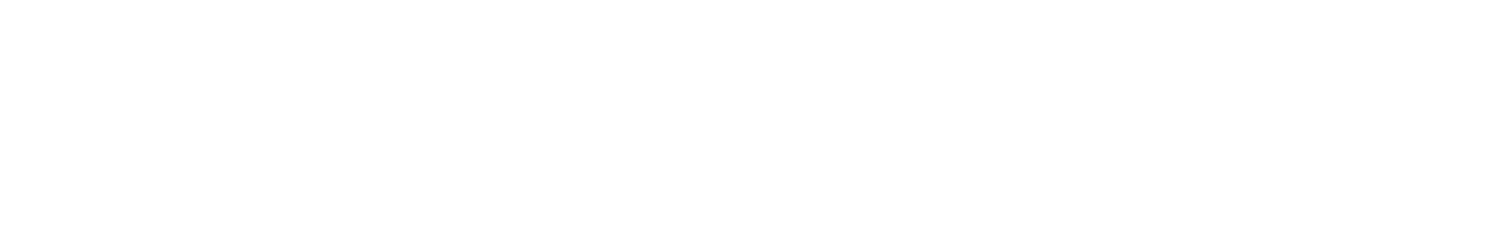

